\title{
Distribution of bats in Northern Cyprus (Chiroptera)
}

\author{
Rozšíření netopýrů na Severním Kypru (Chiroptera)
}

\section{Petr BENDA ${ }^{1,2}$, Lauren SATTERFIELD ${ }^{3}$, Salih GÜCEL ${ }^{4}$, Ivan HORÁČEK ${ }^{2}$, Radek LUČAN $^{2}$, Iris CHARALAMBIDOU ${ }^{5} \&$ Marcel UHRIN $^{6}$}

${ }^{1}$ Department of Zoology, National Museum (Natural History), Václavské nám. 68, CZ-115 79 Praha 1, Czech Republic; petr_benda@nm.cz

2 Department of Zoology, Faculty of Science, Charles University in Prague, Viničná 7, CZ-128 44 Praha 2, Czech Republic

${ }^{3}$ School of Environmental and Forest Sciences, University of Washington, Box 352100, Seattle, WA 98195, U.S.A.

${ }^{4}$ Environmental Research Center, Faculty of Civil and Environmental Engineering, Near East University, Yakın Doğu Bulevard, 99138 Nicosia, Cyprus

${ }^{5}$ Department of Life and Health Sciences, School of Sciences and Engineering, University of Nicosia, 46 Makedonitissas Avenue, CY-1700, Nicosia, Cyprus

${ }^{6}$ Department of Zoology, Institute of Biology and Ecology, P. J. Šafárik University, Šrobárova 2, SK-041 54 Košice, Slovakia

received on 5 December 2018

\begin{abstract}
A complete list of bat records available from Northern Cyprus is presented, based on both limited literature and new records, resulting from a recent field survey conducted mainly in 2018. This review is complemented by distribution maps and summaries of the distributional status of particular species. From the northern part of the island of Cyprus, at least 451 records of 21 bat species are available; viz. Rousettus aegyptiacus (26 record localities), Rhinolophus ferrumequinum (19), $R$. hipposideros (21), $R$. euryale (5), R. mehelyi (1), R. blasii (12), Myotis blythii (4), M. nattereri (10), M. emarginatus (3), M. capaccinii (1), Eptesicus serotinus (5), E. anatolicus (1), Hypsugo savii (6), Pipistrellus pipistrellus (50), P. pygmaeus (9), P. kuhlii (265), Nyctalus leisleri (1), N. lasiopterus (1), Plecotus kolombatovici (3), Miniopterus schreibersii (4), and Tadarida teniotis (5). The number of records increased elevenfold and 1.5 times more bat species were found compared to the last review published in 2007. Seven bat species (Rhinolophus euryale, Myotis emarginatus, Pipistrellus pipistrellus, P. pygmaeus, Nyctalus leisleri, N. lasiopterus, and Miniopterus schreibersii) are reported from Northern Cyprus for the first time; also, $R$. euryale is confirmed for the first time from the whole island. With the exception of Nyctalus noctula, for which doubtful records exist only from Southern Cyprus, the complete known bat fauna of the island was documented in Northern Cyprus. Moreover, three bat species, Rhinolopus mehelyi, Myotis capaccinii and Eptesicus anatolicus, were reported only from the northern part of Cyprus, although the record of $M$. capaccinii is considered as problematic and the occurrence of this species on the island is unlikely. For the first time, a population trend in a bat population is reported in Cyprus; smaller colonies of Rousettus aegyptiacus, even abandonment of roosts, were observed during the recent survey compared to numbers recorded in the mid-2000s.
\end{abstract}

Key words. Distribution, Chiroptera, Cyprus, Middle East, Eastern Mediterranean. 


\section{INTRODUCTION}

The northern part of the island of Cyprus (Northern Cyprus) is a region dominated by the Beşparmak (Kyrenia) Mts. extending to its highest peak at Mount Selvili (Kyparissovouno) at 1,024 m a. s. 1. The mountains consist of a long, narrow, limestone range that runs for approximately $165 \mathrm{~km}$ along the northern coastline of the island and is rich in various karst phenomena. The area covers $3,355 \mathrm{~km}^{2}$, comprising the axis mountain range, hilly and lowland landscapes as well as a long and dramatic coastline corresponding to approximately two-thirds of the coastline length of the whole island.

In comparison with the southern part of Cyprus, the physical geography of the northern part of the island is less diverse and its biota still remains less studied. This is also true of the bat fauna. All main field surveys focused (besides others) on the research of bats, though data was mainly reported from the southern part of the island (BAte 1903, Spitzenberger 1979, Boye et al. 1990, BENDA et al. 2007). Hence, until now the bat fauna of Northern Cyprus comprised only two thirds of the species spectrum known from the whole island and only one fifth of the bat records made on the island (BEnda et al. 2007, AșAn BAydemir 2014; Table 1).

Here we present a review of all available distribution data on bats from Northern Cyprus. A small portion of the data was published in few papers (as reviewed by BENDA et al. 2007); however, most of the data are new, originating from several trips to the whole island from 2009 to 2017, and mainly from a systematic survey of bats in Northern Cyprus in 2018.

The bat survey was conducted as a part of the Caves of Kyrenia Mountains Project, a bicommunal initiative to document caves in the Beşparmak (Kyrenia) Mountain range. The project goals were to conduct research on karst geology and fauna in all documented caves and karst features. However, the bat survey was conducted in the whole area of Northern Cyprus, with a focus on the karst phenomena of the Beşparmak (Kyrenia) Mts. and the adjacent hilly areas.

\section{MATERIAL AND METHODS}

Bats were surveyed by three basic methods of investigation; direct observations at roosts, mist-netting over water bodies and at entrances to potential roosts, and detectoring at foraging grounds. Detectoring was also performed along car-based transects of several tens of kilometres for 1.5 to 2.5 hours (mostly after finishing a netting session, i.e. beginning between 22:00 and 23:00), with the help of the ultrasound detector Batlogger with its microphone fixed with a tripod on the car roof. The detector automatically recorded bat calls together with their geographical positions (WGS84) and current air temperatures. Altogether, 4,413 bat call sequences were recorded during 23 transects in May and October 2018. Bat calls were analysed with the BatExplorer 2.0 software (Elekon AG, Switzerland) using call characteristics known from the respective geographical area (e.g., BENDA et al. 2008, PAPADATOU et al. 2008, own data).

The lists of records of particular species below (arranged in alphabetical and/or chronological order) include, for each item, the following information: name of the locality (each record is primarilly listed by the name of the nearest settlement) [in brackets, number of locality as indicated on the map], and/or description of record site, date, number of recorded bats with indication of their sex, age and physiological condition.

Abbreviations used: $\widehat{\sigma}=$ male, $q=$ female, ad $=$ adult, det. $=$ detected, exam. $=$ examined, ind.$=$ individual, juv = juvenile, $\mathrm{G}=$ pregnant, $\mathrm{L}=$ lactating, net. = netted, obs. = observed, rec. $=$ recorded, $\mathrm{sad}=$ subadult. 
Table 1. Composition of the bat fauna of Northern Cyprus identified in two periods of its survey; $\mathrm{n} 1=$ number of records in Northern Cyprus according to the review by BENDA et al. (2007); \% = percentage of the records in Northern Cyprus from the number of records from the whole island; $\mathrm{n} 2=$ number of records in Northern Cyprus after the recent survey; $\times=$ how many times the number of records in Northern Cyprus is enlarged now vs. that by BENDA et al. (2007); $\mathrm{N}=$ newly documented in Northern Cyprus

Tab. 1. Známé složení netopýří fauny Severního Kypru ve dvou údobích jejího výzkumu; $n 1$ = počet nálezů na Severním Kypru dle přehledu BENDY et al. (2007); \% = procentuální poměr nálezů na Severním Kypru ku počtu nálezů na celém ostrově; $\mathrm{n} 2$ = počet nálezů na Severním Kypru po skončení nového výzkumu; $x=$ kolikrát se nově zvětšil počet nálezů na Severním Kypru oproti publikovanému BENDOU et al. (2007); $\mathrm{N}$ = nově nalezený na Severním Kypru

\begin{tabular}{|c|c|c|c|c|}
\hline \multirow[t]{2}{*}{ species / druh } & \multicolumn{2}{|c|}{2007} & \multicolumn{2}{|c|}{2018} \\
\hline & n1 & $\%$ & $\mathrm{n} 2$ & $\times$ \\
\hline Rousettus aegyptiacus & 11 & 22 & 26 & 2.4 \\
\hline Rhinolophus ferrumequinum & 3 & 25 & 19 & 6.3 \\
\hline Rhinolophus hipposideros & 5 & 28 & 21 & 4.2 \\
\hline Rhinolophus euryale & - & 0 & 5 & $\mathrm{~N}$ \\
\hline Rhinolophus mehelyi & 1 & 100 & 1 & - \\
\hline Rhinolophus blasii & 2 & 18 & 12 & 6.0 \\
\hline Myotis blythii & 1 & 25 & 4 & 4.0 \\
\hline Myotis nattereri & 2 & 18 & 10 & 5.0 \\
\hline Myotis emarginatus & - & 0 & 3 & $\mathrm{~N}$ \\
\hline Myotis capaccinii & 1 & 100 & 1 & - \\
\hline Eptesicus serotinus & 1 & 17 & 5 & 5.0 \\
\hline Eptesicus anatolicus & 1 & 100 & 1 & - \\
\hline Hypsugo savii & 1 & 10 & 6 & 6.0 \\
\hline Pipistrellus pipistrellus & - & 0 & 50 & $\mathrm{~N}$ \\
\hline Pipistrellus pygmaeus & - & 0 & 10 & $\mathrm{~N}$ \\
\hline Pipistrellus kuhlii & 10 & 28 & 265 & 26.5 \\
\hline Nyctalus noctula & - & 0 & - & - \\
\hline Nyctalus leisleri & - & 0 & 1 & $\mathrm{~N}$ \\
\hline Nyctalus lasiopterus & - & 0 & 1 & $\mathrm{~N}$ \\
\hline Plecotus kolombatovici & 1 & 11 & 3 & 3.0 \\
\hline Miniopterus schreibersii & - & 0 & 4 & $\mathrm{~N}$ \\
\hline Tadarida teniotis & 1 & 13 & 5 & 5.0 \\
\hline total species / úhrnem druhů & 14 & 64 & 21 & 1.5 \\
\hline total records / úhrnem nálezů & 41 & 21 & 451 & 11.0 \\
\hline
\end{tabular}

\section{ANNOTATED LIST OF RECORDS}

\section{Rousettus aegyptiacus (Geoffroy, 1810)}

ReCORDS. Original data: Afendrika, ruins of the Asomatos church [1], 17 October 2005: net. 13 $\hat{\delta}$ ad, 4 우 sad/juv (cf. BeNDA et al. 2007, 2011, Hulva et al. 2012); - Afendrika, cave among boulders of a collapsed cavity ca. $250 \mathrm{~m}$ south-east of the Panagia Chrysiotissa church [2], 3 March 2010: obs. 5 roosting inds. (exam. $1 \hat{\delta}$ ad) (cf. BENDA et al. 2011), 17 October 2005: obs. a colony of ca. 100 inds., 12 November 2015: obs. \& exam. 2 $\widehat{\jmath}$ ad roosting, 29 March 2017: obs. \& exam. 1 \& ad G roosting, 18 May \& 10 October 2018: obs. remains of a colony; - Ağırdağ, cleft cave ca. $1 \mathrm{~km}$ west of the village [3], 5-6 April 2005: obs. a colony of at least 12 inds., net. 6 के ad, 1 q ad, 1 + sad (cf. BendA et al. 2007), 2 May 2009: 


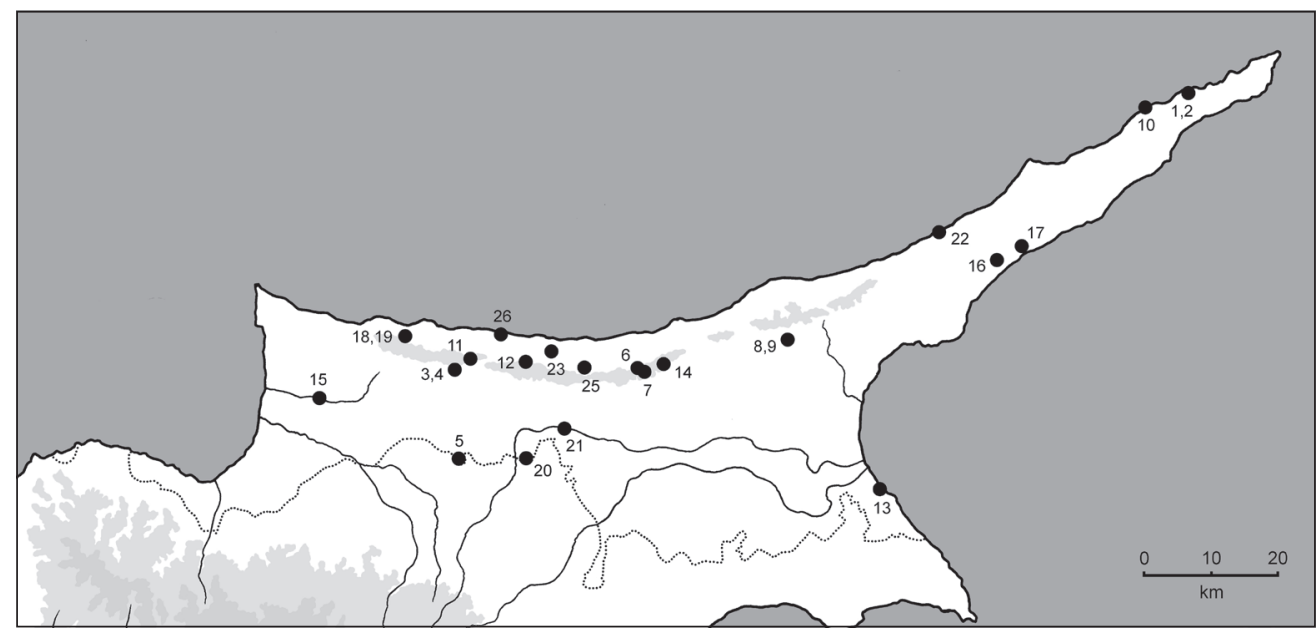

Fig. 1. Records of the Egyptian fruit bat (Rousettus aegyptiacus) in Northern Cyprus; numbers correspond with site numbers in the list of records indicated in brackets; dotted line = border of Northern Cyprus with the buffer zone and Dhekelia Sovereign Base Area, respectively; pale shaded = area above $500 \mathrm{~m} \mathrm{a.} \mathrm{s.} \mathrm{1.;}$ dark shaded $=$ area above $1,000 \mathrm{~m}$ a. $\mathrm{s} .1$.

Obr. 1. Nálezy kaloně egyptského (Rousettus aegyptiacus) na Severním Kypru; čísla odpovídají číslům lokalit uvedeným v hranatých závorkách v přehledu nálezů; tečkovaná čára = hranice Severního Kypru s nárazovým pásmem, resp. územím britské suverenní základny Dhekelia; světle šedě = území nad $500 \mathrm{~m}$ n. m.; tmavě šedě = území nad $1000 \mathrm{~m} \mathrm{n.} \mathrm{m.}$

obs. 2 inds., 5 August 2009: obs. 5 inds. (cf. Benda et al. 2011), 18 May \& 10 October 2018: obs. remains of a colony; - Ağırdağ, Sicak mağara [4], at the cave entrance, 9 July 2015: det. calls; - Alayköy, mine [5], 6 March 2010: obs. a colony of ca. 200 inds. (cf. Benda et al. 2011, Hulva et al. 2012); - Alevkaya, Alevkaya kanyon [6], at the cave entrance, 8 July 2015: det. calls, 22 August 2016: det. calls of numerous inds., 17 May 2018: det. a large colony (invisible, detected noises); - Alevkaya, Küpo mağaras1 [7], forest at the cave entrance, 9 May 2018: obs. 2 flying inds.; - Altınova, İlk gün mağaras1 [8], 19 January 2018: obs. 1 ind.; - Altınova, Sinirli yarasa mağarası [9], 25 August 2016: det. calls of several inds. at the entrance, 26 September 2017: obs. a part of colony, 19 January 2018: obs. a colony of ca. 20 inds., 11 May 2018: obs. a part of colony, 5 inds. observable; - Ayfilon [10], at a palm tree near the basilica ruins, 1 October 2018: obs. 1 foraging ind.; - Aziz Hilaryon kalesi, cave in a cliff wall below the castle [11], 4 April 2005: obs. a colony of ca. 50 inds. (cf. BENDA et al. 2007); - Beylerbeyi, Bellapais Abbey ruins [12], 27 July 2006: obs. places with remnants of repeated feeding (cf. BENDA et al. 2007, 2011), 13 May 2018: obs. a place with feeding remnants; - Gazimağusa, old town [13], ruins of the church of St. George of the Greeks (a side nave and a chapel), 19 April 2005 \& 25 July 2006: obs. places with remnants of repeated feeding (cf. BENDA et al. 2007, 2011), 20 January 2018: obs. places with remnants of repeated feeding; Görneç, Yareselı mağara [14], 23 January 2018: obs. a colony of ca. 30 inds., 9 May 2018: obs. a colony of ca. 20 inds., 4 October 2018: obs. a colony of ca. 40 inds.; - Kalkanll, olive grove reserve [15], above a water reservoir, 16 May 2018: net. 2 우 ad; - Kumyal1, abandoned/destroyed orthodox church [16], 6 May 2018: obs. feeding rests; - Kumyal1, underground quarry ("Kumyalı mağarası I") [17], in the underground room, May 2010: obs. 3 inds., 8 May 2018: obs. a colony of ca. 20 inds., 1 October 2018: obs. 6 inds.; at the largest quarry entrance, 10 May 2018: net. 3 q 9 ad+juv; - Lapta, above a water reservoir

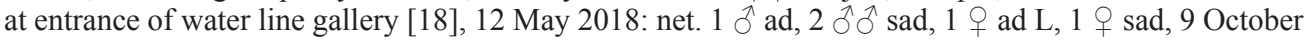


2018: net. 1 ô ad, 1 ô juv, 1 q ad L, 1 q ad+juv; - Lapta, abandoned house in the village [19], 12 May 2018: obs. several roosting inds. during night; - Lefkoşa, downtown [20], 28 January 2018: obs. 1 flying ind.; - Lefkoşa, above a highway at the eastern margin of the town [21], 6 April 2005: obs. 1 flying ind. (cf. BeNDA et al. 2007); - Yedikonuk, Giouti Burnu, a cave in a cliff above road [22], ca. 2 km north-east of the village [= western cave], 17 October 2005: obs. a colony of ca. 800 inds., exam. 3 $\widehat{\partial}$ ad, 3 우 9 ad,

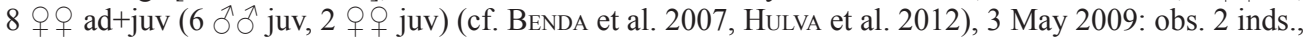
22 February 2010: obs. ca. 20 inds. (cf. BeNDA et al. 2011), 13 November 2015: obs. two colonies in two caves, together of ca. 40 inds., net. 2 ô ad, 29 March 2017: obs. traces of a colony; eastern cave, 21 January \& 8 May 2018: obs. traces of a colony; western cave, 8 May 2018: obs. a colony of ca. 20 inds., western cave, 3 October 2018: obs. a colony of ca. 20 inds. - Published data: near Ayioa Epiktitos [= Agios Epiktitos = Çatalköy] [23] (Bergmans 1994); - [Beylerbeyi,] Bellapais Abbey [12], feeding rests (Spitzenberger 1979); Bellapais, monastery ruins, 8 August 1988: 15 inds. (Opstaele 1990); Bellapais, 1989: destroyed roost (Boye et al. 1990); - Famagusta [= Gazimağusa] [13], obs. 20-50 inds. (SPITZENBERGER 1979); at Famagusta, specimens recorded (Boye et al. 1990); - west of Nicosia [= Lefkoşa] [24], recorded inds. (BoyE et al. 1990); - between Klepini [= Arapköy] and Pentadactylos [= Beşparmak] [25] (Bergmans 1994); - near Kyrenia [= Girne] [26], specimens recorded (Boye et al. 1990).

The Egyptian fruit bat (Rousettus aegyptiacus) was reported as the most frequently recorded bat species in the whole of Cyprus by BENDA et al. (2007) which was also the case for Northern Cyprus (Table 1). However, the present survey showed this species as the third most frequently documented species among the bats of Northern Cyprus with 26 records (Fig. 1) representing only half of the number of localities of the second most frequently documented species, Pipistrellus pipistrellus. Although $R$. aegyptiacus mainly occurs in low situated areas of Northern Cyprus (altitude median 135.5 m a. s. 1.; Fig. 3, Table 2), it also uses high situated localities some of its highest sites are roosts of colonies, e.g. Alevkaya kanyon cave, cleft cave at A $\breve{g} 1 r d a g ̆$, or Yareselı mağara at Görneç, all situated in the upper parts of the Beşparmak (Kyrenia) range (altitude median of roosts $303.0 \mathrm{~m}$, mean $326.7 \mathrm{~m}$ a. s. 1.). The low situated areas of Northern Cyprus thus serve mainly as foraging habitats of this bat, although some roosts also occur in
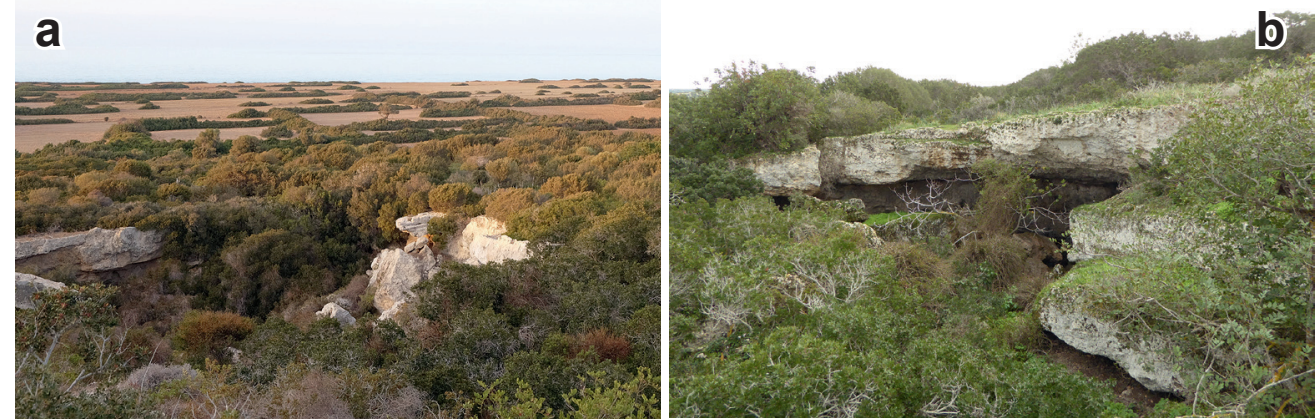

Fig. 2. Collapsed karst cavity ca. $250 \mathrm{~m}$ south-east of the Panagia Chrysiotissa church at Afendrika, Karpaz peninsula, a roost site of four bat species; a - general view of the area, $b$ - entrance to a cave among boulders in the cavity southern side. All photos by Marcel UHRIN.

Obr. 2. Zhroucená krasová dutina ležící zhruba 250 m jihovýchodně od kostela Panagia Chrysiotissa, Afendrika, poloostrov Karpaz, úkryt čtyř druhů netopýrů; a - celkový pohled, b - vstup do jeskyně mezi kamennými bloky na jižní straně dutiny. Všechny fotografie Marcela Uhrina. 
the lowlands (altitude range of roosts $12-662 \mathrm{~m}$ a. s. 1.), while foraging opportunities for this fruit-eating bat at higher altitudes are rare or absent. The altitudinal distribution and habitat use of $R$. aegyptiacus in Northern Cyprus correspond with those in the southern part of the island and also in Lebanon (BENDA et al. 2007, 2016). The territories of Cyprus and Lebanon represent the only areas of dense and abundant distribution of this bat in the Mediterranean arboreal zone and in proximity to the northern margin of the whole distribution range of this bat, comprising the southern coastal areas of Anatolia (see also BENDA et al. 2011, STRACHINIS et al. 2018).

A large proportion of records (44\%) of the Egyptian fruit bats from Northern Cyprus represent findings in roosts. Most roosts represent natural caves (73\%), in two cases the fruit bats were found in artificial underground spaces and once in an abandoned house (in an aboveground room, perhaps serving as a night roost). Numbers of bats found at roosts were generally less during the recent survey compared to 2005-2010 (reported by BENDA et al. 2011). While a colony of 800 bats was found in the cave near Yedikonuk (the largest fruit bat aggregation ever found in Northern Cyprus) and another colony of 100 bats in the cave in the collapsed karst cavity at Afendrika in 2005 (Fig. 2), and 200 bats in a mine at Alayköy in 2010, only several

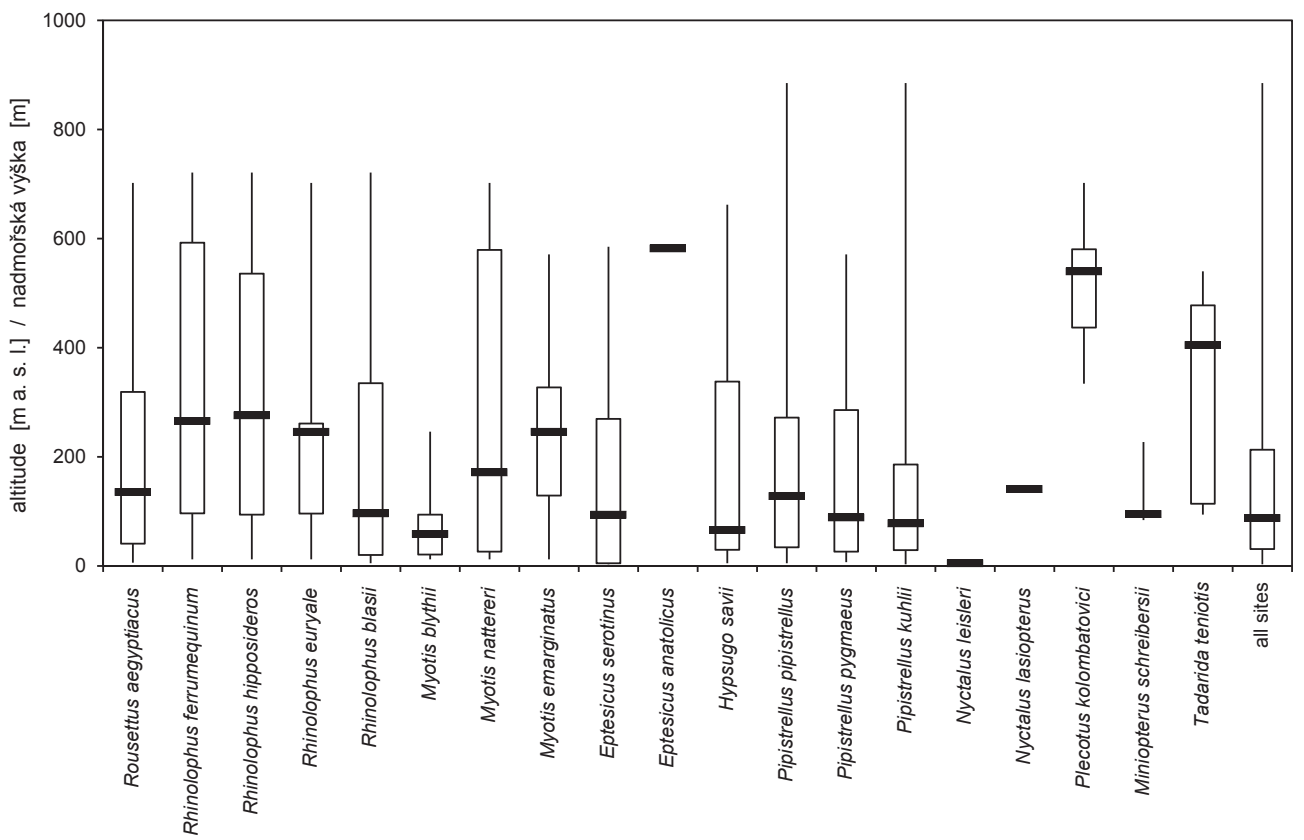

Fig. 3. Comparison of altitudinal distribution of particular bat species in Northern Cyprus (see also Table 2); the boxes represent the range of the first and third quartiles; the vertical lines represent the range of minimum and maximum values; horizontal bold lines represent medians.

Obr. 3. Srovnání výškového rozšíření jednotlivých druhů netopýrů na Severním Kypru (viz také tab. 2); obdélníky představují rozpětí prvního a třetího kvartilu; svislé čáry představují rozpětí minimální a maximální hodnoty; vodorovné silné čárky představují mediany. 
Table 2. Parameters of altitudinal distribution of bats in Northern Cyprus (in metres above sea level; see also Fig. 2); $n=$ number of record sites; $\min , \max =$ mimimum and maximum values of the altitudinal range Tab. 2. Parametry výškového rošíření netopýrů na Severním Kypru (v metrech nad mořem; viz také obr. 2); $\mathrm{n}$ = počet nálezových lokalit; min, max = mimimální a maximální hodnota výškového rozpětí; range = výškové rozpětí; mean = průměr

\begin{tabular}{lrrrrrr}
\hline species / druh & $\mathrm{n}$ & $\min$ & $\max$ & range & mean & median \\
\hline Rousettus aegyptiacus & 26 & 6 & 702 & 696 & 231.6 & 135.5 \\
Rhinolophus ferrumequinum & 19 & 12 & 721 & 709 & 332.7 & 266.0 \\
Rhinolophus hipposideros & 21 & 12 & 721 & 709 & 330.4 & 276.0 \\
Rhinolophus euryale & 5 & 12 & 702 & 690 & 264.4 & 246.0 \\
Rhinolophus mehelyi & 1 & & & & 5.0 & \\
Rhinolophus blasii & 12 & 5 & 721 & 716 & 228.6 & 96.5 \\
Myotis blythii & 4 & 12 & 246 & 234 & 94.0 & 59.0 \\
Myotis nattereri & 10 & 12 & 702 & 690 & 292.4 & 171.5 \\
Myotis emarginatus & 3 & 12 & 571 & 559 & 276.3 & 246.0 \\
Myotis capaccinii & 1 & & & & 5.0 & \\
Eptesicus serotinus & 5 & 3 & 585 & 582 & 203.0 & 94.0 \\
Eptesicus anatolicus & 1 & & & & 582.0 & \\
Hypsugo savii & 6 & 5 & 662 & 657 & 234.7 & 66.0 \\
Pipistrellus pipistrellus & 50 & 5 & 885 & 880 & 208.3 & 128.0 \\
Pipistrellus pygmaeus & 10 & 7 & 571 & 564 & 169.7 & 89.0 \\
Pipistrellus kuhlii & 265 & 3 & 885 & 882 & 136.3 & 78.0 \\
Nyctalus leisleri & 1 & & & & 5.0 & \\
Nyctalus lasiopterus & 1 & & & & 141.0 & \\
Plecotus kolombatovici & 3 & 334 & 702 & 368 & 525.3 & 540.0 \\
Miniopterus schreibersii & 4 & 84 & 227 & 143 & 125.3 & 95.0 \\
Tadarida teniotis & 5 & 94 & 540 & 446 & 331.0 & 405.0 \\
\hline all sites / všechny lokality & 302 & 3 & 885 & 882 & 151.4 & 88.0 \\
\hline
\end{tabular}

tens of individuals at maximum were documented in Northern Cypriot fruit bat roosts between 2010 and 2018; 1-5 bats in Afendrika, 3-20 bats in Kumyalı (Fig. 4), 2-40 bats in Yedikonuk, or 20-40 bats in Yareselı mağara. The cave roost at Ağırdağ was found abandoned during the checks in 2010, 2015, 2017, and 2018, respectively. The same situation was observed at the Afendrika cave in 2018 (three checks), although one fruit bat was still found roosting there in spring 2017 and two in autumn 2015. The reason for such a dramatic decrease in numbers of roosting fruit bats remains to be found as well as whether such a decrease also concerns the Southern Cypriot populations. On the other hand, females carrying nonvolant young and subadult bats of both sexes (along with adult bats) were documented during the survey in 2018, indicating that the populations of Northern Cyprus are still viable to a certain degree. During the recent survey, we did not find any traces of mass or individual killing of $R$. aegyptiacus in its roosts in Northern Cyprus, which was common over the whole island in the past when this bat was considered a serious agricultural pest (see the review by HADJISTERKOTIS 2006).

The lactating females, some of which were carrying nonvolat juveniles, were documented in Northern Cyprus on 10 and 12 May and on 9 and 17 October, respectively, and a pregnant female was found on 29 March. These findings are in accordance with the observations of bimodal 

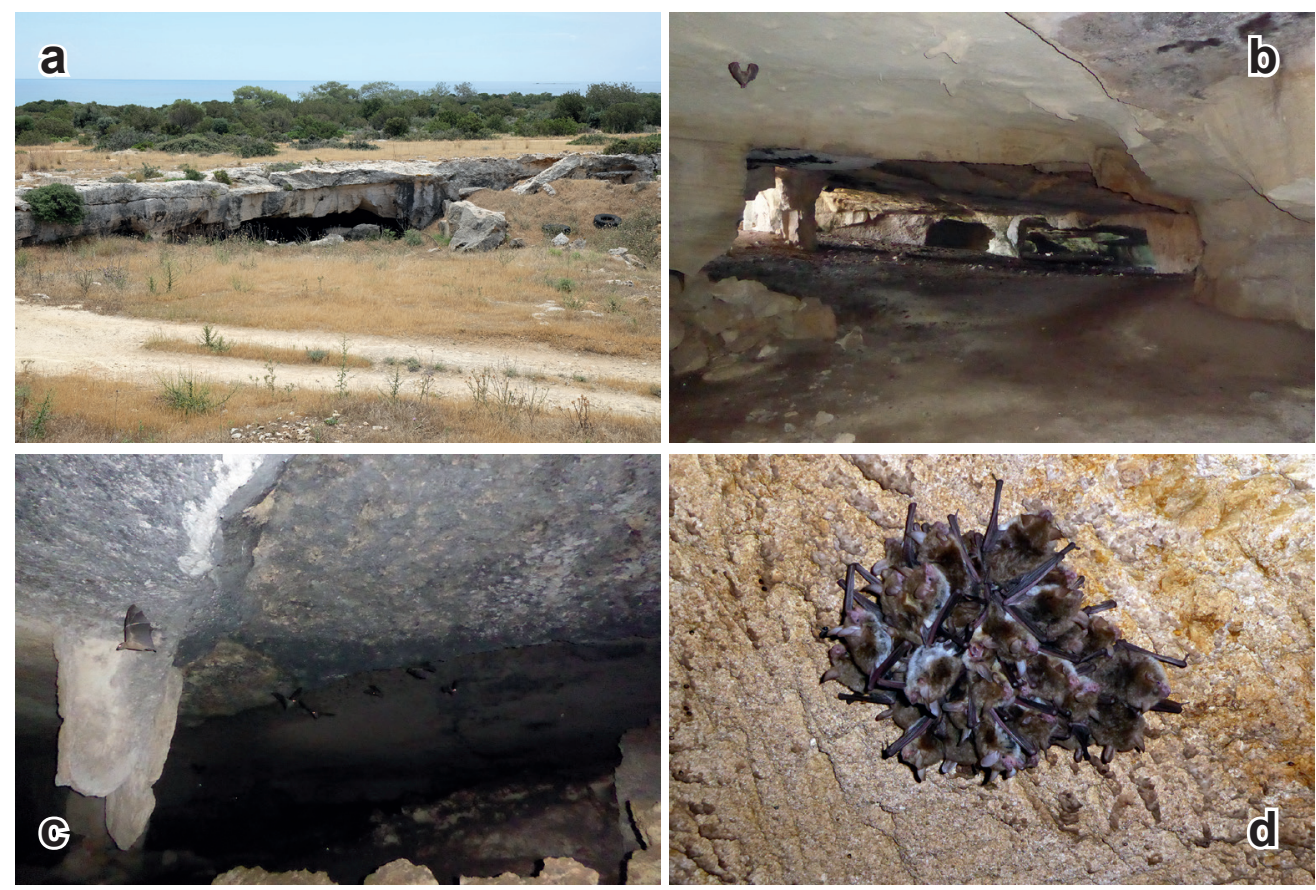

Fig. 4. Historical underground stone quarry ("Kumyalı cave") near Kumyal1, a site of occurrence of nine bat species (and a roost of at least five species); a - view of the largest entrance of the quarry and its situation near the sea shore, $\mathrm{b}$ - view of the inner space of the quarry, $\mathrm{c}$ - a disturbed part of Rousettus aegyptiacus colony inside the quarry, $\mathrm{d}$ - a cluster of 30 individuals of Myotis nattereri discovered in the quarry on 1 Ocober 2018.

Obr. 4. Historický podzemní lom na kámen (tzv. Kumyalská jeskyně) nedaleko vsi Kumyalı, místo výskytu devíti druhů netopýrů (a úkryt nejméně pěti z nich); a - pohled na největší vchod do lomu a jeho poloha blízko mořského pobřeží, b - pohled na vnitřní prostor lomu, c - vyplašená část kolonie Rousettus aegyptiacus, d - shluk 30 kusů Myotis nattereri nalezený v lomu 1. ř́ijna 2018.

polyestry reported for the populations of the Egyptian fruit bat in other Mediterranean parts of its distribution range, including Southern Cyprus, Turkey and the Levant (LuČAN et al. 2014).

\section{Rhinolophus ferrumequinum (Schreber, 1774)}

ReCORDS. Original data: Afendrika, ruins of the Asomatos church [1], 17 October 2005: net. 1 od (cf. BENDA et al. 2007, ŠEVČík et al. 2013); - Afendrika, ruins of the Panagia Chrysiotissa church [2], cellar, 4 May 2009: obs. 1 ind., 1 October 2018: obs. 1 ind. active;-Afendrika, cave among boulders of a collapsed cavity ca. 250 m south-east of the Panagia Chrysiotissa church [3], 13 November 2015: obs. 1 ind. torpid, 29 March 2017: obs. 1 ind., 1 October 2018: obs. \& det. 1 ind. active; - Ağ 11 lar, at a spring ca. 1 km east of the village [4], 11 May 2018: det. \& rec. calls of 1-3 foraging inds.; - Ağırdağ, Sicak mağara [5], at the cave entrance, 20 August 2016: det. calls of several foraging inds.; - Alevkaya, Alevkaya kanyon [6], 
at the cave entrance, 8 July 2015: det. calls, 22 August 2016: det. calls of numerous inds.; - Alevkaya, Alevkaya yol kenarı [7], 28 January 2018: obs. 2 inds. torpid; - Alevkaya, Küpo mağaras1 [8], at the cave entrance, 19 August 2016: det. calls of several foraging inds., 5 May 2018: det. \& rec. calls of 1-3 foraging inds., 2 October 2018: det. \& rec. calls of several foraging inds.; - Alevkaya, Saray mağaras1 [9], at the cave entrance, 24 August 2016: det. calls of several foraging inds.; - Altınova, Sinirli yarasa mağarası [10], at the cave entrance, 5 August 2015: det. calls, 25 August 2016: det. calls of several inds.; - Arapköy, Beşparmak mağara [11], 25 January 2018: obs. 2 inds. torpid; - Çınarlı, İnçirli mağara [12], at the cave entrance, 6 April 2005: det. calls of 1 foraging ind., 17 April 2005: net. 1 ad, 15 October 2005: net. 1 ô ad (cf. Benda et al. 2007, Rossiter et al. 2007, Flanders et al. 2009), 7 May 2018: det. \& rec. calls of 1 foraging ind., 3 October 2018: det. \& rec. calls of several foraging inds.; in the cave, 26 January 2018: obs. 1 ind. torpid; - Değirmenlik, Meraklı pothole [13], at the cave entrance, 21 August 2016: det. calls of 1-2 foraging inds.; - Dipkarpaz, ancient cellar [14], 26 June 2012: obs. 1 ind. (leg. J. Šmíd); - Kalkanl1, olive grove reserve [15], at the "Çoban mağarası" entrance, 16 May 2018: net. 1 ô ad; at a water reservoir, 16 May \& 7 October 2018: det. \& rec. calls of several foraging inds.; - Kumyal1, underground quarry ("Kumyalı mağarası I") [16], at the largest quarry entrance, 10 May 2018: net. 1 o ad, in the underground room, 1 October 2018: obs. \& exam. 19 sad (torpid); underground quarry ("Kumyalı mağarası II"), in the underground room, 1 October 2018: obs. \& exam. 1 o ad (torpid); - Lapta, at the entrance of a water line gallery and at a water reservoir [17], 12 May 2018: det. \& rec. calls of 2 foraging inds.; - Sourp Magar, aboveground room in the monastery ruins [18], 26 July 2006: obs. 1 ind. (cf. BENDA et al. 2007); - Turnalar [19], village, 11 May 2018: det. \& rec. calls of 1-2 foraging inds.

The greater horseshoe bat (Rhinolophus ferrumequinum) is common in Northern Cyprus. Altogether 19 records are available from all parts and altitudes of the country, with the exception of the agricultural landscape of the Mesarya lowland (Fig. 5). The record sites are distributed evenly along the altitudinal range (12-721 m a. s. 1.), with a mean altitude of $333 \mathrm{~m}$ (Table 2, Fig. 3).

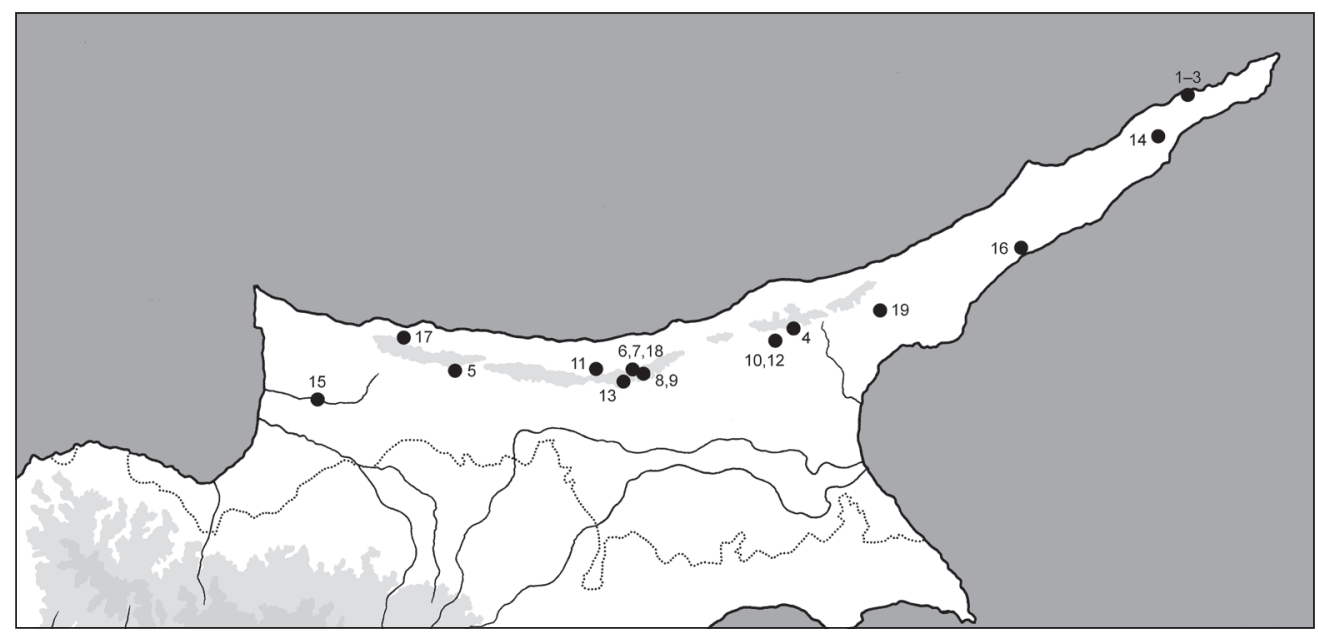

Fig. 5. Records of the greater horseshoe bat (Rhinolophus ferrumequinum) in Northern Cyprus; for the map legend see Fig. 1.

Obr. 5. Nálezy vrápence velkého (Rhinolophus ferrumequinum) na Severním Kypru; vysvětlivky mapy viz obr. 1. 
This indicates that $R$. ferrumequinum occurs regularly across all habitats of the country without any particular preference, similarly to other Mediterranean countries (see e.g. BENDA et al. 2009, 2016). Almost half of the records (47\%) of this bat from Northern Cyprus represent findings in roosts, constituting the largest proportion among all bat species in the country. In all roosts, only single or pairs of individuals were observed, with no signs of any colonies documented. The altitudinal distribution of roosts are in lower altitudes compared to the whole range of records, with a mean altitude of $256 \mathrm{~m}$ a. s. 1., although the three roosts, where hibernating bats were found, lie in high altitudes, including the upper parts of the Beşparmak (Kyrenia) range (altitude mean $499 \mathrm{~m}$ a. s. 1.). The distribution pattern of $R$. ferrumequinum in Northern Cyprus does not differ markedly from that mentioned for the whole island by BENDA et al. (2007).

\section{Rhinolophus hipposideros (Borkhausen, 1797)}

RECORDS. Original data: Afendrika, cave among boulders of a collapsed cavity ca. $250 \mathrm{~m}$ south-east of the Panagia Chrysiotissa church [1], 3 March 2010: obs. 4 roosting inds., 12 November 2015: obs. 1 ind. torpid, 2 inds. active, 13 November 2015: obs. 3 inds. torpid, 28 March 2017: obs. ca. 10 inds. foraging at the cave, 29 March 2017: obs. 2 roosting inds., 21 January 2018: obs. 3 inds. torpid (exam. 1 ad), 6 May 2018: obs. \& det. 1 active ind.; - Ağllar, at a spring ca. $1 \mathrm{~km}$ east of the village [2], 11 May 2018: det. \& rec. calls of 1-2 foraging inds.; - Ağırdağ, at a cleft cave ca. $1 \mathrm{~km}$ west of the village [3], 2 May 2009: det. calls of 1 foraging ind.; - A ğırda ğ, Sicak mağara [4], at the cave entrance, 20 August 2016: det. calls of numerous foraging inds.; - Akantu (Cipro) [= Tatlisu] [5], 12 January 1899: 2 우 우 ad (MSNG 44488, leg. CECCONI); - Alevkaya, Alevkaya kanyon [6], at the cave entrance, 8 July 2015: det. calls, 22 August 2016: det. calls of several inds.; - Alevkaya, Küpo mağaras1 [7], at the cave entrance 3 August 2015: det. calls, 18 August 2016: det. calls of numerous foraging inds., 9 May 2018: det. \& rec. calls of numerous foraging inds., plus obs. \& det. ca. 10 flying inds. in the cave, 2 October 2018: net. 1 ô ad, det. \& rec. calls

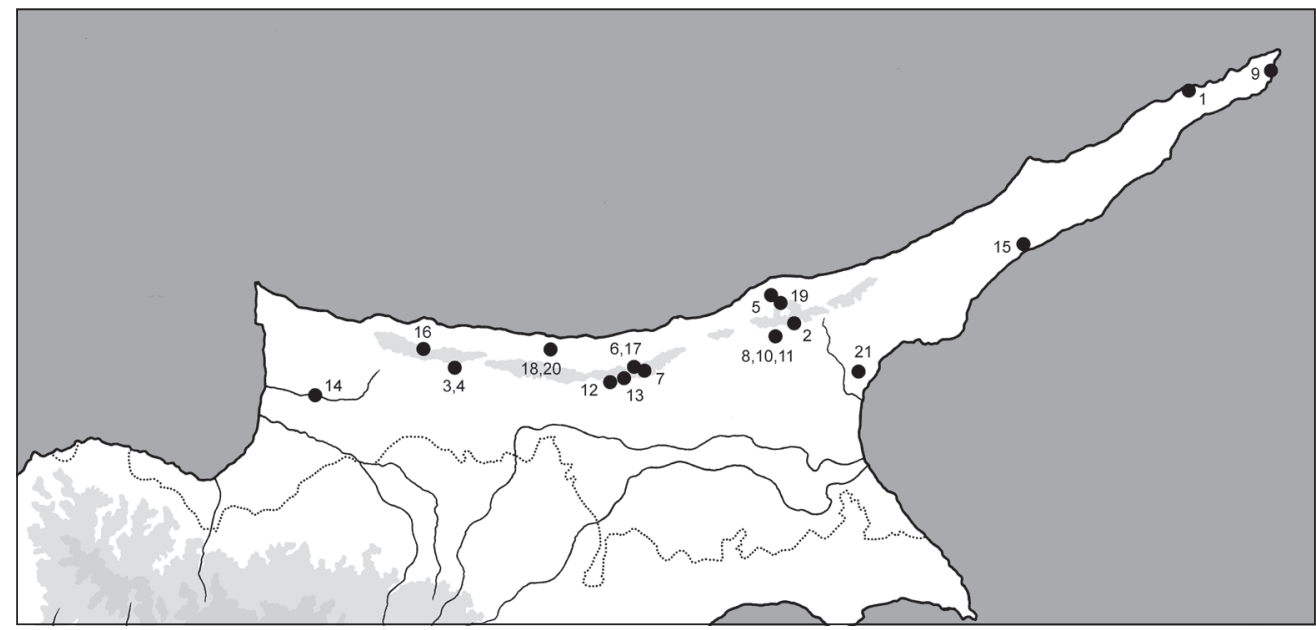

Fig. 6. Records of the lesser horseshoe bat (Rhinolophus hipposideros) in Northern Cyprus; for the map legend see Fig. 1.

Obr. 6. Nálezy vrápence malého (Rhinolophus hipposideros) na Severním Kypru; vysvětlivky mapy viz obr. 1. 

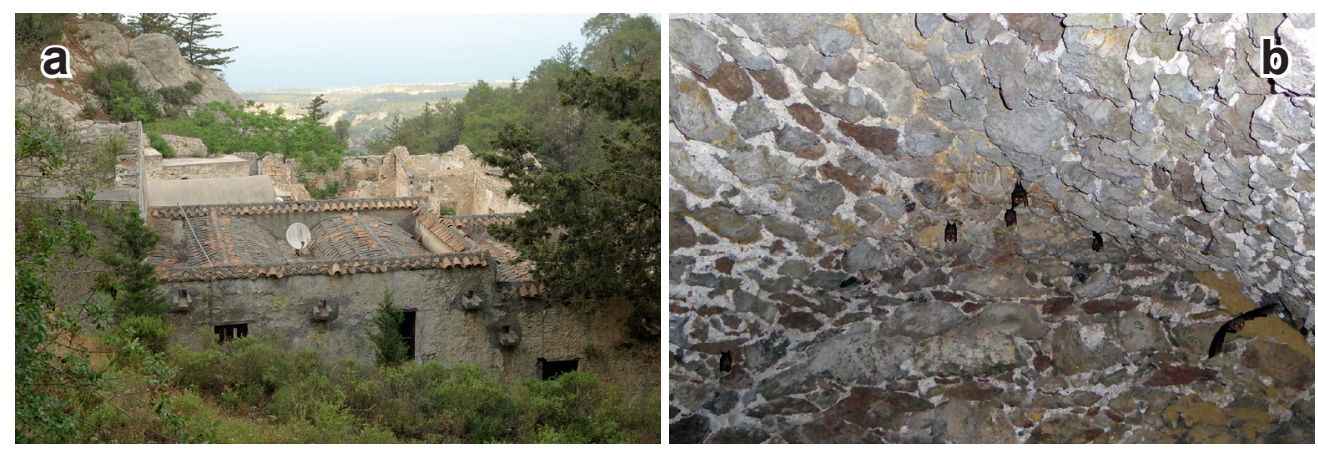

Fig. 7. Abandoned Armenian monastery Sourp Magar on the northern slope of the Beşparmak (Kyrenia) range at ca. $520 \mathrm{~m}$ a. s. 1., a roost of two bat species; a - general view of the monastery surrounded by pine forests, $\mathrm{b}$ - a colony of Rhinolophus hipposideros in a vaulted basement room.

Obr. 7. Opuštěný arménský klášter Sourp Magar na severním svahu hřebene Beşparmak (Kyrenia) ve výšce cca $520 \mathrm{~m} \mathrm{n}$. m., úkryt dvou druhů netopýrů; a - celkový pohled na klášter obklopený borovými lesy, b - kolonie Rhinolophus hipposideros v klenuté přizemní místnosti.

of numerous inds. plus obs. \& det. ca. 15 inds. emerging the cave; - Altınova, Sinirli yarasa mağaras1 [8], at the cave entrance, 5 August 2015: det. calls, 25 August 2016: det. calls of numerous inds.; - Apostolos Andreas manastır1 [9], concrete underground cistern, 27 June 2012: obs. a roosting group (maternity colony) of 8 inds. (leg. J. ŠmíD), 10 May 2018: obs. a group of ca. 5 active inds., 1 October 2018: obs. a group of 9 inds.; - Çınarlı, İnçirli mağara [10], at the cave entrance, 6 April 2005: net. 1 od ad, 1 ô sad, det. 1 ind., 17 April 2005: net. 1 đ ad, det. calls of 2 foraging inds., 15 October 2005: net. 1 o sad (cf. BendA et al. 2007, Dool et al. 2013), 7 May \& 3 October 2018: det. \& rec. calls of numerous inds. emerging the cave and foraging inds., in the cave, 17 April 2005: obs. 1 active ind. (cf. BendA et al. 2007), 5 May 2009: obs. 1 roosting ind., 22 February 2010: obs. 1 roosting ind.; - Çınarl, in an orchard behind the ridge at İnçirli mağara [11], 15 October 2005: det. calls of 1 foraging ind. (cf. BENDA et al. 2007); - Değirmenlik, Başpınar [12], water line gallery, 23 January 2018: obs. 1 ind. torpid; - Değirmenlik, Meraklı pothole [13], at the cave entrance, 21 August 2016: det. calls of 1-2 foraging inds.; - Kalkanl1, olive grove reserve [14], at a water reservoir, 7 October 2018: det. \& rec. calls of 1 foraging ind.; - Kumyal1, at an underground quarry ("Kumyalı mağarası") [15], at the largest quarry entrance, 10 May 2018: det. \& rec. calls of 1-3 foraging inds.; - Malatya, at a mountain spring above the village [16], 6 October 2018: det. \& rec. calls of several foraging inds.; - Sourp Magar [17], monastery ruins, underground gallery, 24 January 2018: obs. 1 torpid ind., 9 May 2018: obs. 1 active ind., 4 October 2018: obs. 2 inds. torpid; vaulted room of the monastery, 31 May 2008: obs. a colony of ca. 15 inds., 9 May 2018: obs. a maternity colony of ca. 15 inds. (ad+juv). - Published data: Agios Epiktitos [= Çatalköy] [18], 15 January 1899: 1 ઈิ ad, MSNF (BENDA et al. 2007); - Lounata Springs [= south-east of Tatlisu] [19], half-cave, 24 March 1973: 1 ind. (Spitzenberger 1979); - Palea Vrysi [= Çatalköy] [20], small fissure cave, 24 March 1973: $5 \widehat{\partial} \widehat{\partial}, 1$ ind. (Spitzenberger 1979); - Trikomo [= İskele] [21], 10 January 1899: 1 ○े ad, MSNF (BendA et al. 2007).

The lesser horseshoe bat (Rhinolophus hipposideros) ranks among the most common bat species in Northern Cyprus, with 21 available records (Fig. 6). The distribution pattern of this bat in the country is almost identical to the previous species (Figs. 3, 5). A slightly lower percentage of the records of $R$. hipposideros than of the previous species represent the roost records (44\%); 

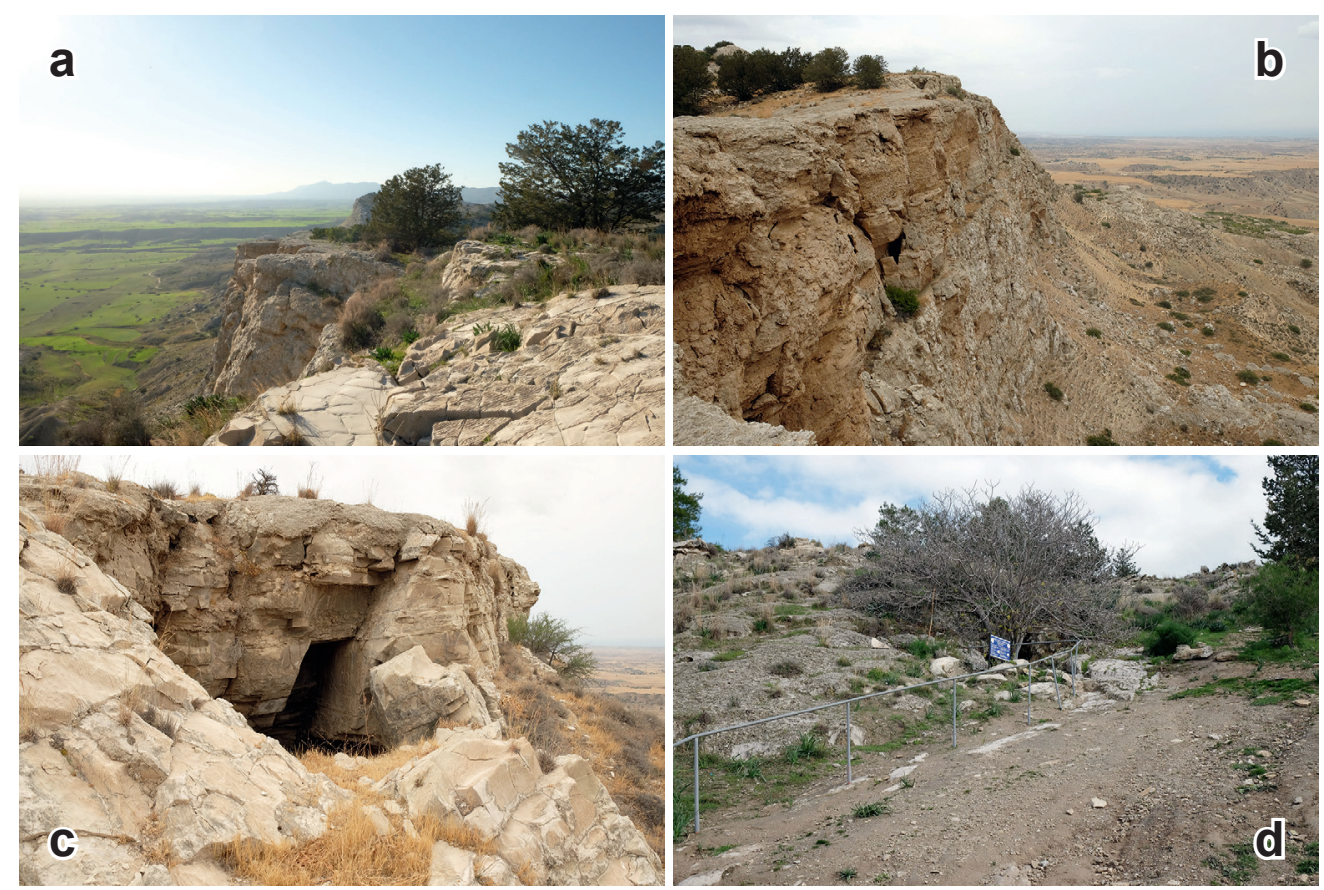

Fig. 8. The gypsum range between Çınarlı and Altınova with sites of bat occurrence; a-view of the northern escarpment of the range, $\mathrm{b}, \mathrm{c}$ - entrance of the Sinirli yarasa cave (a roost of Rousettus aegyptiacus colony) and its location on the range top, $\mathrm{d}$ - entrance of the İnçirli cave near Çınarlı, a record site of eight bat species.

Obr. 8. Sádrovcový hřeben mezi vesnicemi Çınarlı a Altınova s lokalitami výskytu netopýrů; a-pohled na severní eskarpment hřbetu, b, c - vchod do jeskyně Sinirli yarasa (úkrytu kolonie Rousettus aegyptiacus) a jeho poloha na hřebenu, d - vchod do jeskyně İnçirli nedaleko vsi Çınarlı, místo dokumentace výskytu osmi druhů netopýrů.

on the other hand, the checks of these roost sites during different seasons showed a wide variation in roost use. Maternity colonies were found at two sites (concrete cistern at Apostolos Andreas monastery and a vaulted room in the Sourp Magar monastery ruins (Fig. 7), both artificial structures). At five natural caves, roosting individuals were observed during daytime in the non-hibernation period, while at four sites (two natural caves and two artificial spaces) hibernating bats were found. Some roosts were documented to be both summer roosts and hibernacula (Afendrika cave, İnçirli cave, Sourp Magar monastery; Figs. 2, 7, 8). At twelve sites, foraging bats were recorded, by detection of their echolocation calls or by mist-netting. The altitudinal distribution of roost sites follows the distribution of all records and does not show any remarkable shift (the altitude median is $261 \mathrm{~m}$ a. s. 1.). Similarly as the previous species, $R$. hipposideros occurs regularly across all parts and altitudes of the country and represents a universal Mediterranean bat. Old museum specimens from three sites of Northern Cyprus were found in two Italian museum collections and complement the list of records from the country 
(MSNF - Natural History Museum La Specola, Florence, and MSNG - Civil Natural History Museum Giacomo Doria, Genoa).

\section{Rhinolophus euryale Blasius, 1853}

ReCORDS. Original data: Ağıllar, at a spring ca. $1 \mathrm{~km}$ east of the village [1], 11 May 2018: det. \& rec. calls of several foraging inds.; - Alevkaya, Küpo mağaras1 [2], at the cave entrance, 2 October 2018: det. $\&$ rec. calls of 1 foraging ind.; - Çınarlı, İnçirli mağara [3], at the cave entrance, 3 October 2018: det. $\&$ rec. calls of several inds.; - Kumyalı, underground quarry ("Kumyalı mağarası II") [4], at the quarry entrance, 10 May 2018: det. \& rec. calls. of 1 foraging ind.; - Lapta, water line gallery [5], 27 September 2017: obs. a colony of several tens of inds. of medium-sized Rhinolophus sp., 24 January 2018: found remains of a colony, exam. 1 mummy, 13 May 2018: obs. a colony of ca. 50 inds.; at the gallery entrance, 12 May 2018: net. 2 아 ad G, 1 s sad, det. \& rec. calls of numerous foraging inds.

The Mediterranean horseshoe bat (Rhinolophus euryale) is reported here for the frst time, not only from Northern Cyprus but also from the whole island of Cyprus. Two previous reports of R. euryale from Cyprus (THEODOR 1967, Boye et al. 1990), were considered uncertain and doubtful concerning the correct species identification (for details see BENDA et al. 2007). The first indisputable specimen of the Mediterranean horseshoe bat in Cyprus was found among remnants of a bat colony in the water line gallery in Lapta in January 2018, when no living bat was observed at the site (Fig. 9). According to the identified remains, the Lapta colony was a mixture composed of two medium-sized horseshoe bats, $R$. euryale and $R$. blasii. Three additional individuals of $R$. euryale (including two pregnant females) were netted at this site in May 2018, when a colony of 50 medium-sized horsehoe bats was observed inside the gallery (most probably composed of the two above mentioned medium sized Rhinolophus species; interestingly, only $R$. blasii was observed at the site in October 2018). The previous report of $R$. euryale from the southern part of Cyprus by Boye et al. (1990) now seems to be more pro-
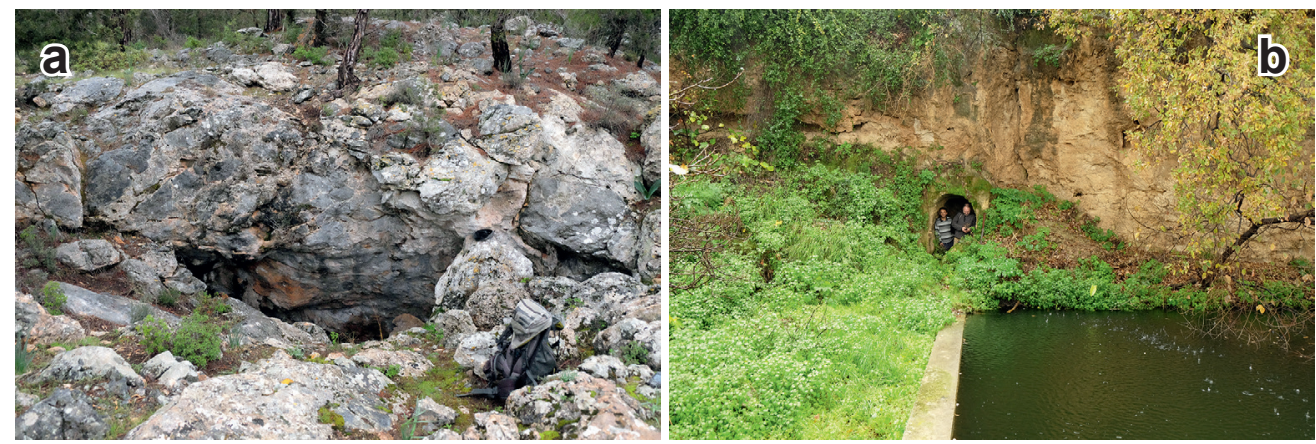

Fig. 9. Two sites of netting at underground bat roosts in Northern Cyprus, eight bat species were found to roost and/or forage at each of them; a - entrance to the Küpo cave near Alevkaya in a forest on the top of the Beşparmak range at ca. $700 \mathrm{~m}$ a. s. 1., b - a water reservoir at an entrance to a water line gallery in the town of Lapta.

Obr. 9. Dvě lokality odchytu do sítí u vstupů do podzemních úkrytů netopýrů na Severním Kypru - na každé bylo dokumentováno osm druhů netopýrů; a - vchod do jeskyně Küpo u Alevkayi v lese na hřebeni Beşparmak v nadmořské výšce asi 700 m, b - vodní nádrž a vchod do vodovodní štoly ve městě Lapta. 


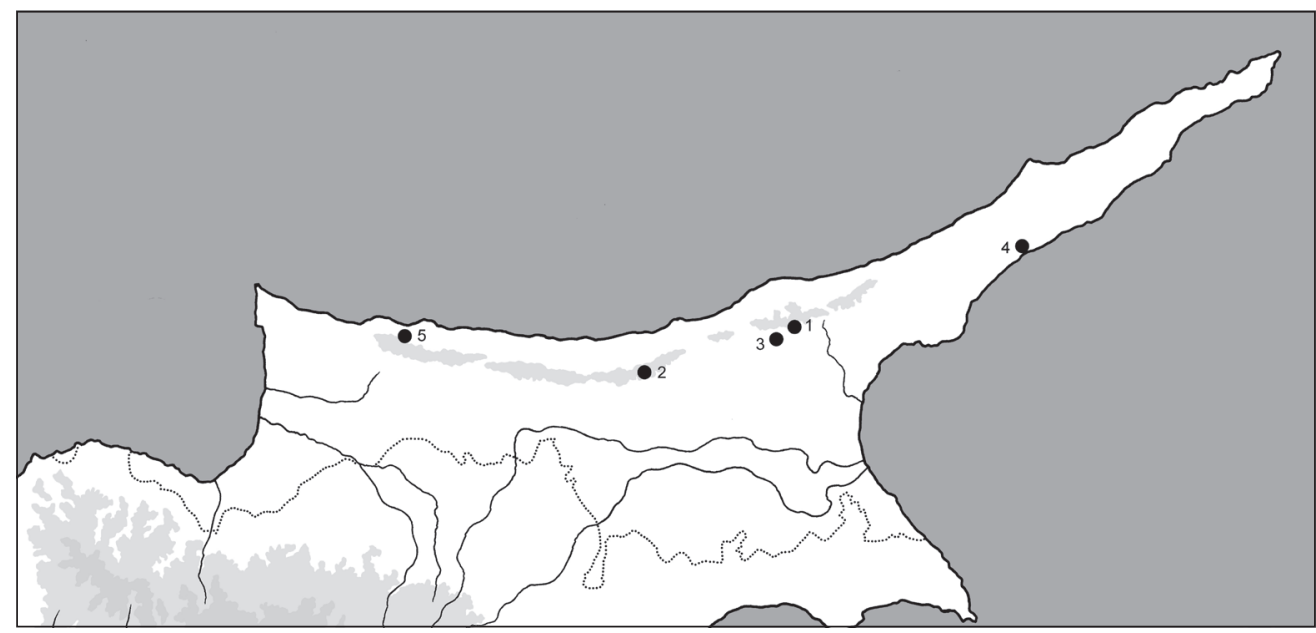

Fig. 10. Records of the Mediterranean horseshoe bat (Rhinolophus euryale) in Northern Cyprus; for the map legend see Fig. 1.

Obr. 10. Nálezy vrápence středozemského (Rhinolophus euryale) na Severním Kypru; vysvětlivky mapy viz obr. 1.

bable. Besides the direct examinations of individuals at their roost, sequences of echolocation calls of $R$. euryale were recorded at four other sites of Northern Cyprus. Most of the localities $(80 \%)$ of this bat are underground roosts and the areas around the entrances to them (two natural caves and two artificial spaces). Despite the limited number of records (Fig. 10), the altitudinal distribution of $R$. euryale in Northern Cyprus (and thus in the whole of Cyprus as well) is similarly wide as in the two widespread horseshoe bat species, Rhinolophus ferrumequinum and $R$. hipposideros (Table 2).

\section{Rhinolophus mehelyi Matschie, 1901}

Record. Published data: Kyrenia [= Girne], 1 ind. (Felten et al. 1977, cf. Kahmann \& ÇaĞLar 1959, 1960).

Only one record of Mehelyi's horseshoe bat (Rhinolophus mehelyi) was reported from Cyprus, based on a specimen originating from Girne (FELTEN et al. 1977); hence, this Northern Cypriot record remains the only finding of this bat available from the whole island. No new record of $R$. mehelyi was made in Cyprus despite a rather intensive survey in the last years (see also BENDA et al. 2007). On the other hand, this species belongs to the rarest bats in its whole distribution range, see e.g. Harrison \& Bates (1991), Benda \& HoráčeK (1998) and Benda et al. (2006) concerning its patchy occurrence in the Middle East.

\section{Rhinolophus blasii Peters, 1866}

RECORDS. Original data: Afendrika, cave among boulders of a collapsed cavity ca. $250 \mathrm{~m}$ south-east of the Panagia Chrysiotissa church [1], 6 May 2018: obs. \& det. 1 active ind.; - Afendrika, ruins of the Panagia 
Chrysiotissa church [2], cellar, 20 January 2018: obs. 2 roosting inds., 6 May 2018: obs. 1 roosting ind.; - Ağırdağ, Sicak mağara [3], at the cave entrance, 20 August 2016: det. calls of several foraging inds.; Altınova, Sinirli yarasa mağaras1 [4], at the cave entrance, 25 August 2016: det. calls of numerous inds.; - Çınarlı, İnçirli mağara [5], at the cave entrance, 7 May 2018: det. \& rec. calls of 1 ind.; - Değirmenlik, Meraklı pothole [6], at the cave entrance, 13 July 2015: det. calls; - Kaleburnu, Kastros tomb [7], 6 May 2018: obs. \& det. calls of 1 active ind.; - Kumyal1, underground quarry ("Kumyalı mağarası II") [8], in the underground room, 1 October 2018: obs. \& exam. 1 + ad; - Lapta, water line gallery [9], 27 September 2017: obs. a colony of several tens of inds. of medium-sized Rhinolophus sp., 24 January 2018: found remains of a colony, exam. 1 mummy; at the gallery entrance, 12 May 2018: det. \& rec. calls of numerous foraging inds., 9 October 2018: net. 1 ad, 1 sad, 2 우 ad, det. \& rec. calls of numerous inds.; - Malatya, at a mountain spring above the village [10], 6 October 2018: det. \& rec. calls of 1 foraging ind. - Published data: Famagusta [= Gazimağusa] [11], 1875: 1 + ad (BENDA et al. 2007); - Kyrenia [= Girne] [12], 1 ind. (Felten et al. 1977).

Although Blasius' horseshoe bat (Rhinolophus blasii) ranks among the medium frequent bats of Northern Cyprus, it represents the most common species of the medium-sized horsehoe bats - altogether twelve records are available covering most of the country area (Fig. 11). Similarly as in the southern part of the island (BENDA et al. 2007), the distribution of $R$. blasii in Northern Cyprus has a wide range, but with a preference for low situated areas (Table 2, Fig. 3). This preference is most apparent when only roosts of this species are considered - the altitudinal range of the five known roost sites is $12-97 \mathrm{~m}$ a. $\mathrm{s}$. 1 . (median $38 \mathrm{~m}$, mean $53 \mathrm{~m}$ a. s. 1.). Thus, it seems that $R$. blasii uses the upper situated areas of Northern Cyprus rather as foraging grounds. Most of the available roost sites represent artificial underground spaces of various primary function (ancient cellar, ancient tomb, ancient water gallery, underground quarry), plus one natural cave. The distribution pattern of $R$. blasii in Northern Cyprus is very similar to that in southern Turkey and the Levant (BENDA \& HorÁČEK 1998, BENDA et al. 2006, 2010, 2016).

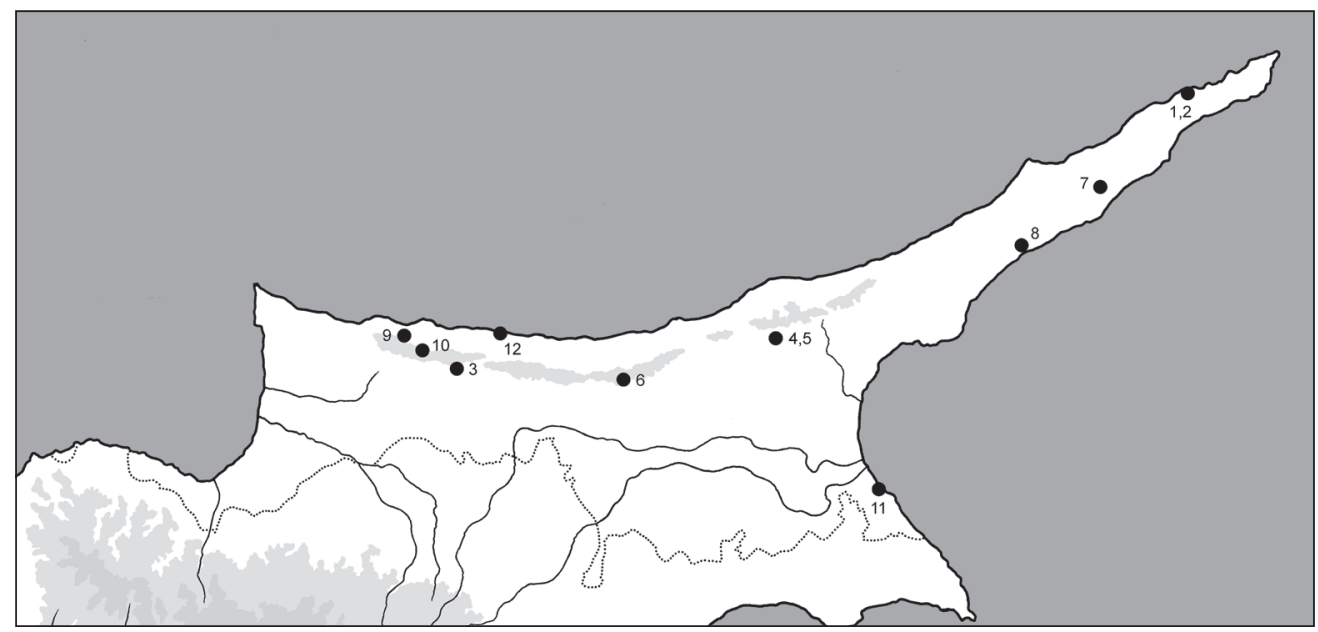

Fig. 11. Records of Blasius' horseshoe bat (Rhinolophus blasii) in Northern Cyprus; for the map legend see Fig. 1.

Obr. 11. Nálezy vrápence Blasiova (Rhinolophus blasii) na Severním Kypru; vysvětlivky mapy viz obr. 1. 


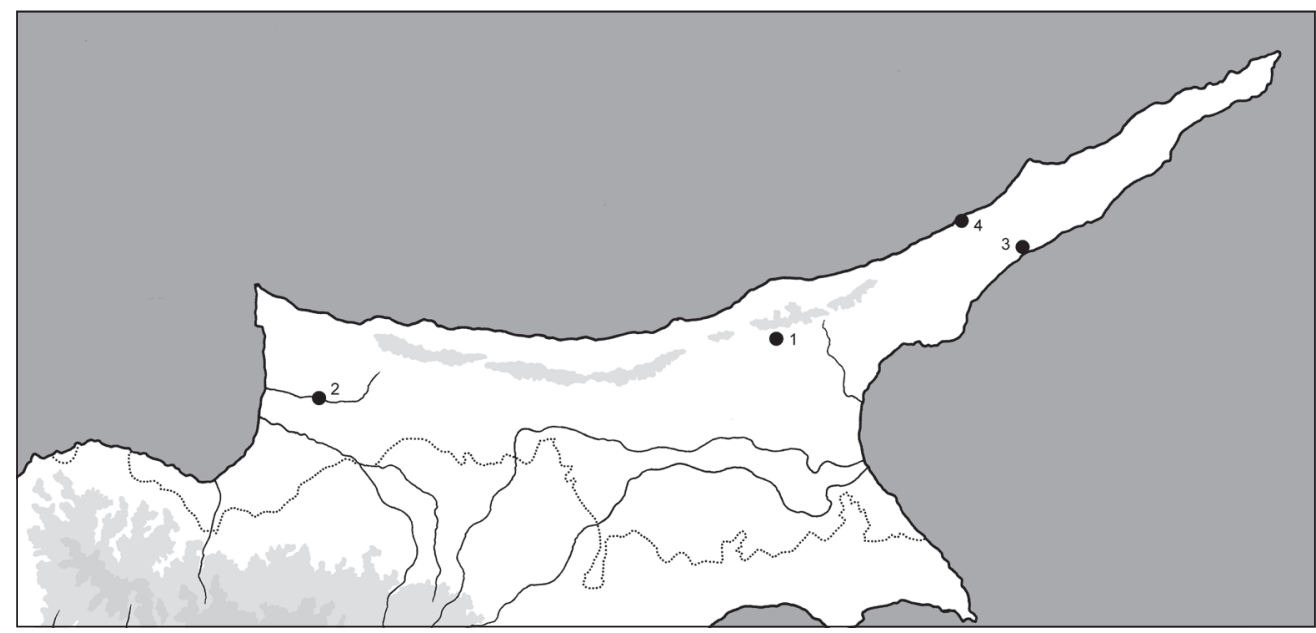

Fig. 12. Records of the lesser mouse-eared bat (Myotis blythii) in Northern Cyprus; for the map legend see Fig. 1.

Obr. 12. Nálezy netopýra ostrouchého (Myotis blythii) na Severním Kypru; vysvětlivky mapy viz obr. 1.

\section{Myotis blythii (Tomes, 1857)}

RECORDS. Original data: Çınarlı, İnçirli mağara [1], at the cave entrance, 17 April 2005: net. $1 \delta$ ad (cf. BENDA et al. 2007); - Kalkanl, olive grove reserve [2], at a water reservoir, 16 May 2018: det. \& rec. calls of 1-2 foraging inds., 7 October 2018: det. \& rec. calls of 1-2 foraging inds.; - Kumyal1, underground quarry ("Kumyalı mağarası I") [3], in the underground room, 1 October 2018: obs. \& det. calls of 1 active ind.; - Yedikonuk, Giouti Burnu, at a cliff above road [4] ca. $5 \mathrm{~km}$ north-east of the village, 4 October 2018: det. \& rec. calls of 1 foraging ind.

The lesser mouse-eared bat (Myotis blythii) represents a rather rare bat species in Cyprus. BENDA et al. (2007) summarised only four records from the whole island, including one from Northern Cyprus. This limited list is complemented here by three new records, including one finding in a roost (Fig. 12). Although in Southern Cyprus M. blythii was recorded in a wide range of altitudes (ca. 120-1500 m a. s. 1.), in Northern Cyprus it may be considered as the most lowland species, with records originating from 12-246 $\mathrm{m}$ a. s. 1. and the smallest altitude median among Northern Cypriot bats (Table 2, Fig. 3). The scarcity of M. blythii records in Cyprus, demonstrated again by the recent survey, is rather surprising in light of the common occurrence of this bat along the southern Anatolian and Levantine coasts (BENDA \& HORÁČEK 1998, BENDA et al. 2006, 2016), or even in comparison with the situation in Crete, where $M$. blythii is the fifth most frequently recorded bat species of 17 species in total (BENDA et al. 2009).

\section{Myotis nattereri (Kuhl, 1817)}

RECORDS. Original data: Afendrika, at ruins of the Asomatos church [1], 6 May 2018: det. \& rec. calls of 1 foraging ind.; - Alevkaya, Küpo mağaras1 [2], at the cave entrance, 2 October 2018: obs. \& det. calls of 1 foraging ind.; - Ayfilon, ancient tomb ca. 1 km south-west of the basilica ruins [3], 10 May 2018: obs. 
1 roosting ind.; - Aziz Hilaryon kalesi [4], corridor to the Byzantine church, in the vault fissure, 22 January 2018: obs. 1 ind. torpid; - Çınarlı, İçcirli mağara [5], at the cave entrance, 6 April 2005: net. 3 우 ad G, 17 April 2005: net. 4 우 ad, 15 October 2005: net. 1 s sad, 1 q sad, det. 1 ind. (cf. Benda et al. 2007, 2010), 7 May 2018: net. 1 ad L, 2 $q$ juv; - Kalkanl1, olive grove reserve [6], above water reservoir and at the "Çoban mağarası" entrance, 16 May 2018: net. 1 और ad, 4 ô juv, 11 우 $ᄋ$ ad, 2 우 0 juv, 1 ind., det. \& rec. calls of 1 foraging ind., 7 October 2018: net. 2 万ै ad, 4 우 ad, 3 우 sad; - Kantara, Kantara kalesi [7], courtyard, 16 October 2005: net. 1 ad (cf. Benda et al. 2007); - Kumyal1, underground quarry ("Kumyalı mağarası I") [8], at the largest quarry entrance, 10 May 2018: net. 1 q ad, 1 juv; underground quarry ("Kumyalı mağarası II"), in the underground room, 1 October 2018: obs. a cluster of 30 inds. semi-torpid; - Malatya, at a mountain spring above the village [9], 18 May 2018: net. 1 ad, $1 \delta \mathrm{sad}, 3$ $9+q$ ad, det. calls of several foraging inds., 6 October 2018: net. $1 \hat{\sigma}$ ad, det. calls of several foraging inds.; - Sadrazamköy [10], at a water reservoir next to a beach resort, 13 May 2018: det. \& rec. calls of 1 foraging ind.

Natterer's bat (Myotis nattereri) belongs to the medium frequent bats of Northern Cyprus (Table 1). Altogether, ten sites of its occurrence were recorded throughout the country, which cover all areas and altitudes (Fig. 13), with the exception of the agricultural landscape of the Mesarya lowland. The records of $M$. nattereri are distributed more or less evenly across the whole altitudinal range, covering $690 \mathrm{~m}$ (Table 2, Fig. 3). This bat was exceptionally frequently recorded at its probable roosts or even inside the roosts (contrary to the previous result by BENDA et al. 2007, when foraging bats significantly prevailed over the roost records). In three cases (İnçirli cave, Çoban quarry, Kumyalı quarry; Figs. 4, 8, 26) the roost records comprise maternity colonies, in the Kumyalı quarry also a cluster aggregation of 30 bats was found in autumn (Fig. 4d). Although one of the roosts was found at a high altitude (635 $\mathrm{m}$ a s 1 . - a hibernating individual in the Aziz Hilaryon castle), most of the roosts were situated in low parts of Northern Cyprus (altitude median $97 \mathrm{~m}$ a. s. 1.). The types of roosts used by M. nattereri

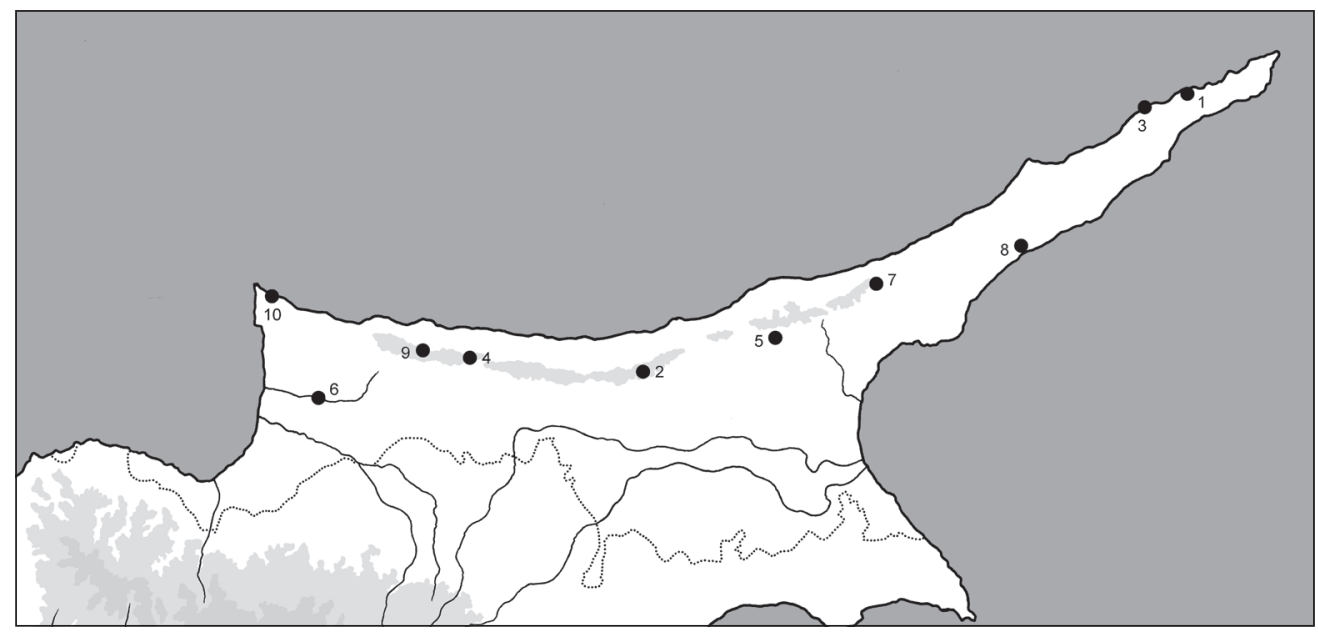

Fig. 13. Records of Natterer's bat (Myotis nattereri) in Northern Cyprus; for the map legend see Fig. 1. Obr. 13. Nálezy netopýra řasnatého (Myotis nattereri) na Severním Kypru; vysvětlivky mapy viz obr. 1. 


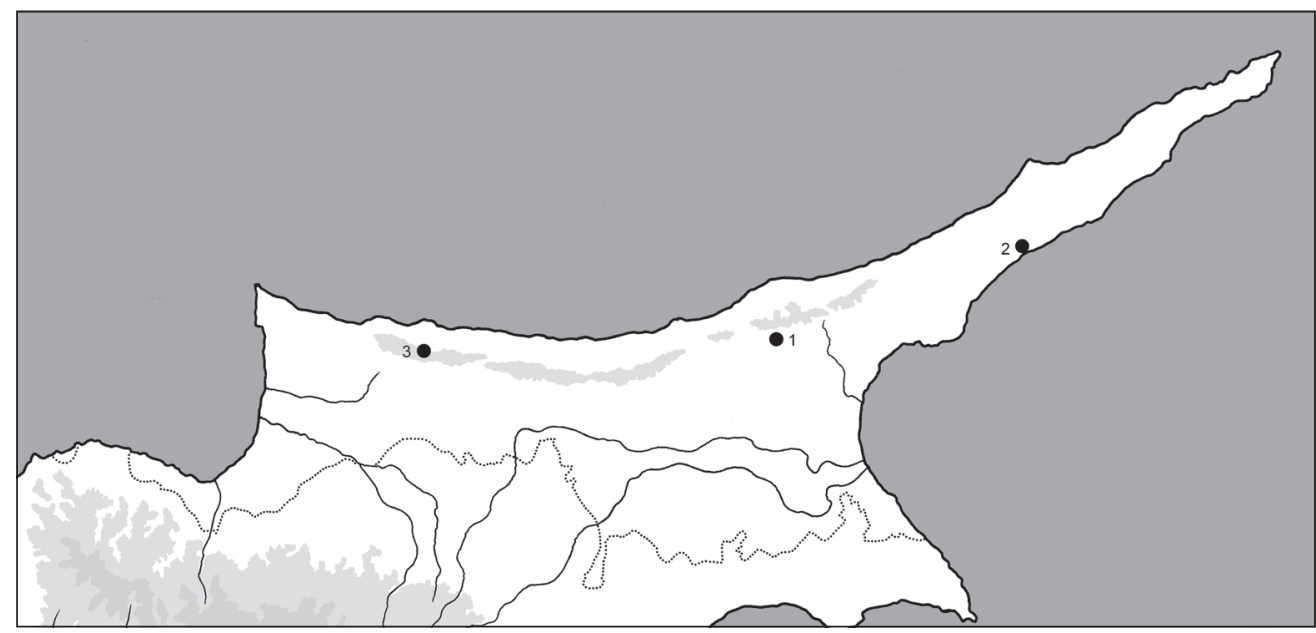

Fig. 14. Records of Geoffroy's bat (Myotis emarginatus) in Northern Cyprus; for the map legend see Fig. 1. Obr. 14. Nálezy netopýra brvitého (Myotis emarginatus) na Severním Kypru; vysvětlivky mapy viz obr. 1.

(namely for maternity colonies) in Cyprus conforms to the observations of this bat from southern Turkey and the western Levant (BENDA \& HorÁČEK 1997, BENDA et al. 2006, 2010, 2016) and indicates its strict habit to use underground spaces for reproduction colonies as well as for transient aggregations in the Middle East.

\section{Myotis emarginatus (Geoffroy, 1806)}

ReCORDS. Original data: Çınarlı, İnçirli mağara [1], at the cave entrance, 7 May 2018: det. \& rec. calls of 1-2 foraging inds.; - Kumyal1, at an underground quarry ("Kumyalı mağarası") [2], 10 May 2018: det. $\&$ rec. calls of several foraging inds.; - Malatya, at a mountain spring above the village [3], 18 May 2018: net. 1 ad, 6 October 2018: det. \& rec. calls of 3 foraging inds.

Geoffroy's bat (Myotis emarginatus) is a rare bat in Northern Cyprus (reported here for the first time from the country), similarly as was shown for the southern part of Cyprus by BENDA et al. (2007). Three records were made at various altitudes (Fig. 14), from near the sea level (Kumyalı quarry; Fig. 4) up to the upper part of the Beşparmak (Kyrenia) range above Malatya, at ca. $570 \mathrm{~m}$ a. s. 1. (Fig. 15). A foraging bat was netted only at the latter site, while the two remaining records represent recordings of echolocation calls. The wide range of these three records (690 m, see Table 2, Fig. 3) conforms with the previous findings from Southern Cyprus, where two records were made in a range of more than 1,500 m (BENDA et al. 2007), as well as the distribution patterns in Turkey and the Levant (KARATAŞ \& ÖzGÜL 2003, Benda et al. 2016).

\section{Myotis capaccinii (Bonaparte, 1837)}

ReCord. Published data: Kyrenia [= Girne], 19 May 1960: 1 ind. (Kock 1974, cf. Kahmann \& ÇaĞLaR 1959, 1960). 
According to the available data, only one individual of the long-fingered bat (Myotis capaccinii) was reported to be found in Cyprus (Kock 1974), and this report (even in a preliminary version by KAHMANN \& ÇAĞLAR 1959, 1960) was accepted by subsequent authors (HARRISON 1964, Spitzenberger 1979, Boye et al. 1990, Harrison \& Bates 1991, KryštufeK \& Vohralík 2001, HADJISTERKotis 2006). The occurrence of $M$. capaccinii in Cyprus can be considered probable since this bat species is rather common in the mainland regions neighbouring Cyprus, in southern Turkey and the Levant (KARATAŞ et al. 2003, BENDA et al. 2006, 2016) as well as in Crete (BENDA et al. 2009). However, BENDA et al. (2007) reasonably doubted the credibility of this report and considered it to be inaccurate. Our results support this opinion due to the complete lack of calls of this bat in the huge series of recorded call sequences - some of these recordings were made at water bodies, sometimes for several hours, where this bat would be expected to forage, if it occurs in the area.

\section{Eptesicus serotinus (Schreber, 1774)}

Records. Original data: Ağırdağ, Sicak mağara [1], at the cave entrance, 9 July 2015: det. calls; Gazimağusa, Çanakkale Göleti [2], at the lake, 6 May 2018: det. \& rec. calls of numerous foraging inds., 8 May 2018: det. \& rec. calls of numerous foraging inds.; - Gazimağusa, Venetian citadel [3], former prison, 25 July 2006: obs. 5 inds. roosting in vault fissures (exam. 1 + ad) (cf. BendA et al. 2007); - Göçeri [4], village, 9 October 2018: det. \& rec. calls of 1 foraging ind.; - Kalkanl1, olive grove reserve [5], at a water reservoir, 16 May 2018: det. \& rec. calls of 1-2 foraging inds.

BENDA et al. (2007) reported a single record of the common serotine bat (Eptesicus serotinus) from Northern Cyprus, when several bats were found scattered throughout fissures between stones of the Venetian citadel in Gazimagusa (Famagusta) in the second half of July, as a presumably dispersed remnant of a maternity colony (the respective part of the citadel is currently closed for public visits and there is no opportunity to check possible further use of this roost).
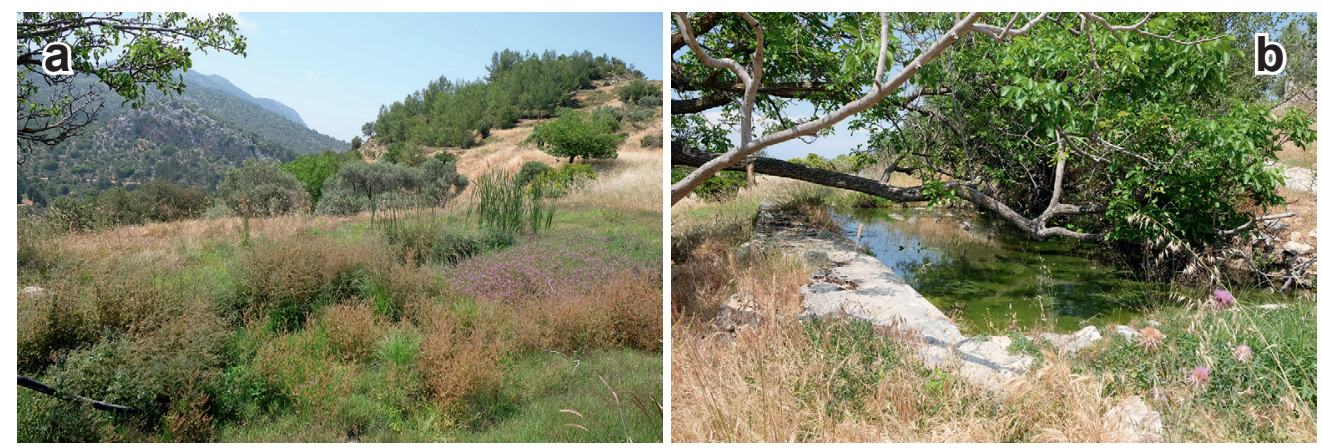

Fig. 15. Two views of the neglected garden above the village of Malatya on the northern slope of the Beşparmak (Kyrenia) range at ca. $570 \mathrm{~m}$ a. s. 1., a site of occurrence of seven bat species; a - general view of the site, $\mathrm{b}-\mathrm{a}$ reservoir at which netting and detectoring were made.

Obr. 15. Dva pohledy na zanedbanou zahradu nad vsí Malatya na severním svahu hřebene Beşparmak ve výšce cca $570 \mathrm{~m} \mathrm{n}$. m., lokalitu výskytu sedmi druhů netopýrů; a - celkový pohled na lokalitu, b - nádrž, nad kterou probíhal odchyt netopýrů do sítě a detekce jejich hlasů. 


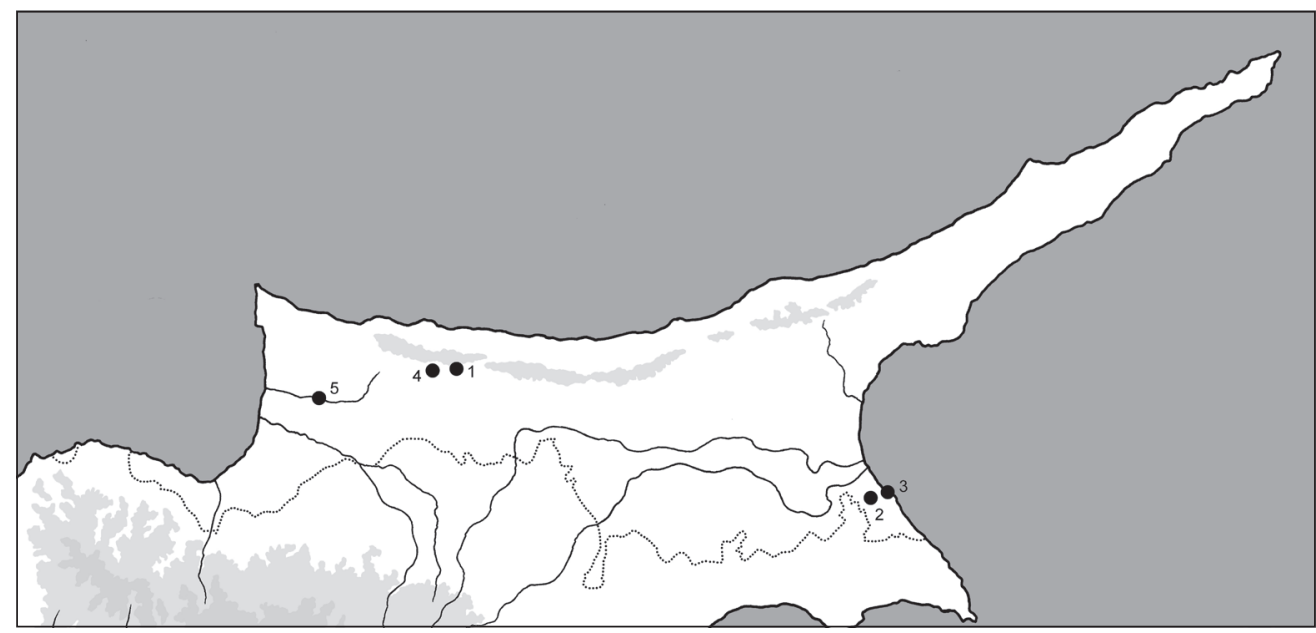

Fig. 16. Records of the common serotine bat (Eptesicus serotinus) in Northern Cyprus; for the map legend see Fig. 1.

Obr. 16. Nálezy netopýra večerního (Eptesicus serotinus) na Severním Kypru; vysvětlivky mapy viz obr. 1.

This record represents the only roost finding of this bat in Northern Cyprus, with new records solely comprising the detections of echolocation calls of bats at their foraging grounds. Thus, E. serotinus is a rather rare bat in the country, with only five records available (Fig. 16). These limited findings are scattered across a rather wide altitude range (Table 2, Fig. 3) from various environments. This pattern is in agreement with that by BENDA et al. (2007) and indicates $E$. serotinus as a universal bat of Cyprus concerning its altitude and habitat preferences, similarly as in southern Turkey and the western Levant (SPITZENBERGER 1994, BENDA \& HorÁČEK 1998, BENDA et al. 2006, 2016).

\section{Eptesicus anatolicus Felten, 1971}

RECORD. Original data: Kantara, Kantara kalesi, courtyard, 25 July 2006: net. 1 đ ad (cf. Benda et al. 2007, ŠEVČík et al. 2013).

The Anatolian serotine bat (Eptesicus anatolicus) was recorded only once in Cyprus when an adult male was netted in the ruins of Kantara castle on the eastern edge of the Beşparmak (Kyrenia) range at $582 \mathrm{~m}$ a. s. 1. in summer 2006 (BENDA et al. 2007). There were no additional records during the recent survey. The uniqueness of the Kantara record is surprising in the light of the rather common occurrence of this bat along the southern Anatolian and Levantine coasts (Spitzenberger 1994, Benda et al. 2006, 2016), and some Aegean Islands (von Helversen 1998, BENDA \& Uhrin 2017). The absence of the call of E. anatolicus among the numerous sequences recorded along the Northern Cypriot coast suggests an irregular or even accidental occurrence of this bat in Cyprus in summer 2006. 


\section{Hypsugo savii (Bonaparte, 1837)}

ReCords. Original data: Alevkaya, Alevkaya kanyon [1], at the cave entrance, 8 July 2015: det. calls; - Esentepe, Dik Burnu [2], sea front resort, 30 September 2018: det. \& rec. calls of 1-2 foraging inds.; Gazimağusa, Çanakkale Göleti [3], at the lake, 8 May 2018: det. \& rec. calls of numerous foraging inds.; - Kalkanl1, olive grove reserve [4], at a water reservoir, 7 October 2018: det. \& rec. calls of 1 foraging ind.; - Kantara, Kantara kalesi [5], fissure in a vaulted ceiling, 18 April 2005: obs. \& exam. 1 od (cf. BENDA et al. 2007), 5 May 2009: obs. \& exam. 1 ठૈ ad; - Sadrazamköy [6], beach resort, 5 October 2018: det. \& rec. calls of 1 foraging ind.

Savi's pipistrelle (Hypsugo savii) is an uncommon bat in Northern Cyprus with only six records (Fig. 17). Only two findings are associated with higher altitudes of the Beşparmak (Kyrenia) range (582 $\mathrm{m}$ and $662 \mathrm{~m}$ a. s. 1., respectively), including the only roost site, documented at Kantara castle, where this bat was found repeatedly. The remaining four records were made at lowland sites at altitudes below $100 \mathrm{~m}$ a. s. 1. The scarcity of records and their strictly bimodal altitudinal distribution is in sharp contrast with findings from the southern part of the island (BENDA et al. 2007) as well as from mainland areas in the eastern Mediterranean (BENDA \& HoRÁČEK 1998, BENDA et al. 2006, 2016) and from Crete (BENDA et al. 2009). In all these areas, $H$. savii prefers high situated sites, while only a minority of records come from low situated areas.

\section{Pipistrellus pipistrellus (Schreber, 1774)}

RECORDS. Original data: Afendrika, at ruins of the Asomatos church [1], 6 May 2018: det. \& rec. calls of 3-4 foraging inds.; - A ğırdağ, at the airport [2], 14 May 2018: det. \& rec. calls of 1 foraging ind., 9 October 2018: det. \& rec. calls of 1 foraging ind.; - Ağırdağ, Sicak mağara [3], at the entrance, 20 August 2016: det. calls of several foraging inds.; - Ağırdağ, southern margin of the village [4], 14 May 2018: det. \& rec. calls

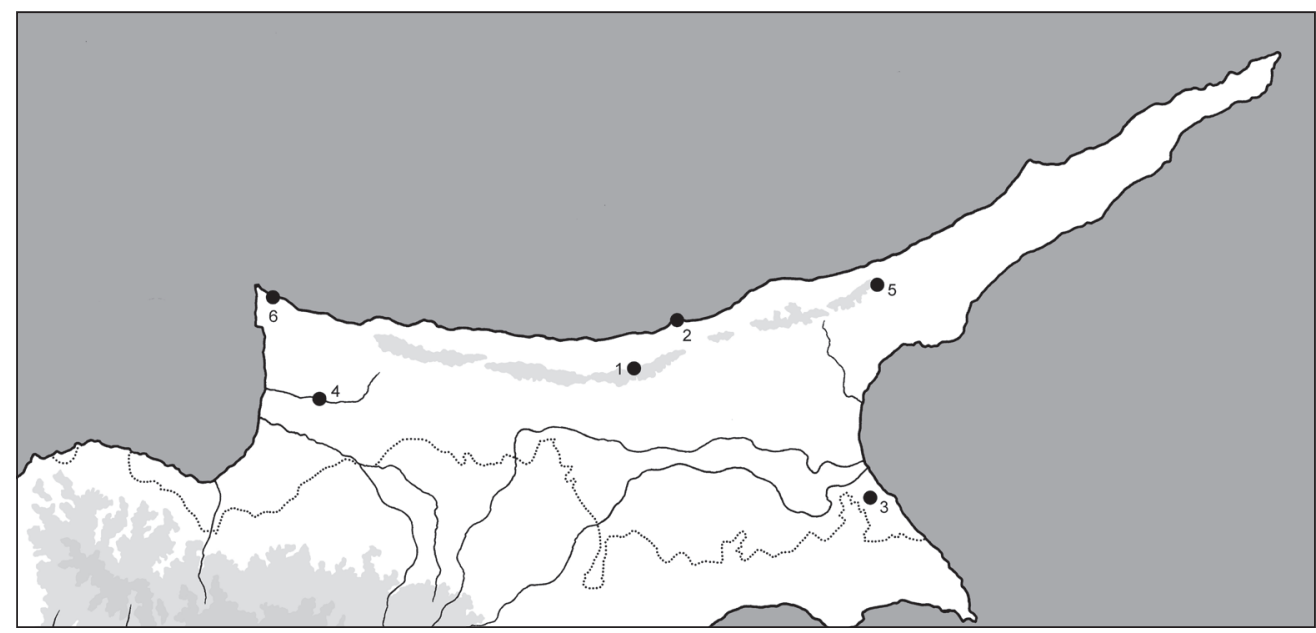

Fig. 17. Records of Savi's pipistrelle (Hypsugo savii) in Northern Cyprus; for the map legend see Fig. 1. Obr. 17. Nálezy netopýra Saviova (Hypsugo savii) na Severním Kypru; vysvětlivky mapy viz obr. 1. 
of 1 foraging ind.; - Akçiçek, village [5], 12 May 2018: det. \& rec. calls of 1 foraging ind.; - Akdoğan, eastern margin of the village [6], 3 October 2018: det. \& rec. calls of 1 foraging ind.; - Akıncilar, northern margin of the village [7], 3 October 2018: det. \& rec. calls of 1 foraging ind.; -Alayköy, western margin of the village, [8], 9 October 2018: det. \& rec. calls of 1 foraging ind.; - Alevkaya, Küpo mağaras1 [9], at the cave entrance, 3 August 2015: det. calls, 2 October 2018: det. \& rec. calls of 1 foraging ind.; - Alevkaya, Saray mağaras1 [10], at the cave entrance, 12 July 2015: det. calls; - Alevkaya, crossing of roads above the Sourp Magar monastery ruins [11], 2 October 2018: det. \& rec. calls of 1 foraging ind.; - Ayfilon [12], at the basilica ruins, 1 October 2018: det. \& rec. calls of 1 foraging ind.; - Camlibel, an orchard $2.5 \mathrm{~km}$ north-west of the village [13], 13 May 2018: det. \& rec. calls of 1 foraging ind.;-C Camlıbel, village [14], 14 May 2018: det. \& rec. calls of 1 foraging ind.; - Çamlıköy, village [15], 15 May 2018: det. \& rec. calls of 1-2 foraging inds.; - Çatalköy, village [16], 30 September 2018: det. \& rec. calls of 1-2 foraging inds.; - Çayönü, western margin of the village [17], 6 May 2018: det. \& rec. calls of 1 foraging ind.; - Dilekkaya, village [18], 3 October 2018: det. \& rec. calls of 2-3 foraging inds.; - Dipkarpaz, village [19], 6 May 2018: det. \& rec. calls of 1 foraging ind., 1 October 2018: det. \& rec. calls of 1 foraging ind., 4 October 2018: det. \& rec. calls of 1 foraging ind.; - Doğanköy, village [20], 8 October 2018: det. \& rec. calls of 1-2 foraging inds.; - Ergenekon, Dumanlı mağara [21], 1 May 2018: coll. osteological remains of 2 inds. of Pipistrellus cf. pipistrellus (leg. \& det. C. DodeLIN); - Esentepe, forested slope above the village [22], 9 May 2018: det. \& rec. calls of 1 foraging ind.; - Gazimağusa, Çanakkale Göleti [23], at the lake, 8 May 2018: det. \& rec. calls of numerous foraging inds.; - Gazimağusa, old town [24], 5 May 2018: det. \& rec. calls of 1-2 foraging inds., 4 October 2018: det. \& rec. calls of several foraging inds.; - Güzelyurt, south-western margin of the town [25], 7 October 2018: det. \& rec. calls of 1 foraging ind.; - İnönü, western margin of the village [26], 3 October 2018: det. \& rec. calls of 1 foraging ind.; - Kalkanl1, olive grove reserve [27], at a water reservoir, 16 May 2018: det. \& rec. calls of numerous foraging inds., 7 October 2018: det. \& rec. calls of numerous foraging inds.; - Karşıyaka, road crossing in the ridge above the village [28], 6 October 2018: det. \& rec. calls of 2 foraging inds.; - Karş1yaka, western margin of the town [29], 5 October 2018: det. \& rec. calls of 1 foraging ind.; - Kayalar, coastal habitats in a resort ca. 2 km east of the village [30], 13 May 2018: det. \& rec. calls of 1 foraging ind.; - Kaynakköy [31], village, 3 October 2018: det. \& rec. calls of 1 foraging ind.; - Kozan, village [32], 6 October 2018: det. \& rec. calls of 1 foraging ind., 9 October 2018: det. \& rec. calls of 1-2 foraging inds.; - Küçük Erenköy, sea shore [33], 30 September 2018: det. \& rec. calls of 2 foraging inds.; - Lapta, above a water reservoir at an entrance to a water line gallery [34], 12 May 2018: det. \& rec. calls of numerous foraging inds., 9 October 2018: det. \& rec calls of 1 foraging ind.; - Lapta, western margin of the town [35], 9 October 2018: det. \& rec calls of 1 foraging ind.; - Lefke, above a stream at the bridge at Acendu [36], 15 May 2018: det. \& rec. calls of numerous foraging inds.; - Lefkoşa, old town and surrounding streets [37], 14 May 2018: det. $\&$ rec calls of 1 foraging ind.; - Malatya, at a mountain spring above the village [38], 6 October 2018: det. \& rec. calls of 3-5 foraging inds; - Pınarbaşı, eastern margin of the village [39], 14 May 2018: det. $\&$ rec. calls of 1 foraging ind.; - Sadrazamköy, at a water reservoir next to a beach resort [40], 13 May 2018: det. \& rec. calls of numerous foraging inds., 5 October 2018: det. \& rec. calls of numerous foraging inds.; - Şirinevler, northern margin of the village [41], 14 May 2018: det. \& rec. calls of 2 foraging inds., 9 October 2018: det. \& rec. calls of 1 foraging ind.; - Sütlüce, northern margin of the village [42], 10 October 2018: det. \& rec. calls of 1 foraging ind.; - Tatlisu, village [43], 4 October 2018: det. \& rec. calls of 3 foraging inds.; - Türkeli, eastern margin of the village [44], 9 October 2018: det. \& rec. calls of 1 foraging ind.; - Yayla, village [45], 7 October 2018: det. \& rec. calls of 2 foraging inds.; - Yayla Tepe, forested southern slope of the peak [46], 2 October 2018: det. \& rec. calls of numerous foraging inds.; Yeşilköy, village [47], 4 October 2018: det. \& rec. calls of 2 foraging inds.; - Yeşilköy, road and fields $2 \mathrm{~km}$ north of the village [48], 4 October 2018: det. \& rec. calls of 1 foraging ind.; - Yeşilyurt, western margin of the village [49], 15 May 2018: det. \& rec. calls of 1 foraging ind.; - Yiğitler [50], village, 3 October 2018: det. \& rec. calls of 2 foraging inds.

According to BENDA et al. (2007), the common pipistrelle (Pipistrellus pipistrellus) was extremely rare in Cyprus, documented from only two sites in the forested mountainous areas of the southern 


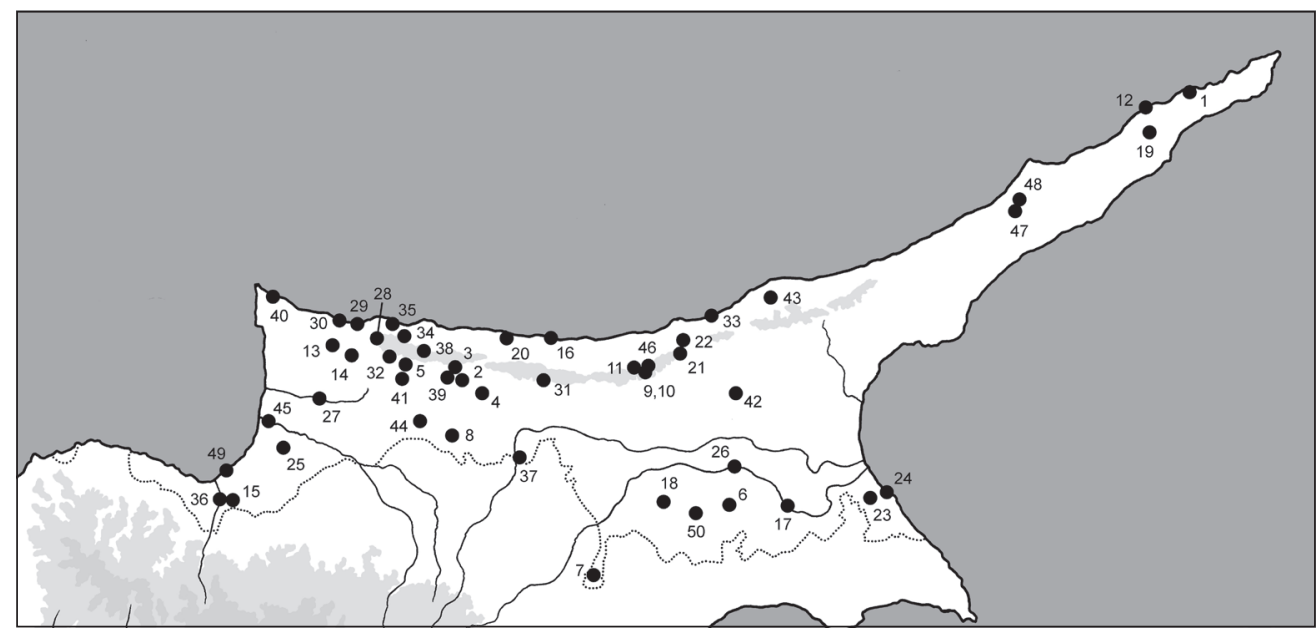

Fig. 18. Records of the common pipistrelle (Pipistrellus pipistrellus) in Northern Cyprus; for the map legend see Fig. 1.

Obr. 18. Nálezy netopýra hvízdavého (Pipistrellus pipistrellus) na Severním Kypru; vysvětlivky mapy viz obr. 1.

part of the island, at 1,595 and 1,665 $\mathrm{m}$ a. s. 1., respectively. In sharp contrast, the results of our recent survey have found this bat to be extremely widespread and the second most frequently recorded species among Northern Cypriot bats (Table 1). Although P. pipistrellus is reported here for the first time from Northern Cyprus, it was documented in 50 localities (Fig. 18), spread over a wide range of $880 \mathrm{~m}$, with a dominance of lowland and medium elevated sites (altitude median $128.0 \mathrm{~m}$ a. s. 1.; Table 2). Only echolocation calls of foraging individuals were detected and recorded in Northern Cyprus, plus one osteological finding in a cave; however, the calls were documented in all habitats of the country, in settlements, near wetlands and larger water bodies, in open agriculural landscapes and in forests. Hence, the previous premise by BENDA et al. (2007) of the exclusive mountainous occurrence of $P$. pipistrellus in Cyprus is incorrect. Although in the lowlands of Northern Cyprus, this bat is less common than the widespread Pipistrellus kuhlii (see below), both species occur in more or less similar densities at medium and high altitudes. At the highest locality of this species' occurrence, Yayla Tepe (885 m a. s. 1.), $P$. pipistrellus was foraging together with $P$. kuhlii, though at a much higher abundance than the latter species. The situation in Cyprus is unlike Crete, where the only member of the $P$. pipistrellus complex, the Cretan pipistrelle, $P$. (hanaki) creticus, prefers to occur in forests, which are distributed mainly in the mountains, and thus, it is rather rare on the island (BENDA et al. 2009, Georgiakakis et al. 2018). On the other hand, in the Levantine part of the Mediterranean, P. pipistrellus occurs in similar densities to Northern Cyprus (see BENDA et al. 2006, 2010, 2016) and in the whole easternmost part of the Mediterranean arboreal zone this bat represents a common component of the bat fauna. 


\section{Pipistrellus pygmaeus (Leach, 1825)}

RECORDS. Original data: Afendrika, at ruins of the Asomatos church [1], 6 May 2018: det. \& rec. calls of 1-2 foraging inds.; - Esentepe, forested slope above the Antifontis church [2], 9 May 2018: det. \& rec. calls of 1 foraging ind.; - Kalkanl, olive grove reserve [3], at a water reservoir, 16 May 2018: det \& rec. calls of 1 foraging ind., 7 October 2018: det. \& rec. calls of several foraging inds.; - Köprülü, Köprülü Göleti [4], at the lake bank ca. $1 \mathrm{~km}$ north of the village, 6 May 2018: det. \& rec. calls of several foraging inds.; - Kozan, village [5], 12 May 2018: det. \& rec. calls of 1 foraging ind.; - Lapta, above a water reservoir at an entrance to a water line gallery [6], 12 May 2018: det. \& rec. calls of 1 foraging ind.; - Lefke, above a stream at the bridge at Acendu [7], 15 May 2018: det. \& rec. calls of several foraging inds.; - Malatya, at a mountain spring above the village [8], 6 October 2018: det. \& rec. calls of numerous foraging inds; Sadrazamköy [9], at a water reservoir next to a beach resort, 5 October 2018: det. \& rec. calls of several foraging inds.; - Yeşilırmak, village [10], 15 May 2018: det. \& rec. calls of 1-2 foraging inds.

The soprano pipistrelle (Pipistrellus pygmaeus) is reported here for the first time from Northern Cyprus, where it does not seem to be rare. Its echolocation calls were recorded at ten localities (Fig. 19), while no netted individuals or bats in roosts were found. The broad scale detectoring demostrated that this species is less abundant than P. pipistrellus in the northern part of Cyprus (contrary to the supposition by BENDA et al. 2007). The available records of these species are at a ratio of 1:5 with the dominance of the latter species (see above). Although most records of $P$. pygmaeus in Northern Cyprus were made in low situated areas and the bat seems to represent an element of lowland environments (Fig. 3), all low situated records represent few or single foraging bats recorded per site. The only large aggregation of foraging bats of this species was documented at a mountain spring above Malatya (Fig. 15), in the north-western part of the Beşparmak (Kyrenia) range, at ca. $570 \mathrm{~m}$ a. s. 1., the highest situated site of this bat in the

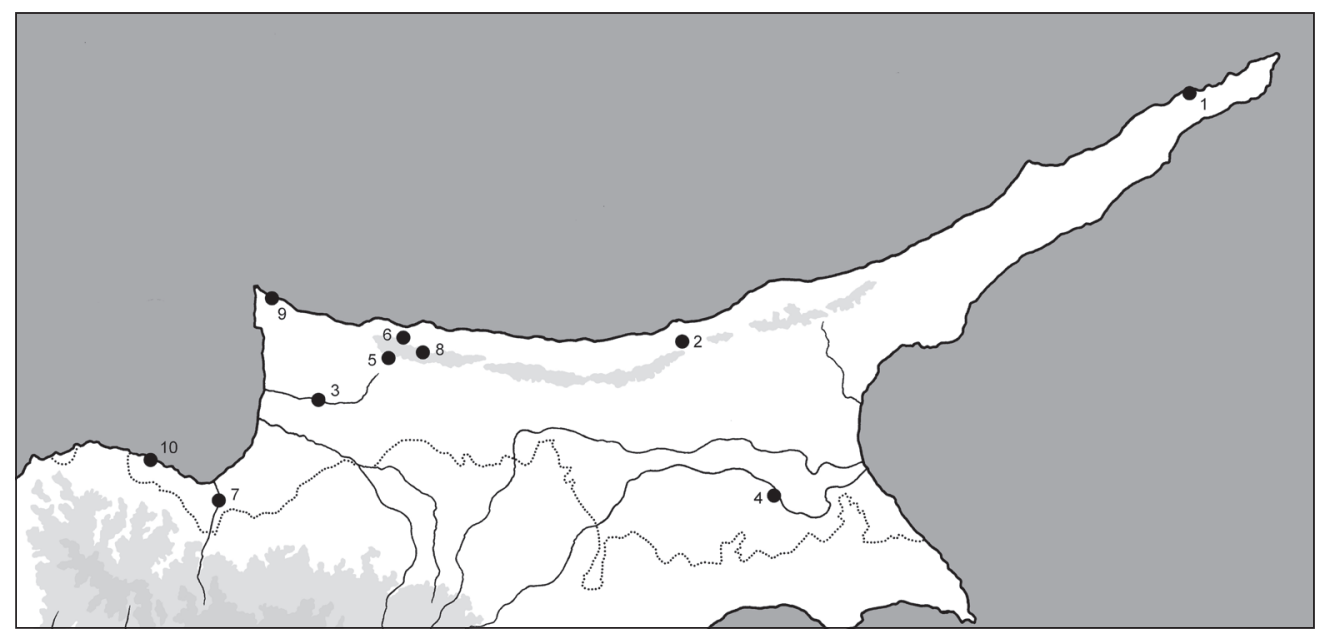

Fig. 19. Records of the soprano pipistrelle (Pipistrellus pygmaeus) in Northern Cyprus; for the map legend see Fig. 1.

Obr. 19. Nálezy netopýra nejmenšího (Pipistrellus pygmaeus) na Severním Kypru; vysvětlivky mapy viz obr. 1. 
country. This disproportion may suggest a certain affinity of $P$. pygmaeus to forested mountains in Cyprus as was presumed by BENDA et al. (2007) on the basis of the findings from Southern Cyprus (recorded in the altitudinal range of 425-1,770 m a. s. 1.; mean 1,263 m). The available records clearly show this species to be a medium frequent bat in Northern Cyprus, occurring at most altitudinal levels of the country.

\section{Pipistrellus kuhlii (Kuhl, 1817)}

RECORDS. Original data: Afendrika, ruins of the Asomatos church, 17 October 2005: net. 7 ते $\hat{\text { ad, }} 1$ के sad,

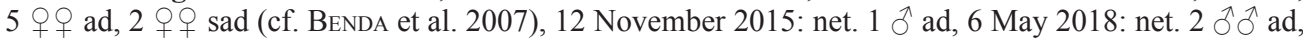
det. \& rec. calls of numerous foraging inds.; - Afendrika, ruins of the Panagia Chrysiotissa church, fissures of a vaulted ceiling, 25 July 2006: obs. a dispersed colony of min. 8 inds., exam. 1 त ad, 1 ㅇ ad (cf. Benda et al. 2007), 4 May 2009: obs. 11 roosting inds., 3 March 2010: obs. 7 inds., 12 November 2015: obs. 16 roosting inds., 13 November 2015: obs. 21 roosting inds., 29 March 2017: obs. 4 roosting inds., 20 January 2018: obs. 4 roosting inds., 6 May 2018: obs. 8 roosting inds., 1 October 2018: obs. 18 roosting inds.; - Afendrika, coastal habitats and road $1 \mathrm{~km}$ west of the Panagia Chrysiotissa church, 1 October 2018: det. \& rec. calls of 4 foraging inds.; - Afendrika, coastal habitats and road $2 \mathrm{~km}$ west of the Panagia Chrysiotissa church, 6 May 2018: det. \& rec. calls of 1 foraging ind., 1 October 2018: det. \& rec. calls of numerous foraging inds.; - Ağ1llar, at a spring ca. $1 \mathrm{~km}$ east of the village, 11 May 2018: det. \& rec. calls of several foraging inds.; - A ğ1llar, village, 11 May 2018: det. \& rec. calls of 2 foraging inds; - A $\breve{g} ı$ rda $\breve{g}$, at the airport, 14 May 2018: det. \& rec. calls of 1-2 foraging inds., 9 October 2018: det. \& rec. calls of 3-4 foraging inds.; - Ağırdağ, Sicak mağara, at the cave entrance, 20 August 2016: det. calls of several foraging inds.; - Ağırdağ, southern margin of the village, 9 October 2018: det. \& rec. calls of 3 foraging inds.; - Akçay, village, 7 October 2018: det. \& rec. calls of 4 foraging inds.; - Akçiçek, slope above the village, 12 May 2018: det. \& rec. calls of 1 foraging ind., 9 October 2018: det. \& rec. calls of 4 foraging inds.; - Akdoğan, eastern part of the village, 3 October 2018: det. \& rec. calls of 4 foraging inds.; Akincilar, northern part of the village, 10 October 2018: det. \& rec. calls of numerous foraging inds.; Akincilar, at the road $2 \mathrm{~km}$ north of the village, 10 October 2018: det. rec. calls of 2 foraging inds.; Akova, northern margin of the village, 6 May 2018: det. \& rec. calls of 1 foraging ind.; - Akova, road and fields $1 \mathrm{~km}$ west of the village, 6 May 2018: det. \& rec. calls of 2 foraging inds.; - Alaniçi, southern margin of the village, 6 May 2018: det. \& rec. calls of 1 foraging ind.; - Alayköy, western margin of the village, 9 October 2018: det. \& rec. calls of 1 foraging ind.; - Alemdağ, village, 12 May 2018: det. \& rec. calls of 2 foraging inds., 9 October 2018: det. \& rec. calls of 1 foraging ind.; - Alevkaya, Alevkaya kanyon, at the cave entrance, 8 July 2015: det. calls, 22 August 2016: det. calls of numerous inds.; - Alevkaya, on forest road at the Girne Kayasi view area, 2 October 2018: det. \& rec. calls of 1 foraging ind.; - Alevkaya, Küpo mağaras1, at the cave entrance, 9 May 2018: det. \& rec. calls of 1 foraging ind., 2 October 2018: det. \& rec. calls of several foraging inds.; - Alevkaya, Saray mağaras1, at the cave entrance, 12 July 2015: det. calls, 24 August 2016: det. calls of 1-2 foraging inds.; - Altınova, Sinirli yarasa mağaras1, at the cave entrance, 5 August 2015: det. calls, 25 August 2016: det. calls of numerous inds.; - Alevkaya, crossing of roads above the Sourp Magar monastery ruins, 8 October 2018: det. \& rec. calls of 2 foraging inds.; - Alsancak, village, 5 October 2018: det. \& rec. calls of 1-2 foraging inds.; - Altınova, village, 11 May 2018: det. \& rec. calls of 1 foraging ind.; - Altınova, at the road ca. $1 \mathrm{~km}$ south of the village, 11 May 2018: det. \& rec. calls of 1 foraging ind.; - Antifonitis Kilisesi, forested slope above the church, 9 May 2018: det. \& rec. calls of 2 foraging inds.; - Apostolos Andreas manastır1, square, 1 October 2018: det. $\&$ rec. calls of 2-3 foraging inds.; - Arapköy, village, 8 October 2018: det. \& rec. calls of 2-3 foraging inds.; - Arapköy, at the road ca. $1.5 \mathrm{~km}$ north of the village, 8 October 2018: det. \& rec. calls of several foraging inds.; - Ardahan, southern margin of the village, 11 May 2018: det. \& rec. calls of 1 foraging ind.; - Aşağ1 Bostanc1, village, 7 October 2018: det. \& rec. calls of 4 foraging inds.; - Aşağ village, 2 October 2018: det. \& rec. calls of 2-3 foraging inds.; - Aslanköy, at the crossing of roads $3 \mathrm{~km}$ east of the village, 10 October 2018: det. \& rec. calls of 3-5 foraging inds.; - Aslanköy, at the field and 
road ca. $2 \mathrm{~km}$ south of the village, 10 October 2018: det. \& rec. calls of 3-4 foraging inds.; - Avtepe, village, 6 May 2018: det. rec. calls of 2 foraging inds.; - Aydınköy, eastern part of the village, 7 October 2018: det. \& rec. calls of 4-5 foraging inds.; - Ayfilon, basilica ruins, fissures in a vault ceiling, 25 July 2006: obs. a group of 4 roosting inds. (cf. BENDA et al. 2007), 4 May 2009: obs. 7 roosting inds., at the basilica ruins, 1 October 2018: det. \& rec. calls of numerous foraging inds.; - Ayfilon, coastal habitats ca. $0.5 \mathrm{~km}$ east of the basilica ruins, 1 October 2018: det. \& rec. calls of 2 foraging inds.; - Ayfilon, road and fields ca. $1 \mathrm{~km}$ south-south-east of the basilica ruins, 6 May 2018: det. \& rec. calls of 2 foraging inds., 1 October 2018: det. \& rec. calls of several foraging inds.; - Ayfilon, coastal habitats ca. $1 \mathrm{~km}$ south-west of the basilica ruins, 1 October 2018: det. \& rec. calls of 1 foraging ind.; - Ayfilon, coastal habitats at Roman harbor, ca. $1.5 \mathrm{~km}$ east of the basilica ruins, 1 October 2018: det. \& rec. calls of 3 foraging inds.; - Ayfilon, coastal habitats east of the Roman harbor, ca. $2.5 \mathrm{~km}$ east of the basilica ruins, 6 May 2018: det. \& rec. calls of 8 foraging inds., 1 October 2018: det. \& rec. calls of 1 foraging ind.; - Bademliköy, village, 15 May 2018: det. \& rec. calls of several foraging inds.; - Bafra, village, 10 May 2018: det. \& rec. calls of 3 foraging inds.; - Bahçeli, above a stream bed $2 \mathrm{~km}$ north-east of the village, 21 January 2018: det. \& rec. calls of at least 1 foraging ind.; - Bahçeli, forested slope above the village, 9 May 2018: det. $\&$ rec. calls of 1 foraging ind.; - Bahçeli, coastal habitats north of the village, 30 September 2018: det. $\&$ rec. calls of 3-4 foraging inds.; - Bahçeli, at the main road north of the village, 9 May 2018: det. \& rec. calls of 3 foraging inds., 30 September 2018: det. \& rec. calls of 2-3 foraging inds.; - Bahçeli, at the coastal road north-east of the village, 30 September 2018: det. \& rec. calls of 12 foraging inds.; - Bahçeli, at the main road north-west of the village, 30 September 2018: det. \& rec. calls of 3 foraging inds.; Balalan, village, 10 May 2018: det. \& rec. calls of 2 foraging inds., 4 October 2018: det. \& rec. calls of 2 foraging inds; - Beşparmak pass, 2 October 2018: det. \& rec. calls of 3 foraging inds., 8 October 2018: det. \& rec. calls of 1 foraging ind.; - Beylerbeyi, Bellapais Abbey ruins, fissures in vaulted ceilings, 27 July 2006: obs. 8 roosting inds. (cf. BendA et al. 2007), 22 January 2018: obs. 3 roosting inds. torpid, 13 May 2018: obs. 1 roosting ind.; - Beylerbeyi, village, 8 October 2018: det. \& rec. calls of 6 foraging inds.; Boğaziçi, village, 6 May 2018: det. \& rec. calls of 1 foraging ind.; - Boğazköy, village, 2 October 2018: det. \& rec. calls of 4 foraging inds.; - Boğaztepe, village, 11 May 2018: det. \& rec. calls of 2-3 foraging inds.; - Boltaşl1, village, 6 May 2018: det. \& rec. calls of 1 foraging ind.; - Büyükkonuk, village, 10 May 2018: det. \& rec. calls of 3 foraging inds.; - Büyükkonuk, coastal habitats ca. $5 \mathrm{~km}$ north-west of the village, 4 October 2018: det. \& rec. calls of 1-2 foraging inds.; - Çamlıbel, barracks, 13 May 2018: det. $\&$ rec. calls of 1 foraging ind.; - Çamlıbel, an orchard $2.5 \mathrm{~km}$ north-west of the village, 12 May 2018: det. $\&$ rec. calls of 1 foraging ind., 13 May 2018: det. \& rec. calls of 1 foraging ind., 14 May 2018: det. \& rec. calls of 1 foraging ind.; - Çamlıbel, village, 13 May 2018: det. \& rec. calls of 2 foraging inds., 14 May 2018: det. \& rec. calls of 2 foraging inds.; - Çamlıca, village, 10 October 2018: det. \& rec. calls of 3 foraging inds.; - Çamlica, road and fields ca. $1 \mathrm{~km}$ south of the village, 10 October 2018: det. \& rec. calls of 2 foraging inds.; - Çamlıköy, village, 15 May 2018: det. \& rec. calls of 5 foraging inds.; - Çatalköy, village, 30 September 2018: det. \& rec. calls of 3 foraging inds.; - Çatalköy, at a crossing of main roads, 21 January 2018: det. \& rec. calls of 1 foraging ind.; - Çatalköy, at the main road near Acapulco resort, 30 September 2018: det. \& rec. calls of 1 foraging ind.; - Çatalköy, coastal habitats north of the village, 30 September 2018: det. \& rec. calls of 10 foraging inds.; - Çatalköy, coastal habitats north-east of the village, 30 September 2018: det. \& rec. calls of 5 foraging inds.; - Çatalköy, coastal habitats north-west of the village, 30 September 2018: det. \& rec. calls of 5 foraging inds.; - Çayönü, eastern margin of the village, 6 May 2018: det. \& rec. calls of 3 foraging inds.; - Çayönü, western margin of the village, 6 May 2018: det. \& rec. calls of 2-3 foraging inds.; - Çınarlı, İnçirli mağara, at the cave entrance, 7 May 2018: det. \& rec. calls of 1 foraging ind., 3 October 2018: det. \& rec. calls of 3 foraging inds.; - Çınarlı, at the crossing of the road from the village and main road, ca. $3 \mathrm{~km}$ north-north-west of the village, 9 May 2018: det. \& rec. calls of 2 foraging inds.; - Çınarlı, village, 5 May 2018: det. \& rec. calls of 1 foraging ind.; - Dağyolu, village, 9 October 2018: det. \& rec. calls of 4 foraging inds.; - Dağyolu, fields $1 \mathrm{~km}$ north of the village, 9 October 2018: det. \& rec. calls of 2 foraging inds.; - Değirmenlik, Meraklı pothole, at the cave entrance, 13 July 2015: det. \& rec. calls; - Derince, village, 6 May 2018: det. \& rec. calls of 3 foraging inds.; - Dilekkaya, village, 3 October 2018: det. \& rec. calls of 5-7 foraging inds.; - Dipkarpaz, 
village, 6 May 2018: det. \& rec. calls of 5 foraging inds., 1 October 2018: det. \& rec. calls of 12 foraging inds., 4 October 2018: det. \& rec. calls of 5 foraging inds.; - Dipkarpaz, south-eastern margin of the village, 1 October 2018: det. \& rec. calls of 3 foraging inds.; - Dipkarpaz, coastal habitats ca. $1 \mathrm{~km}$ north-west of the village, 4 October 2018: det. \& rec. calls of 4 foraging inds.; - Dipkarpaz, road and fields $2 \mathrm{~km}$ south of the village, 6 May 2018: det. \& rec. calls of 3 foraging inds.; - Dipkarpaz, coastal habitats ca. $3 \mathrm{~km}$ south-east of the village, 1 October 2018: det. \& rec. calls of 3 foraging inds.; - Dipkarpaz, coastal habitats ca. $6 \mathrm{~km}$ east of the village, 1 October 2018: det. \& rec. calls of 3 foraging inds.; - Dipkarpaz, coastal habitats ca. $6 \mathrm{~km}$ west of the village, 4 October 2018: det. \& rec. calls of 4 foraging inds.; Dipkarpaz, road and fields ca. $8 \mathrm{~km}$ east of the village, 1 October 2018: det. \& rec. calls of 2 foraging inds.; - Dipkarpaz, fields and coastal habitats ca. $10 \mathrm{~km}$ east of the village, 1 October 2018: det. \& rec. calls of 7 foraging inds.; - Dipkarpaz, road and fields ca. $15 \mathrm{~km}$ east of the village, 1 October 2018: det. \& rec. calls of 4 foraging inds.; - Doğanc1, village, 7 October 2018: det. \& rec. calls of 3 foraging inds.; - Doğanköy, village, 8 October 2018: det. \& rec. calls of 4 foraging inds.; - Dörtyol, village, 6 May 2018: det. \& rec. calls of 1 foraging ind., 3 October 2018: det. \& rec. calls of 2-3 foraging inds.; - Ercan Havaliman1, road ca. 2 km east, 10 October 2018: det. \& rec. calls of 4 foraging inds.; - Ercan Havaliman1, road and fields ca. $5 \mathrm{~km}$ east, 10 October 2018: det. \& rec. calls of 7 foraging inds.; - Erdemli, village, 3 October 2018: det. \& rec. calls of 5 foraging inds.; - Erdemli, eastern margin of the village, 3 October 2018: det. \& rec. calls of 1 foraging ind.; - Ergazi, village, 11 May 2018: det. \& calls of 2 foraging inds.; - Ergenekon, village, 7 May 2018: det. \& calls of 1 foraging ind.; - Esentepe, road and coastal habitats north-west of the village, 30 September 2018: det. \& rec. calls of 1 foraging ind.; - Esentepe, forested slope above the village, 9 May 2018: det. \& rec. calls of 4 foraging inds.; - Esentepe, Dik Burnu, sea front resort, 30 September 2018: det. \& rec. calls of 2 foraging inds.; - Esentepe, forested slope $3 \mathrm{~km}$ south-east of the village, 9 May 2018: det. \& rec. calls of 1 foraging ind., 10 October 2018: det. \& rec. calls of 1 foraging ind.; - Gaziköy, barracks, 3 October 2018: det. \& rec. calls of 4 foraging inds., 10 October 2018: det. \& rec. calls of 2 foraging inds.; - Gaziköy, village, 3 October 2018: det. \& rec. calls of 2 foraging inds., 10 October 2018: det. \& rec. calls of 2-3 foraging inds.; - Gaziler, village, 10 October 2018: det. \& rec. calls of 5 foraging inds.; - Gazimağusa, Çanakkale Göleti, at the lake, 6 May 2018: det. \& calls of several foraging inds., 8 May 2018: det. \& calls of numerous foraging inds.; - Gazimağusa, old town, 5 May 2018: det. \& rec. calls of numerous foraging inds., 11 May 2018: det. \& rec. calls of 1 foraging ind., 4 October 2018: det. \& rec. calls of 10 foraging inds.; - Gazimağusa, Baykal, western part, 6 May 2018: det. \& calls of 5 foraging inds., 8 May 2018: det. \& calls of 3 foraging inds.; - Gazimağusa, Sakarya, western part, 8 May 2018: det. \& rec. calls of 1 foraging ind.; - Gaziveren, village, 7 October 2018: det. \& rec. calls of 2 foraging inds.; - Geçitkale, eastern margin of the village, 8 October 2018: det. \& rec. calls of 2-3 foraging inds.; - Geçitkale, road and fields $3 \mathrm{~km}$ north of the village, 8 October 2018: det. \& rec. calls of 2 foraging inds.; - Geçitköy, village, 13 May 2018: det. \& rec. calls of 1 foraging ind.; Geçitköy, coastal habitats $2 \mathrm{~km}$ north of the village, 13 May 2018: det. \& rec. calls of 4 foraging inds., 5 October 2018: det. \& rec. calls of 3-4 foraging inds.; - Gelincik, village, 6 May 2018: det. \& rec. calls of 1 foraging ind., 10 May 2018: det. \& rec. calls of 2 foraging inds.; - Gemikonağ 1 , village, 15 May 2018: det. \& rec. calls of 1 foraging ind.; - Girne, downtown, 5 October 2018: det. \& rec. calls of 5 foraging inds.; - Girne, western part of the town, 5 October 2018: det. \& rec. calls of 2 foraging inds.; - Göçeri, village, 14 May 2018: det. \& rec. calls of 1 foraging ind., 9 October 2018: det. \& rec. calls of 6 foraging inds.; - Gönendere, Gönendere Göleti, around the lake, 7 May 2018: det. \& rec. calls of 4-5 foraging inds.; - Gönendere, south-western margin of the village, 10 October 2018: det. \& rec. calls of 2 foraging inds.; - Gönyeli, northern part of the town, 9 October 2018: det. \& rec. calls of 1 foraging ind.; - Gözübüyük, coastal habitats above Alagadi plaj1, 30 September 2018: det. \& rec. calls of 8 foraging inds.; - Gözübüyük, road and coastal habitats north-east of the village, 30 September 2018: det. \& rec. calls of 18 foraging inds.; - Gözübüyük, road and coastal habitats north-west of the village, 30 September 2018: det. \& rec. calls of 3-4 foraging inds.; - Güngör, forest and road on the ridge north of the village, below the Buffavento castle ruins, 2 October 2018: det. \& rec. calls of 1 foraging ind.; - Güngör, forest and road on the ridge north-east of the village, 2 October 2018: det. \& rec. calls of 1 foraging ind.; - Güzelyurt, town centre, 7 October 2018: det. \& rec. calls of 8 foraging inds.; - Güzelyurt, south-western margin of the 
town, 7 October 2018: det. \& rec. calls of 2 foraging inds.; - İnönü, village, 3 October 2018: det. \& rec. calls of 5 foraging inds.; - İnönü, northern part of the village, 3 October 2018: det. \& rec. calls of 2 foraging inds.; - İnönü, road and fields $1 \mathrm{~km}$ west of the village, 3 October 2018: det. \& rec. calls of 2-3 foraging inds.; - İskele, village, 11 May 2018: det. \& rec. calls of 2-3 foraging inds.; - İskele, southern margin of the village, 6 May 2018: det. \& rec. calls of 1-2 foraging inds.; - İskele, western margin of the village, 11 May 2018: det. \& rec. calls of 1 foraging ind.; - İskele, road and fields ca. $2 \mathrm{~km}$ north of the village, 11 May 2018: det. \& rec. calls of 2 foraging inds.; - Kaleburnu, village, 18 April 2005: det. calls of min. 2 foraging inds. (cf. BendA et al. 2007); - Kaleburnu, road and fields south of the village, 6 May 2018: det. \& rec. calls of 1 foraging ind.; - Kaleburnu, road and fields $2 \mathrm{~km}$ east of the village, 6 May 2018: det. \& rec. calls of 1 foraging ind.; - Kaleburnu, road and fields ca. $5 \mathrm{~km}$ east of the village, 6 May 2018: det. \& rec. calls of 2 foraging inds.; - Kalkanl1, olive grove reserve, above a water reservoir, 16 May 2018: net. $2 \hat{\delta} \widehat{\partial}$ ad, $1 \hat{\delta} \mathrm{sad}$, det. \& rec. calls of numerous foraging inds., 7 October 2018: net. 1 \& sad, det. \& rec. calls of numerous foraging inds.; - Kantara, Kantara kalesi, in the castle ruins, 25 July 2006: det. calls of min. 1 foraging ind. (cf. Benda et al. 2007); castle ruins, in a fissure between beams above window, 25 January 2018: obs. \& exam. 2 우 ad torpid; - Kantara, village, 11 May 2018: det. \& rec. calls of 1 foraging ind.; - Kaplica, road and coastal habitats north of the village, 4 October 2018: det. $\&$ rec. calls of 5 foraging inds.; - Karaagaç, road and coastal habitats north of the village, 30 September 2018: det. \& rec. calls of 5 foraging inds.; - Karaagaç, forested slopes ca. $5 \mathrm{~km}$ south-west of the village, 9 May 2018: det. \& rec. calls of 2 foraging inds., 8 October 2018: det. \& rec. calls of 2 foraging inds.; Karakum, town centre, 21 January 2018: det. \& rec. calls of 1 foraging ind., 30 September 2018: det. \& rec. calls of 4-5 foraging inds.; - Karaoğlanoğlu, town, 5 October 2018: det. \& rec. calls of 4-5 foraging inds.; - Karşıyaka, village, 9 October 2018: det. \& rec. calls of 3 foraging inds.; - Karşıyaka, eastern margin of the town, 12 May 2018: det. \& rec. calls of 2-3 foraging inds., 9 October 2018: det. \& rec. calls of 3 foraging inds.; - Karşıyaka, western part of the town, 12 May 2018: det. \& rec. calls of 3 foraging inds., 5 October 2018: det. \& rec. calls of 4-5 foraging inds., 9 October 2018: det. \& rec. calls of 6 foraging inds.; - Kayalar, village, 13 May 2018: det. \& rec. calls of 1 foraging ind., 5 October 2018: det. $\&$ rec. calls of 2-3 foraging inds.; - Kayalar, coastal habitats in a resort ca. $2 \mathrm{~km}$ east of the village, 13 May 2018: det. \& rec. calls of 1 foraging ind., 5 October 2018: det. \& rec. calls of 3 foraging inds.; - Kaynakköy, village, 2 October 2018: det. \& rec. calls of 5 foraging inds.; - K1liçarslan, village, 12 May 2018: det. \& rec. calls of 2 foraging inds., 14 May 2018: det. \& rec. calls of 1 foraging ind.; - Kiliçarslan, at barracks ca. $2 \mathrm{~km}$ north of the village, 14 May 2018: det. \& rec. calls of 1 foraging ind.; - Kilitkaya, village, 10 May 2018: det. \& rec. calls of 3 foraging inds.; - Kırıkkale, village, 3 October 2018: det. \& rec. calls of 2 foraging inds.; - Kirlkkale, at the road $1 \mathrm{~km}$ east of the village, 3 October 2018: det. \& rec. calls of 2 foraging inds.; - Kırklar, road and fields $1 \mathrm{~km}$ east of the village, 10 October 2018: det. \& rec. calls of 4 foraging inds.; - Kirklar, road and fields $1 \mathrm{~km}$ north of the village, 10 October 2018: det. \& rec. calls of 2 foraging inds.; - Kirklar, road and fields $1 \mathrm{~km}$ south of the village, 10 October 2018: det. \& rec. calls of 3 foraging inds.; - Kömürcü, at the main road and fields south of the village, 9 October 2018: det. \& rec. calls of 2-3 foraging inds.; - Köprülü, village, 6 May 2018: det. \& rec. calls of 3-4 foraging inds.; - Köprülü, eastern margin of the village, 6 May 2018: det. \& rec. calls of 2 foraging inds.; - Köprülü, Köprülü göleti, lake bank, 6 May 2018: det. \& rec. calls of 4 foraging inds.; - Korüçam, eastern margin of the village, 12 May 2018: det. \& rec. calls of 2 foraging inds., 13 May 2018: det. \& rec. calls of 1 foraging ind., 14 May 2018: det. \& rec. calls of 1 foraging ind.; - Kozan, village, 12 May 2018: det. \& rec. calls of 3 foraging inds., 6 October 2018: det. \& rec. calls of 2-3 foraging inds., 9 October 2018: det. \& rec. calls of 7 foraging inds.; - Kozan, forested slope $2 \mathrm{~km}$ north-west of the village, 6 October 2018: det. $\&$ rec. calls of 1 foraging ind.; - Kumyal1, underground quarry ("Kumyalı mağaras1 I"), at the quarry entrances, 10 May 2018: det. \& rec. calls of several foraging inds.; - Kuruova, village, 6 May 2018: det. $\&$ rec. calls of 2 foraging inds.; - Lapta, town centre, 12 May 2018: det. \& rec. calls of 1 foraging ind., 9 October 2018: det. \& rec. calls of 1 foraging ind.; - Lapta, above a water reservoir at entrance of water line gallery, 12 May 2018: det. \& rec. calls of numerous foraging inds., 9 October 2018: det. \& rec. calls of numerous foraging inds.; - Lapta, western part of the town, 12 May 2018: det. \& rec. calls of 4 foraging inds., 5 October 2018: det. \& rec. calls of 4-5 foraging inds., 9 October 2018: det. \& rec. calls of 3 fora- 
ging ind.; - Lefke, above a stream at the bridge at Acendu, 15 May 2018: net. $1 q$ ad G, det. \& rec. calls of numerous foraging inds.; - Lefkoşa, old town and surrounding streets, 14 May 2018: det. \& rec. calls of numerous foraging inds.; - Lefkoşa, Göçmenköy, 14 May 2018: det. \& rec. calls of 2 foraging inds.; - Lefkoşa, Gelibolu, town, 14 May 2018: det. \& rec. calls of 3 foraging inds.; - Malatya, at a mountain spring above the village, 6 October 2018: det. \& rec. calls of several foraging inds.; - Mallıdağ, village, 8 October 2018: det. \& rec. calls of 1-2 foraging inds.; - Mallidağ, western margin of the village, 7 May 2018: det. \& rec. calls of 1 foraging ind., 8 October 2018: det. \& rec. calls of 2-3 foraging inds.; - Margo, at abandoned farm and barracks, 10 October 2018: det. \& rec. calls of several foraging inds.; - Margo, at the road ca. $1.5 \mathrm{~km}$ north of the abandoned barracks, 10 October 2018: det. \& rec. calls of several foraging inds.; - Mersinlik, road and coastal habitats $2 \mathrm{~km}$ north of the village, 4 October 2018: det. \& rec. calls of 1-2 foraging inds.; - Mersinlik, road and coastal habitats ca. $5 \mathrm{~km}$ north-east of the village, 4 October 2018: det. \& rec. calls of 2 foraging inds.; - Ötüken, at a resort $6 \mathrm{~km}$ north-east of the village, 6 May 2018: det. \& rec. calls of 2 foraging inds.; - Ozanköy, town, 8 October 2018: det. \& rec. calls of 4 foraging inds.; - Ozanköy, northern part of the town, 30 September 2018: det. \& rec. calls of 5 foraging inds.; - Özhan, village, 12 May 2018: det. \& rec. calls of 1 foraging ind., 14 May 2018: det. \& rec. calls of 1 foraging inds.; - Pamuklu, village, 10 May 2018: det. \& rec. calls of 2 foraging inds.; - Paşaköy, eastern part of the village, 3 October 2018: det. \& rec. calls of 1 foraging ind.; - Paşaköy, western part of the village, 3 October 2018: det. \& rec. calls of 4 foraging inds., 10 October 2018: det. \& rec. calls of 4-6 foraging inds.; - Pınarbaş1, village, 14 May 2018: det. \& rec. calls of 1 foraging ind.; - Pınarbaş1, eastern margin of the village, 9 October 2018: det. \& rec. calls of 2 foraging inds.; - Pinarl1, village, 10 October 2018: det. \& rec. calls of 2 foraging inds.; - P1narl1, road and fields $1 \mathrm{~km}$ north-east of the village, 10 October 2018: det. \& rec. calls of 1 foraging ind.; - Sadra- zamköy, village, 13 May 2018: det. \& rec. calls of 2 foraging inds., 5 October 2018: det. \& rec. calls of 3 foraging inds.; - Sadrazamköy, above a water reservoir next to a beach resort, 13 May 2018: net. 1 ad, det. \& rec. calls of numerous foraging inds., 5 October 2018: det. \& rec. calls of numerous foraging inds.; - Sadrazamköy, coastal habitats 4 km east of the village, 13 May 2018: det. \& rec. calls of 2 foraging inds., 5 October 2018: det. \& rec. calls of 1 foraging ind.; - Sazlıköy, village, 10 May 2018: det. \& rec. calls of 1 foraging ind.; - Serdarl1, village, 7 May 2018: det. \& rec. calls of 2 foraging inds.; - Serdarl1, southern margin of the village, 7 May 2018: det. \& rec. calls of 2 foraging inds.; - Sınırüstü, northern margin of the village, 6 May 2018: det. \& rec. calls of 1 foraging ind.; - Sinırüstü, road $1 \mathrm{~km}$ east of the village, 6 May 2018: det. \& rec. calls of 1 foraging ind., 11 May 2018: det. \& rec. calls of 1 foraging ind.; - Sipahi, coastal habitats and road ca. $5 \mathrm{~km}$ east of the village at the Agios Therissos church, 4 Ocotober 2018: det. \& rec. calls of several foraging inds.; - Sipahi, coastal habitats and road ca. $1 \mathrm{~km}$ west of the Agios Therissos church, 4 October 2018: det. \& rec. calls of several foraging inds.; - Sipahi, coastal habitats ca. $2 \mathrm{~km}$ north of the village, 4 October 2018: det. \& rec. calls of 4-5 foraging inds.; - Sipahi, road and fields $1 \mathrm{~km}$ north-west of the village, 4 October 2018: det. \& rec. calls of 2 foraging inds.; - Şirinevler, northern margin of the village, 12 May 2018: det. \& rec. calls of 4 foraging inds., 14 May 2018: det. \& rec. calls of 4 foraging inds., 9 October 2018: det. \& rec. calls of 3 foraging inds.; - Şirinevler, road and fields ca. $1 \mathrm{~km}$ south of the village, 12 May 2018: det. \& rec. calls of 1 foraging ind.; - Sourp Magar, forested slope above the monastery ruins, 2 October 2018: det. \& rec. calls of 1 foraging ind.; - Sütlüce, northern margin of the village, 10 October 2018: det. \& rec. calls of 3 foraging inds.; - Taşpınar, village, 5 October 2018: det. \& rec. calls of 5 foraging inds.; - Tatlısu, village, 4 October 2018: det. \& rec. calls of 4 foraging inds.; - Tatlisu, northern margin of the village, 4 October 2018: det. \& rec. calls of 3-4 foraging inds.; - Tatlisu, at the main road north-west of the village, 30 September 2018: det. \& rec. calls of 10 foraging inds., 4 October 2018: det. \& rec. calls of 2-3 foraging inds.; - Tatlısu, Yal1, 3 October 2018: det. \& rec. calls of 4 foraging inds.; - Tepebaş1, at the barracks $1 \mathrm{~km}$ west of the village, 6 October 2018: det. \& rec. calls of 6 foraging inds.; - Tepebaş1, road and forest $3 \mathrm{~km}$ south of the village, 6 October 2018: det. \& rec. calls of 1 foraging ind.; - Tirmen, village, 7 May 2018: det. \& rec. calls of 1 foraging ind., 8 October 2018: det. \& rec. calls of 3 foraging inds.; - Tirmen, forested slope ca. $1 \mathrm{~km}$ north-west of the village, 8 October 2018: det. \& rec. calls of 1 foraging ind.; - Topçuköy, southern part of the village, 11 May 2018: det. \& rec. calls of 3 foraging inds.; - Türkeli, eastern margin of the village, 9 October 2018: det. \& rec. calls of 3 foraging inds.; - 
Türkmenköy, village, 3 October 2018: det. \& rec. calls of 2 foraging inds.; - Türkmenköy, road and fields ca. $1 \mathrm{~km}$ east of the village, 6 May 2018: det. \& rec. calls of 3 foraging inds.; - Türkmenköy, road and fields ca. $3 \mathrm{~km}$ north-east of the village, 6 May 2018: det. \& rec. calls of 3 foraging inds., 3 October 2018: det. \& rec. calls of 1 foraging ind.; - Turnalar, village, 11 May 2018: det. \& rec. calls of 3 foraging inds.; - Ulukışla, village, 10 October 2018: det. \& rec. calls of 4 foraging inds.; - Ulukışla, road and fields ca. $2 \mathrm{~km}$ north-east of the village, 10 October 2018: det. \& rec. calls of 5-7 foraging inds.; - Vadili, village, 3 October 2018: det. \& rec. calls of 2-3 foraging inds.; - Vadili, road and fields ca. 2 km north-west of the village, 3 October 2018: det. \& rec. calls of 4 foraging inds.; - Vadili, north-western margin of the village, 3 October 2018: det. \& rec. calls of 4 foraging inds.; - Yamaçköy, village, 7 May 2018: det. \& rec. calls of 2 foraging inds.; - Yarköy, village, 11 May 2018: det. \& rec. calls of 1-2 foraging inds.; - Yarköy, southern margin of the village, 11 May 2018: det. \& rec. calls of 1 foraging ind.; - Yayla, village, 7 October 2018: det. \& rec. calls of 2 foraging inds.; - Yayla, road and fields ca. $3 \mathrm{~km}$ south-east of the village, 7 October 2018: det. \& rec. calls of 2 foraging inds.; - Yayla Tepe, forested southern slope of the peak, 2 October 2018: det. \& rec. calls of 1-2 foraging inds.; - Yedidalga, village, 15 May 2018: det. \& rec. calls of numerous foraging inds.; - Yedikonuk, Giouti Burnu, cliff ca. $2 \mathrm{~km}$ north of the village, 4 October 2018: det. \& rec. calls of 3 foraging inds.; - Yedikonuk, Giouti Burnu, at a cliff above road ca. $5 \mathrm{~km}$ north-east of the village, 4 October 2018: det. \& rec. calls of 3 foraging inds.; - Yeni Erenköy, village, 4 October 2018: det. \& rec. calls of 5-7 foraging inds.; - Yeni Erenköy, north-eastern margin of the village, 4 October 2018: det. \& rec. calls of 4 foraging inds.; - Yeni Erenköy, south-western margin of the village, 4 October 2018: det. \& rec. calls of 5 foraging inds.; - Yeşilırmak, village, 15 May 2018: det. \& rec. calls of several foraging inds.; - Yeşilköy, village, 4 October 2018: det. \& rec. calls of 2-3 foraging inds.; Yeşilköy, southern margin of the village, 4 October 2018: det. \& rec. calls of 3 foraging inds.; - Yeşilköy, road and fields $2 \mathrm{~km}$ north of the village, 4 October 2018: det. \& rec. calls of 4 foraging inds.; - Yeşiltepe, town, 5 October 2018: det. \& rec. calls of 1 foraging ind.; - Yeşilyurt, western margin of the village, 15 May 2018: det. \& rec. calls of 5 foraging inds.; - Yiğitler, village, 3 October 2018: det. \& rec. calls of

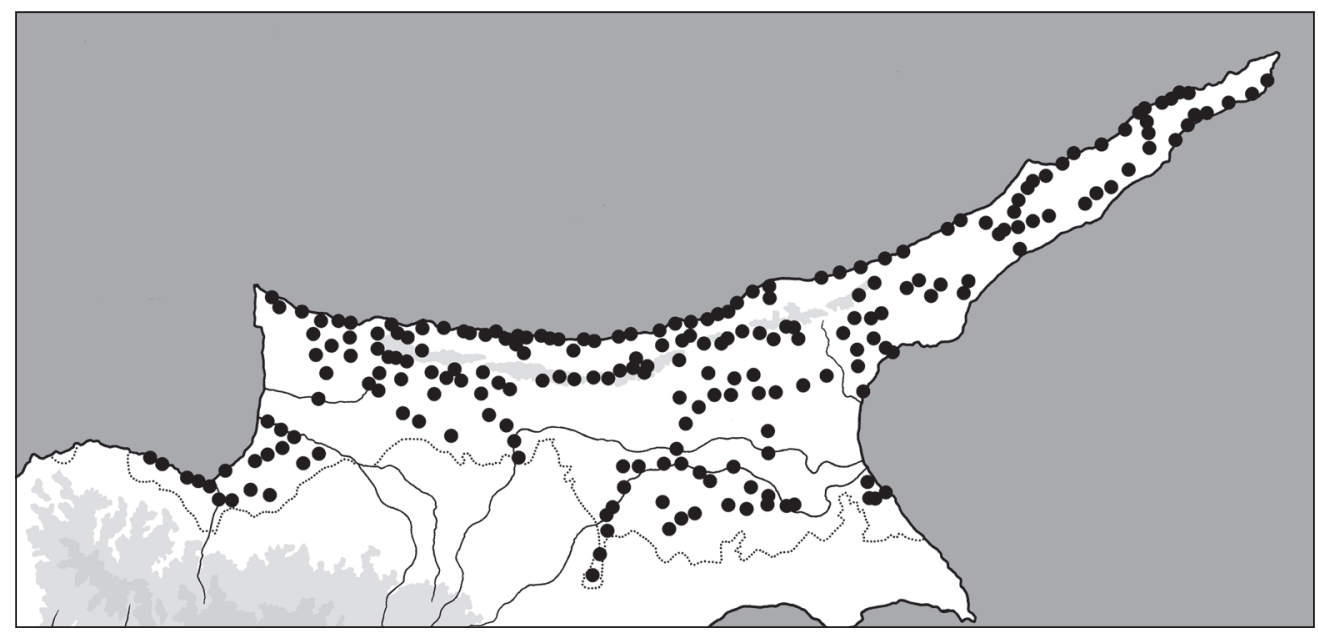

Fig. 20. Records of Kuhl's bat (Pipistrellus kuhlii) in Northern Cyprus; for the map legend see Fig. 1, some symbols may represent more than one record site.

Obr. 20. Nálezy netopýra vroubeného (Pipistrellus kuhlii) na Severním Kypru; vysvětlivky mapy viz obr. 1, některé symboly mohou představovat více než jednu nálezovou lokalitu. 
5 foraging inds.; - Yiğitler, eastern margin of the village, 3 October 2018: det. \& rec. calls of 3-5 foraging inds.; - Yiğitler, western margin of the village, 3 October 2018: det. \& rec. calls of 2 foraging inds.; Y1lmazköy, village, 12 May 2018: det. \& rec. calls of 1 foraging ind.; - Yukarı Dikmen, village, 2 October 2018: det. \& rec. calls of 2 foraging inds.; - Zeybekköy, village, 10 May 2018: det. \& rec. calls of 1 foraging ind.; - Zeytinlik, northern part of the town, 5 October 2018: det. \& rec. calls of 4 foraging inds.; - Ziyamet, village, 10 May 2018: det. \& rec. calls of 4 foraging inds. - Published data: near Akanthou [= Tatlisu], northern shore, 1 ind. (mummy) (SPITZENBERGER 1979); - [Beylerbeyi,] Bellapais, monastery ruins, 9 August 1988: 1 ind. (Opstaele 1990); - Boghaz [= Bogazi] (Famagusta), April 1990: sightings (Boye et al. 1990); - Famagusta [= Gazimağusa], old town, columnes of Venice Palace, March 1989: a colony (Boye et al. 1990); wall crevices and behind a board of a house near the old land gate, March 1989: a colony (Boye et al. 1990); - Kyrenia [= Girne], harbour, March 1989: sightings (Boye et al. 1990).

Kuhl's bat (Pipistrellus kuhlii) is by far the most frequently recorded bat species in Northern Cyprus, documented at 265 localities (Fig. 20), i.e. P. kuhlii records represent almost two thirds $(58.6 \%)$ of all bat records in the country (see Table 1$)$. This dominance is in accordance with the occurrence pattern of this bat in other countries of the eastern Mediterranean, see BENDA \& HorÁČEK (1998) and BENDA et al. (2006, 2009, 2010, 2014, 2016). Sites where echololocation calls were detected and mostly also recorded (262) constituted the majority of records of $P$. kuhlii in Northern Cyprus, while foraging individuals were netted at only four sites, and roosting bats were found at five sites (at most of the netting and roosting sites the calls of this bat were also detected). P. kuhlii is the dominant bat species in most areas of Northern Cyprus and its calls were found in $67.5 \%$ of the bat call recordings made in May and October 2018 (2,980 sequences of $P$. kuhlii, 4,413 sequences of all bat calls, including those not identifiable to the species level). The altitudinal distribution of $P$. kuhlii in Northern Cyprus covers the maximum range found in bats ( $882 \mathrm{~m}$, see Table 2 ); nevertheless, this bat is predominantly a lowland inhabiting species - the altitude median is $78 \mathrm{~m}$ a. s. 1 . The foraging individuals or even groups of $P$. kuhlii were detected in all habitats of the country, and were documented as most abundant at settlements (of all sizes), in open agricultural landscapes and at wetlands, but also in forested mountains. However, although calls of this bat were also detected in the forests of Yayla Tepe at ca. $885 \mathrm{~m}$ a. s. 1., the highest bat locality in the country, they constituted only an accesoric component of the foraging community, and were highly outnumbered by the calls of Pipistrellus pipistrellus. A similar distribution pattern of $P$. kuhlii was also found in the southern part of Cyprus, see BENDA et al. (2007). The roosts of this species in Northern Cyprus were found to be solely the fissures among the stones of historical monuments (see also BENDA et al. 2007).

\section{Nyctalus leisleri (Kuhl, 1817)}

ReCords. Original data: Gazimağusa, Çanakkale Göleti, at the lake, 6 May 2018: det. \& rec. calls of 1 foraging ind., 8 May 2018: det. \& rec. calls of 2 foraging inds.

The lesser noctule bat (Nyctalus leisleri) is reported here for the first time from Northern Cyprus. Its echolocation call was repeatedly recorded in the wetland landscape at Çanakkale Göleti lake, west of Gazimağusa, at ca. $5 \mathrm{~m}$ a. s. 1. (Fig. 21). These findings in the lowland are in sharp contrast to the previous two records of $N$. leisleri from the island, which were restricted to the highest and well forested parts of the Troodos Mts., both at altitudes above 1,500 m a. s. 1. (BENDA et al. 2007). These mountain records were made in April, July and October and such a temporal distribution of records indicates a permanent occurrence of this migratory bat species on the island (BENDA et al. 2007). However, no presence of $N$. leisleri was detected at 


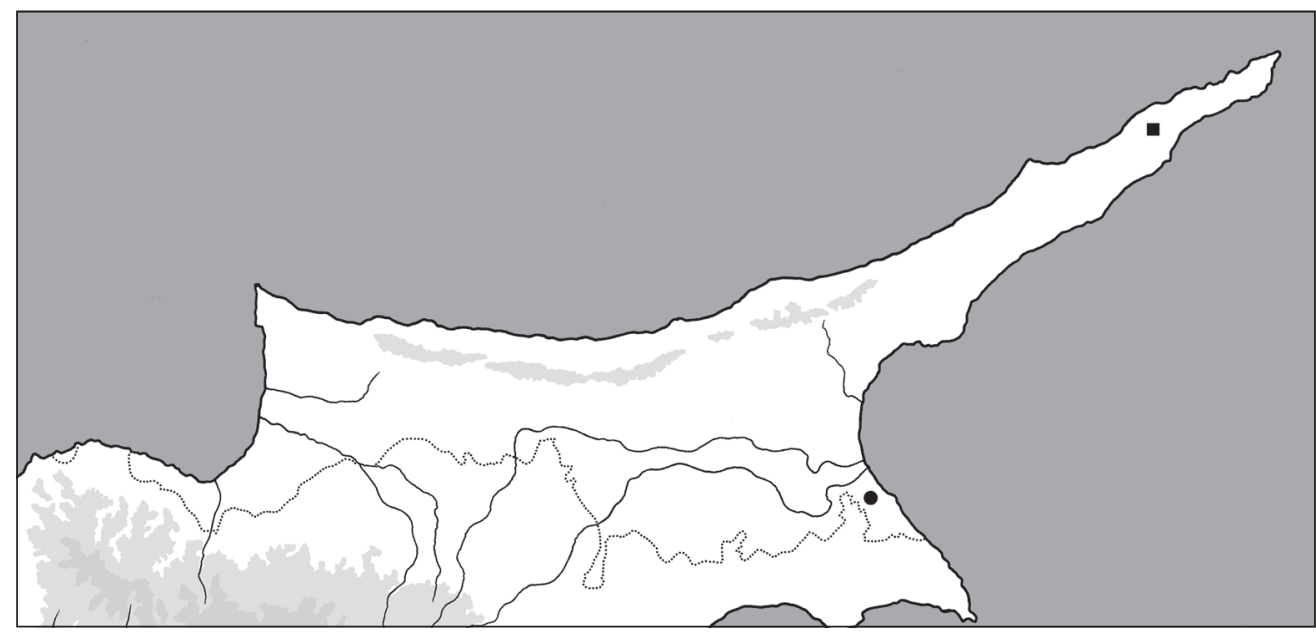

Fig. 21. Records of the lesser noctule bat (Nyctalus leisleri) (circle) and the greater noctule bat (Nyctalus lasiopterus) (square) in Northern Cyprus; for the map legend see Fig. 1.

Obr. 21. Nálezy netopýra stromového (Nyctalus leisleri) (kroužek) a netopýra obrovského (Nyctalus lasiopterus (čtverec) na Severním Kypru; vysvětlivky mapy viz obr. 1.

similar habitats in the Beşparmak (Kyrenia) range in Northern Cyprus. The permanent occurrence of this bat in Cyprus is perhaps restricted to the Troodos Mts. and only occasionally it forages out of the forested mountain areas. On the other hand, in Crete, where $N$. leisleri was found a rare member of the island bat fauna (BENDA et al. 2009), it was recorded at much lower altitudes than in Cyprus, in the range of 240-600 m a s 1 . (mean $381.7 \mathrm{~m}$, median $305.0 \mathrm{~m}$ ). This may indicate that a part of the regular occurrence area of $N$. leisleri in Cyprus could also be at medium height altitudes of the central mountain range, which could better connect the recorded occurrence at Çanakkale lake.

\section{Nyctalus lasiopterus (Schreber, 1780)}

RECORD. Original data: Dipkarpaz, village, 1 October 2018: det. \& rec. calls of 1 foraging ind.

The greater noctule bat (Nyctalus lasiopterus) is reported here for the first time from Northern Cyprus. This report is based on a single recorded sequence of an echolocation call of an individual flying over the village of Dipkarpaz in autum (Fig. 21). Such a finding suggests the possibility of a migratory individual, and perhaps a vagrant visitor. However, the only previous record of $N$. lasiopterus from Cyprus consisted of four adult females and four young netted at one occasion in a forested part of Southern Cyprus in July 2006 (BENDA et al. 2007) and this finding most probably represented a late record of a maternity group (two of four adult females were still lactating). The only two findings of this bat species from southern Anatolia (Y IĞIT et al. 2008, ARSLAN et al. 2015) probably also represented reproduction aggregations, as they were composed of several bats collected at (supposedly) one occasion. The single record site in Northern Cyprus interconnects the three closest localities, being distant for $175 \mathrm{~km} \mathrm{NE}$ of 
Vretsia in Southern Cyprus (Benda et al. 2007), 235 km SW of Gökçedam (Osmaniye Province, Turkey; Arslan et al. 2015) and 425 km SW of Elmali (Antalya Province, Turkey; YıĞIT et al. 2008). Whether the finding of $N$. lasiopterus in Northern Cyprus represents an indication of a permanent but extremely rare occurrence there (as was suggested by the only previous evidence on the island) or only a temporal or even accidental presence, remains to be shown by further research. Nevertheless, as the call of the greater noctule bat was found only in one sequence among almost 4,500 other recorded call sequences, this bat is certainly extremely rare in Northern Cyprus.

\section{Plecotus kolombatovici Đulić, 1980}

RECORDS. Original data: Ağırdağ, at a cleft cave ca. $1 \mathrm{~km}$ west of the village [1], 5 April 2005: net. 1 ad (cf. Benda et al. 2007); - Alevkaya, Küpo mağaras1 [2], at the cave entrance, 2 October 2018: net. 1 $\hat{~}$ ad; - Pınarbaş1 [3], village, 9 October 2018: det. \& rec. call. of 1 foraging ind. of Plecotus sp.

Kolombatović's long-eared bat (Plecotus kolombatovici) is a rare bat in Northern Cyprus, where its distribution is confined to higher altitudes (Table 2). An individual was netted twice at the entrance of a cave in the Beşparmak (Kyrenia) range (at $540 \mathrm{~m}$ and $702 \mathrm{~m}$ a. s. 1., respectively) and a call of a foraging Plecotus was detected once around street lamps in a village on the slope of this ridge at $334 \mathrm{~m}$ a. s. 1. (Fig. 22). The altitudes of these sites indicate this bat as the 'most mountainous' bat species in Northern Cyprus (Fig. 3). The affinity of P. kolombatovici to high situated habitats in Cyprus was also demostrated by BENDA et al. (2007) and indirectly by Boye et al. (1990). This also conforms with the situation in Crete (BENDA et al. 2009). On the other hand, in southern Turkey and in the Balkans, inluding many islands, this bat occurs mostly at low altitudes close to the sea shore and only exceptionally was found at high altitudes

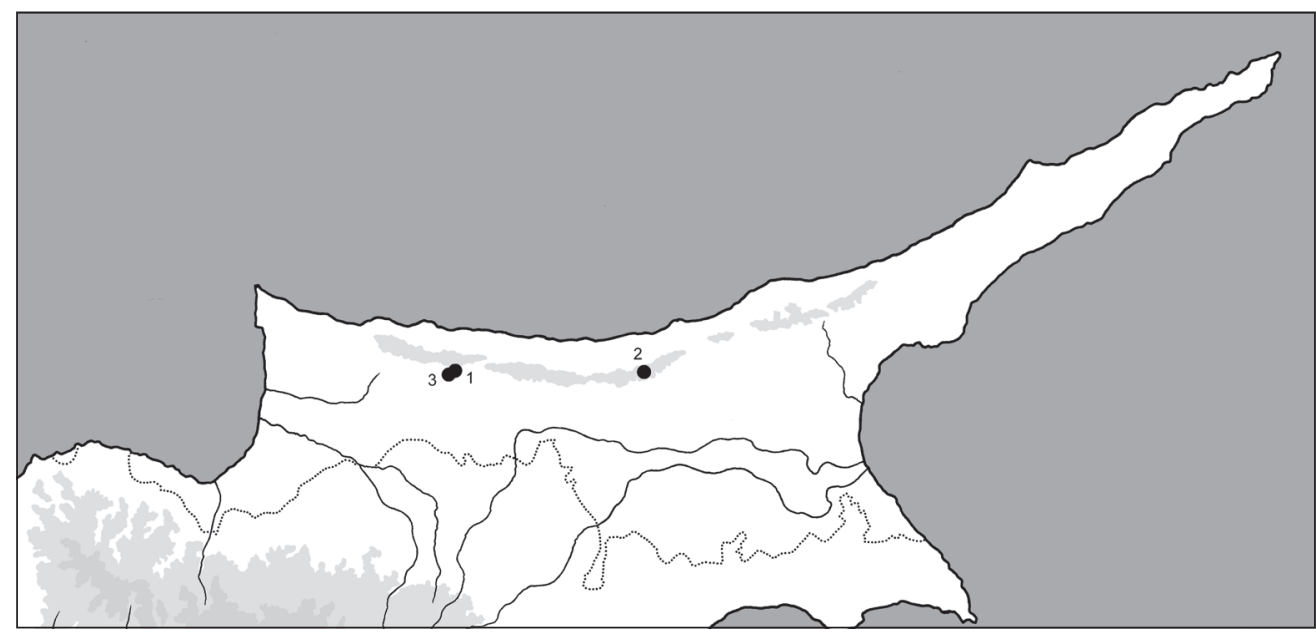

Fig. 22. Records of Kolombatović's long-eared bat (Plecotus kolombatovici) in Northern Cyprus; for the map legend see Fig. 1.

Obr. 22. Nálezy ušana balkánského (Plecotus kolombatovici) na Severním Kypru; vysvětlivky mapy viz obr. 1. 
(Kiefer \& von Helversen 2004, Tvrtković et al. 2005, Benda \& Uhrin 2017, Sachanowicz \& Ciechanowski 2018). Thus, in the large eastern Mediterranean islands, P. kolombatovici shows a certain shift in the species' ecology in comparison to its environmental preferences in its more northern distribution range.

\section{Miniopterus schreibersii (Kuhl, 1817)}

ReCords. Original data: Çamlıbel, an orchard $2.5 \mathrm{~km}$ north-west of the village [1], 12 May 2018: det. $\&$ rec. calls of 1 foraging ind.; - Kalkanl, olive grove reserve [2], at a water reservoir, 16 May 2018: det. $\&$ rec. calls of 1-2 foraging inds.; - Lapta, at a water gallery entrance and at a water reservoir [3], 12 May 2018: det. \& rec. calls. of 1-2 foraging inds., 9 October 2018: det. \& rec. calls of 1 foraging ind.; - Lefke, above a stream at the bridge at Acendu [4], 15 May 2018: det. \& rec. calls of numerous foraging inds.

BENDA et al. (2007) demostrated Schreibers' bent-winged bat (Miniopterus schreibersii) to be a rather rare, but stable component of the Cypriot fauna and perhaps the same is valid for Northern Cyprus. Since all previous six records of this bat were reported from the southern part of Cyprus, M. schreibersii is reported here for the first time from Northern Cyprus. All four new records were made in the western part of the country (Fig. 23) at low altitudes (altitude median $95.0 \mathrm{~m}$, mean $125.3 \mathrm{~m}$ a. s. 1.) and from a very small range of altitudes (smallest among all bat species, see Table 2, Fig. 3). All new findings of $M$. schreibersii comprise recordings of calls, while no roost or netting records are available; however, only the record at Lefke (Fig. 24) is represented by a series of more than 300 recorded sequences, while at other sites only 1-2 foraging individuals were recorded. The foraging site at Lefke with the documented dense foraging community of M. schreibersii is situated ca. $16 \mathrm{~km}$ north and directly under the mountain valley

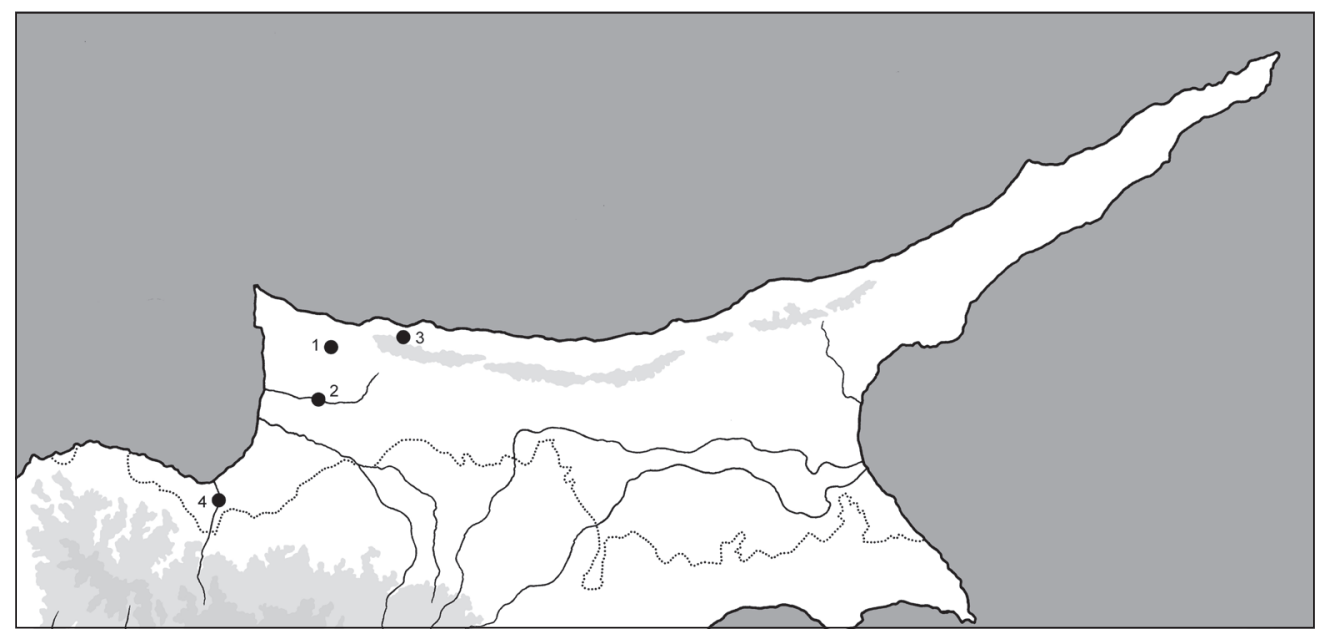

Fig. 23. Records of Schreibers' bent-winged bat (Miniopterus schreibersii) in Northern Cyprus; for the map legend see Fig. 1.

Obr. 23. Nálezy létavce evropského (Miniopterus schreibersii) na Severním Kypru; vysvětlivky mapy viz obr. 1. 

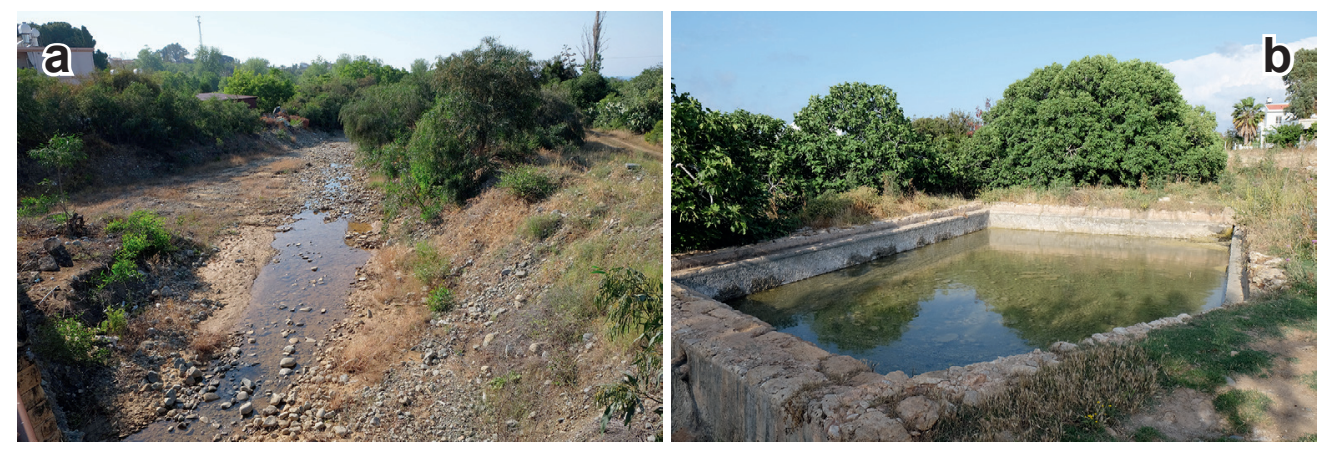

Fig. 24. Two sites of netting and detectoring of the foraging bat communities in Northern Cyprus; $a-a$ stream bed at Acendu, a part of the Lefke town, a foraging site of four bat species, $b$ - an irrigation reservoir next to a beach resort, north-west of Sadrazamköy, a foraging site of five bat species.

Obr. 24. Dvě lokality Severního Kypru, na kterých probíhal odchyt do sítě a detekce hlasů lovících společenstev netopýrů; a - koryto potoka v Acendu, součásti města Lefke, místo lovu čtyř druhů netopýrů, b - zavlažovací nádrž vedle plážového letoviska severozápadně od vsi Sadrazamköy, místo kde lovilo pět netopýríích druhů.

of Kakopetria, where a colony of up to ca. 250 individuals was found to roost in an abandoned mine gallery (BENDA et al. 2007). The presence of numerous foraging bats at Lefke could be connected to the Kakopetria roost and maybe other records in Northern Cyprus could be linked to the Troodos population too as they are all in relatively close proximity to it. Although the relative rarity of $M$. schreibersii in Cyprus is in contrast to the rather common occurrence of this bat in southern Turkey and the western Levant (BENDA \& HoRÁČEK 1998, BENDA et al. 2006, 2016), it more or less conforms to the situation in Crete, where this bat belongs among the medium frequently recorded bat species (BENDA et al. 2009).

\section{Tadarida teniotis (Rafinesque, 1814)}

RECORDS. Original data: Ağırdağ, at a cliff above the village [1], 2 May 2009: det. calls of 1 foraging ind.; - Kalkanl1, olive grove reserve [2], 16 May 2018: det. \& rec. calls of 1 foraging ind.; - Kozan, in the slope $2 \mathrm{~km}$ north-west of the village [3], 6 October 2018: det. calls of 1 foraging ind.; - Yedikonuk, Giouti Burnu [4], a cliff above road, ca. $2 \mathrm{~km}$ north-east of the village, 13 November 2015: det. calls of 5 inds. emerging from the cliff fissures. - Published data: Kyrenia range [= Beşparmak Dağları] [5], March 1989: calls of cf. T. teniotis (BoyE et al. 1990).

The European free-tailed bat (Tadarida teniotis) is a rather rare bat in Northern Cyprus with its echolocation calls detected at only five sites (Fig. 25), including one record associated with bats emerging their roosts in a cliff high above the sea coast. As already stressed by BENDA et al. (2007), the scarcity of records of T. teniotis in Cyprus is reminiscent of the situation in the Mediterranean Levant, where records of this bat are infrequent despite numerous suitable habitats (BENDA et al. 2006, 2016). On the other hand, it is in sharp contrast with its occurrence in Crete, where this bat is by far the most frequently recorded bat, known from more than a hundred sites (BENDA et al. 2009). Similarly as in the southern part of Cyprus (see BENDA et al. 2007), 


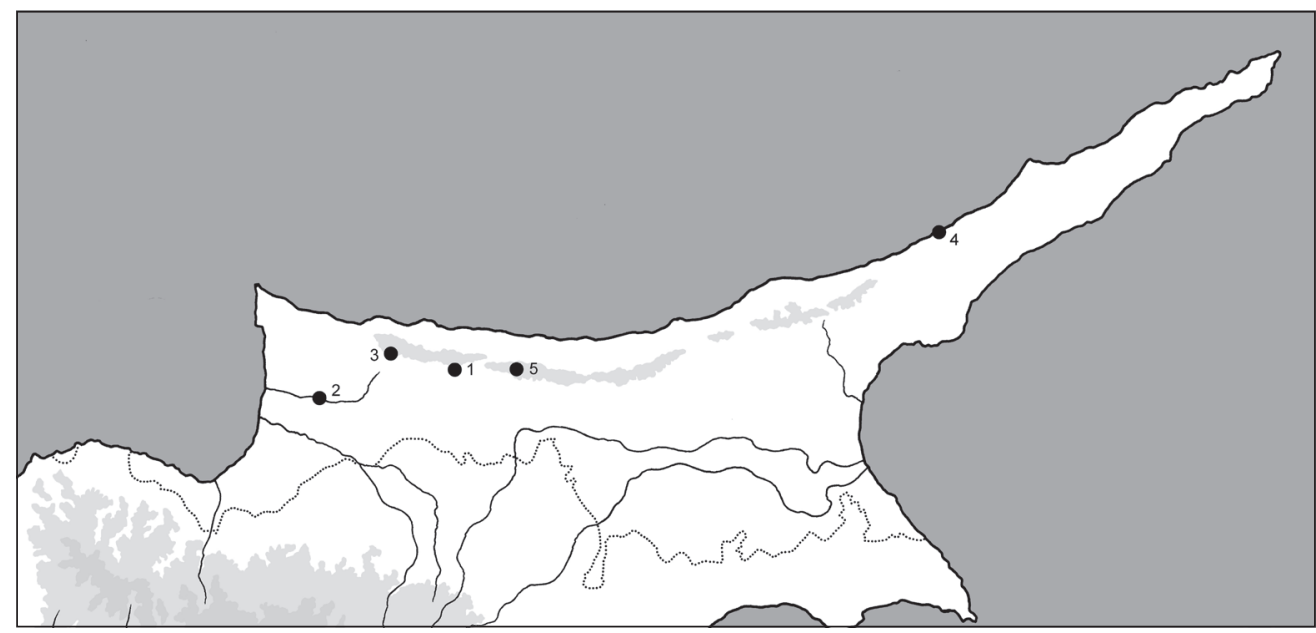

Fig. 25. Records of European free-tailed bat (Tadarida teniotis) in Northern Cyprus; for the map legend see Fig. 1.

Obr. 25. Nálezy morouse evropského (Tadarida teniotis) na Severním Kypru; vysvětlivky mapy viz obr. 1.

in Northern Cyprus T. teniotis was recorded at medium height or high situated localities, that makes this species the second 'most mountainous' bat of the island (Table 2, Fig. 3).

\section{CONCLUSIONS}

The present review summarises at least 450 records of 20 bat species available from Northern Cyprus (Table 1). Most of these records were made during recent surveys during which the number of records increased elevenfold and the number of species by 1.5 times compared to the numbers reviewed by BENDA et al. (2007) and AşAN BAYDEMIR (2014). In comparison with this last list of the Cypriot bat fauna, seven species are reported here to occur in Northern Cyprus for the first time (Table 1). One of these, Rhinolophus euryale, questionably suggested to inhabit the southern part of Cyprus by Boye et al. (1990), is confirmed here as a true member of the island fauna. Since no records of Myotis capaccinii and Nyctalus noctula were made during the recent survey, the occurrence of these bats, previously reported by Kock (1974) and Spitzenberger (1979), respectively, and questioned by Benda et al. (2007), remain improbable on the island. Two bat species, Rhinolopus mehelyi and Eptesicus anatolicus, remain being reported only from the northern part of the island, with one individual per species, while all bat species known to exist in the southern part of the island, are now confirmed to exist in the northern part of Cyprus too.

As stated by BENDA et al. (2007), the known bat list of Cyprus covers almost all faunal elements to be expected to inhabit the island. Out of the fauna of the Mediterranean arboreal zone of the eastern Mediterranean (BENDA \& HorÁČEK 1998, BENDA et al. 2006, 2009, 2016), only the greater mouse-eared bat (Myotis myotis), Bechstein's bat (Myotis bechsteinii), whiskered bat (Myotis mystacinus s.1.), and the Alpine long-eared bat (Plecotus macrobullaris) (besides 

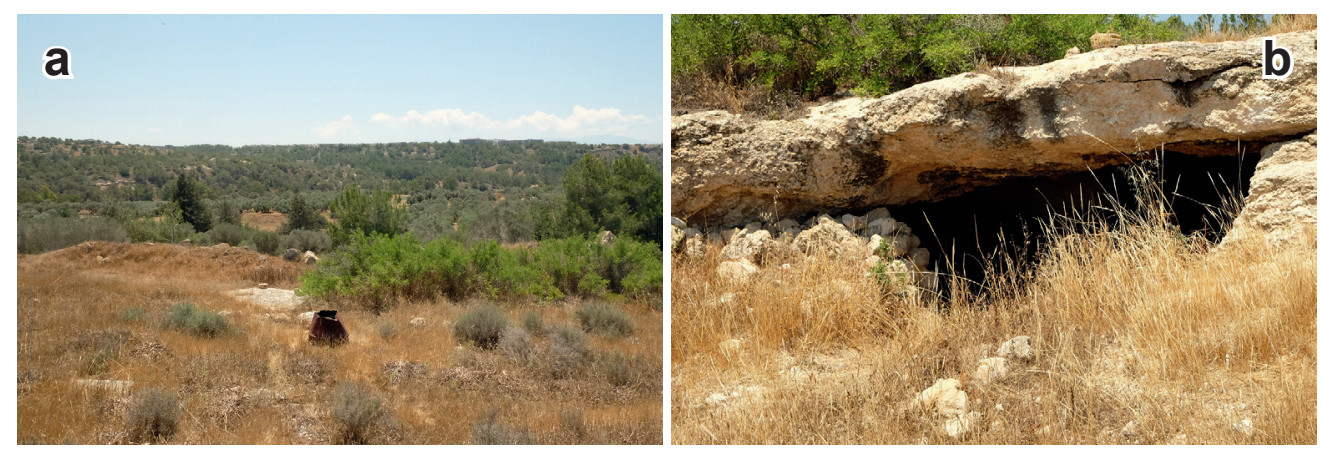

Fig. 26. Olive grove reserve at Kalkanl, area where twelve bat species were recorded, the highest diversity in one site in Northern Cyprus; $a$ - general view of the locality, b - view of the entrance of the "Çoban mağarası", an ancient underground quarry.

Obr. 26. Reservace olivového háje u Kalkanl1, ve které bylo zaznamenáno 12 druhů netopýrů, tedy místo s nejvyšší diversitou na Severním Kypru; a - celkový pohled na háj, b - vchod do starého podzemního lomu, zvaného "jeskyně Çoban”.

the two problematic species mentioned above, $N$. noctula and $M$. capaccinii) were not found in Cyprus. Moreover, M. mystacinus (s.1.), M. capaccinii and P. macrobullaris are known not only from the areas adjacent to the coast of the Levantine Sea, but also from Crete (BENDA et al. 2009). On the other hand, two Cypriot species, Myotis nattereri and Nyctalus lasiopterus were not confirmed from Crete. These differences suggest diverse colonisation histories of these two similarly sized islands of the eastern Mediterranean. For other details concerning the composition of the bat fauna of Cyprus see BENDA et al. (2007).

The occurrence of bats was documented throughout the whole area of Northern Cyprus (see e.g. Fig. 20) and all examined habitats were found to host certain bat species. However, a high diversity of the bat fauna in Northern Cyprus is mostly linked with (relatively) undisturbed habitats and/or with underground spaces. Sites, where seven or more (i.e. at least one third) of the Cypriot bat species spectrum were documented, are equally distributed across a large part of the altitude range of the country (12-702 $\mathrm{m}$ a. s. 1., mean $329.4 \mathrm{~m}, \mathrm{n}=7)$. The highest bat diversity, with twelve species - more than a half of the bat fauna - was documented in the olive grove reserve at Kalkanlı (Fig. 26), where a relatively undisturbed area (with very extensive or no agriculture) is complemented with an ancient underground quarry ("Çoban cave") and a water body, i.e. good roosting and foraging opportunities; while most bats just foraged at the site, two species were found both roosting and foraging there. The second highest diversity, with nine bat species, was discovered at the underground quarry near Kumyalı ("Kumyalı cave", Fig. 4), while eight species were found at three sites - at entrances of the Küpo cave, İçirli cave, and Lapta water gallery (Figs. 8, 9). Seven bat species were found at two sites, Sicak cave and the mountain spring above Malatya (Fig. 15) - of the seven mentioned localities, only the latter one does not represent any (obvious) natural or artificial underground, just a small pool at a spring in the mountains, surrounded by a rather neglected orchard with several abandoned buildings and with a forest nearby. At all these sites, rich communities combining cave dwelling bats with litophilous or dendrophilous species as well as aerial hawkers with foliage gleaners (plus 
one frugivorous bat) were documented, viz. Pipistrellus kuhlii at all seven sites, Rhinolophus ferrumequinum and $R$. hipposideros at six sites, Rousettus aegyptiacus, Rhinolophus blasii, Myotis nattereri, and Pipistrellus pipistrellus at five sites, R. euryale at four sites, Myotis blythii, M. emarginatus, and Pipistrellus pygmaeus at three sites, and other five species only additionally at some of these localities. These localities are very variable in their environments and probably have no general common characteristics - while three of them (currently) represent rather undisturbed habitats in mountains (Küpo cave, Malatya spring, S1cak cave; Figs. 9, 15), one site lies next to an active quarry near the sea shore (Kumyalı quarry) and another one is in a disturbed area, within an urban habitat (Lapta water gallery, Fig. 9). Effective conservation issues for bats in Northern Cyprus thus have to consider not only the general legal protection of all bat species and their habitats, but also a more strict protection of selected sites, combining both roost opportunities and foraging grounds. Bats were consistently found in small caves and karst features of $<30 \mathrm{~m}$ length and at variable elevations, demonstrating the critical importance of conserving caves and karst features in large zones across the Beşparmak (Kyrenia) mountain range known to have bat records, rather than focusing conservation on specific hibernacula. The presented review can help to choose some possibilities.

\section{SOUHRN}

V př́spěvku je předložen kompletní soupis nálezů netopýrů známých ze Severního Kypru; je založen jednak na rešerši nemnohých literárních údajů a jednak na nových nálezech pocházejících především z nedávného terenního výzkumu, jehož nejintensivnější část proběhla roku 2018. Přehledy nálezů jednotlivých druhů jsou doplněny mapkami a zhodnoceními rozšiřrení v kontextu celého ostrova, př́íp. okolních oblastí Blízkého východu. Ze severního státu na ostrově Kypr je k disposici nejméně 451 nálezů (druh/lokalita) celkem 21 druhu netopýrů - 26 nálezů kaloně egyptského (Rousettus aegyptiacus), 19 nálezů vrápence velkého (Rhinolophus ferrumequinum), 21 nálezů vrápence malého (Rhinolophus hipposideros), pět nálezů vrápence středozemského (Rhinolophus euryale), jeden nález vrápence Mehelyova (Rhinolophus mehelyi), 12 nálezů vrápence Blasiova (Rhinolophus blasii), čtyři nálezy netopýra východního (Myotis blythii), 10 nálezů netopýra řasnatého (Myotis nattereri), tři nálezy netopýra brvitého (Myotis emarginatus), jeden nález netopýra dlouhonohého (Myotis capaccinii), pět nálezů netopýra večerního (Eptesicus serotinus), jeden nález netopýra anatolského (Eptesicus anatolicus), šest nálezů netopýra Saviova (Hypsugo savii), 50 nálezů netopýra hvízdavého (Pipistrellus pipistrellus), devět nálezů netopýra nejmenšího (Pipistrellus pygmaeus), 265 nálezů netopýra vroubeného (Pipistrellus kuhlii), jeden nález netopýra stromového (Nyctalus leisleri), jeden nález netopýra obrovského (Nyctalus lasiopterus), tři nálezy ušana balkánského (Plecotus kolombatovici), čtyři nálezy létavce evropského (Miniopterus schreibersii) a pět nálezů morouse evropského (Tadarida teniotis). Celkový počet nálezů netopýrů na Severním Kypru vzrostl oproti poslednímu publikovanému přehledu (BENDA et al. 2007) 11×, počet druhů netopýrů $1,5 \times$. Sedm druhů netopýrů (Rhinolophus euryale, Myotis emarginatus, Pipistrellus pipistrellus, P. pygmaeus, Nyctalus leisleri, N. lasiopterus a Miniopterus schreibersii) je zde uváděno ze Severního Kypru poprvé, přičemž nesporné nálezy vrápence středozemského (Rhinolophus euryale) jsou zde uváděny vůbec poprvé z celého ostrova Kypru. S výjimkou netopýra rezavého (Nyctalus noctula), jehož nejisté nálezy byly uváděny pouze z Jižního Kypru (viz Benda et al. 2007), je ze Severního Kypru nyní známa celá kyperská fauna netopýrů. Ovšem tři druhy netopýrů (Rhinolopus mehelyi, Myotis capaccinii, Eptesicus anatolicus) jsou známé jen se severní části Kypru (navíc všechny z jediného nálezu), avšak nález netopýra dlouhonohého (Myotis capaccinii) je považován za problematický a výskyt druhu na ostrově za nepravděpodobný. Poprvé je také možnost konstatování populačního trendu u netopýrů na Kypru; během nedávného výzkumu byly pozorovány mnohem menší počty jedinců (či jejich úplné vymizení) v koloniích kaloně egyptského (Rousettus aegyptiacus) než během výzkumu v prvním desetiletí 21 . století. 


\section{A c know le d gements}

We are grateful to Nursel Așan (Kirikkale), Christian Dodelın (Paris), Giuliano Doria (Genoa), Mustafa Merakli (Lefkoşa), Jiř́ Šmíd (Prague), and Friederike Spitzenberger (Vienna) for their help in the field, for providing data and/or for valuable discussions. The preparation of this review was supported by the Ministry of Culture of the Czech Republic (project DKRVO 2018/14, 00023272) and by the Scientific Grant Agency of the Slovak Republic (projects VEGA 2/0131/17 and 1/0298/19). This research was led by Mağara Meraklıları Derneği (Cave Enthusiasts NGO) in Cyprus and the International Union of Speleology (UIS) in Slovenia. Most of the fieldwork was funded by the European Union as a part of the "Caves of Kyrenia Mountains Project: Research, Conservation, and Education" through the "Cypriot Civil Society in Action V Programme" (contract number: 2015/371-989) and co-financed by the USA Embassy in Nicosia. The content of this contribution is under responsibility of the authors and do not necessarily reflects the view of the European Union.

\section{REFERENCES}

Arslan A., Zima J., Albayrak İ., Yorulmaz T. \& Arslan E., 2015: C-heterochromatin and NORs distribution in karyotypes of three vespertilionid bat species from Turkey. Biologia, Bratislava, 70: 400-405.

Așan Baydemir N., 2014: Bat fauna of Turkey and Northern Cyprus: Species diversity, anthropogenic roosts disturbace and conservation status. Journal of International Environmental Applications and Science, 9: 590-596.

Bate D. M. A., 1903: The Mammals of Cyprus. Proceedings of the Zoological Society of London, 1903(2): 341-348.

Benda P. \& HorÁčeK I., 1998: Bats (Mammalia: Chiroptera) of the Eastern Mediterranean. Part 1. Review of distribution and taxonomy of bats in Turkey. Acta Societatis Zoologicae Bohemicae, 62: 255-313.

Benda P. \& Uhrin M., 2017: First records of bats from four Dodecanese islands, Greece (Chiroptera). Lynx, n. S., 48: 15-38.

Benda P., Andreas M., Kock D., Lučan R. K., Munclinger P., Nová P., Obuch J., Ochman K., Reiter A., Uhrin M. \& Weinfurtová D., 2006: Bats (Mammalia: Chiroptera) of the Eastern Mediterranean. Part 4. Bat fauna of Syria: distribution, systematics, ecology. Acta Societatis Zoologicae Bohemicae, 70: 1-329.

Benda P., Hanák V., Horáček I., Hulva P., Lučan R. \& Ruedi M., 2007: Bats (Mammalia: Chiroptera) of the Eastern Mediterranean. Part 5. Bat fauna of Cyprus: review of records with confirmation of six species new for the island and description of a new subspecies. Acta Societatis Zoologicae Bohemicae, 71: 71-130.

Benda P., Dietz C., Andreas M., Hotový J., Lučan R. K., Maltby A., Meakin K., Truscott J. \& ValLo P., 2008: Bats (Mammalia: Chiroptera) of the Eastern Mediterranean and Middle East. Part 6. Bats of Sinai (Egypt) with some taxonomic, ecological and echolocation data on that fauna. Acta Societatis Zoologicae Bohemicae, 72: 1-103.

Benda P., Georgiakakis P., Dietz C., Hanák V., Galanaki K., Markantonatou V., Chudárková A., HulVA P. \& HorÁČEK I., 2009: Bats (Mammalia: Chiroptera) of the Eastern Mediterranean and Middle East. Part 7. The bat fauna of Crete, Greece. Acta Societatis Zoologicae Bohemicae, 72[2008]: 105-190.

Benda P., Lučan R. K., Obuch J., Reiter A., Andreas M., BačKor P., Bohnenstengel T., Eid E. K., ŠEvČíK M., Vallo P. \& AMr Z. S., 2010: Bats (Mammalia: Chiroptera) of the Eastern Mediterranean and Middle East. Part 8. Bats of Jordan: fauna, ecology, echolocation, ectoparasites. Acta Societatis Zoologicae Bohemicae, 74: 185-353.

Benda P., Abi-Said M., BartoničKa T., Bilgin R., Faizolahi K., Lučan R. K., Nicolaou H., Reiter A., Shohd W. M., Uhrin M. \& HorÁČEK I., 2011: Rousettus aegyptiacus (Pteropodidae) in the Palaearctic: list of records and revision of the distribution range. Vespertilio, 15: 3-36. 
Benda P., Spitzenberger F., HanÁk V., Andreas M., Reiter A., Ševčík M., Šmíd J. \& Uhrin M., 2014: Bats (Mammalia: Chiroptera) of the Eastern Mediterranean and Middle East. Part 11. On the bat fauna of Libya II. Acta Societatis Zoologicae Bohemicae, 78: 1-162.

Benda P., Abi Said M. R., Bou Jaoude I., Karanouh R., Lučan R. K., Sadek R., Ševčíik M., Uhrin M. \& HoRÁČEK I., 2016: Bats (Mammalia: Chiroptera) of the Eastern Mediterranean and Middle East. Part 13. Review of distribution and ectoparasites of bats in Lebanon. Acta Societatis Zoologicae Bohemicae, 80: 207-316.

Bergmans W., 1994: Taxonomy and biogeography of African fruit bats (Mammalia, Megachiroptera). 4. The genus Rousettus Gray, 1821. Beaufortia, 44(4): 79-126.

Boye P., Pott-Dörfer B., Dörfer K. \& Demetropoulos A., 1990: New records of bats (Chiroptera) from Cyprus and notes on their biology. Myotis, 28: 93-100.

Dool S. E., Puechmaille S. J., Dietz C., Juste J., Ibáñez C., Hulva P., Roué S. G., Petit E. J., Jones G., Russo D., Toffoli R., Viglino A., Martinoli A., Rossiter S. J. \& Teeling E. C., 2013: Phylogeography and postglacial recolonization of Europe by Rhinolophus hipposideros: evidence from multiple genetic markers. Molecular Ecology, 22: 4055-4070.

Felten H., Spitzenberger F. \& Storch G., 1977: Zur Kleinsäugerfauna West-Anatoliens. Teil IIIa. Senckenbergiana Biologica, 58: 1-44.

Flanders J., Jones G., Benda P., Dietz C., Zhang S., Li G., Sharifi M. \& Rossiter S. J., 2009: Phylogeography of the greater horseshoe bat, Rhinolophus ferrumequinum: contrasting results from mitochondrial and microsatellite data. Molecular Ecology, 18: 306-318.

Georgiakakis P., Poursanidis D., Kantzaridou M., Kontogeorgos G. \& Russo D., 2018: The importance of forest conservation for the survival of the range-restricted Pipistrellus hanaki, an endemic bat from Crete and Cyrenaica. Mammalian Biology, 93: 109-117.

HADJISTERKotis E., 2006: The destruction and conservation of the Egyptian fruit bat Rousettus aegyptiacus in Cyprus: a historic review. European Journal of Wildlife Research, 52: 282-287.

Harrison D. L., 1964: The Mammals of Arabia. Volume I. Introduction, Insectivora, Chiroptera, Primates. Ernest Benn Limited, London, 192 pp.

Harrison D. L. \& Bates P. J. J., 1991: The Mammals of Arabia. Second Edition. Harrison Zoological Museum, Sevenoaks, $354 \mathrm{pp}$.

von Helversen O., 1998: Eptesicus bottae (Mammalia, Chiroptera) auf der Insel Rhodos. Bonner Zoologische Beiträge, 48: 113-121.

Hulva P., Marešová T., Dundarova H., Bilgin R., Benda P., BartoničKa T. \& Horáček I., 2012: Environmental margin and island evolution in Middle Eastern populations of the Egyptian fruit bat. Molecular Ecology, 21: 6104-6116.

KAHMANN H. \& ÇAĞLAR M., 1959: Türkiyede memeli hayvanlar araştırmı sahasında yeni buluşlar [New data on Turkish mammalian fauna brought by a recent research]. Türk Bioloji Dergisi, 10(3): 119-126 (in Turkish).

KAHMANn H. \& ÇAĞLAR M., 1960: Beitraege zur Saeugetierkunde der Türkei. 1 - Fledermaeuse aus der Landschaft Hatay (Eine vorlaeufige Mitteilung). Istanbul Üniversitesi Fen Fakültesi Mecmuasi, Seri B [Revue de la Faculte des Sciences de l'Universite d'Istanbul, Serie B], 25(1-2): 1-21.

KARATAȘ A. \& ÖZGÜl S. A., 2003: On the occurrence of Geoffroy's bat, Myotis emarginatus (Geoffroy, 1806), in Turkey (Chiroptera: Vespertilionidae). Zoology in the Middle East, 28: 17-24.

Karataș A., Benda P., Toprak F. \& KaraKaya H., 2003: New and significant records of Myotis capaccinii (Chiroptera: Vespertilionidae) from Turkey, with some data on its biology. Lynx, n. s., 34: 39-46.

Kiefer A. \& von Helversen O., 2004: Plecotus kolombatovici (Đulić, 1980) - Balkanlangohr. Pp.: 10591066. In: Krapp F. (ed.): Handbuch der Säugetiere Europas. Band 4: Fledertiere. Teil II: Chiroptera II. Vespertilionidae 2, Molossidae, Nycteridae. Aula-Verlag, Wiebelsheim, x+605-1186 pp.

Kock D., 1974: Pupipare Dipteren von Säugetieren des nordöstlichen Mittelmeerraumes (Ins.: Diptera). Senckenbergiana Biologica, 55: 87-104.

KrYštufek B. \& Vohralí V., 2001: Mammals of Turkey and Cyprus. Introduction, Checklist, Insectivora. Knjižnica Annales Majora. Zgodovinsko društvo za južno Primorsko, Koper, 140 pp. 
Lučan R., BartoničKa T., Benda P., Bilgin R., JedličKa P., Nicolaou H., Reiter A., Shohdi W. M.,

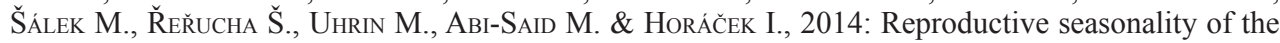
European fruit bat (Rousettus aegyptiacus) at the northern limits of its distribution. Journal of Mammalogy, 95: 1036-1042.

Opstaele P., 1990: Waarneming van species vliegende hond op Cyprus (Bellapais). Nieuwsbrief Vleermuiswerkgroep Nederland, 5: 15-17.

Papadatou E., Butlin R. K. \& Altringham J. D., 2008: Identification of bat species in Greece from their echolocation calls. Acta Chiropterologica, 10: 127-143.

Rossiter S., Benda P., Dietz C., Zhang S. \& Jones G., 2007: Rangewide phylogeography in the greater horseshoe bat inferred from microsatellites: implications for population history, taxonomy and conservation. Molecular Ecology, 16: 4699-4714.

Sachanowicz K. \& Ciechanowski M., 2018: Bats of Albania. Bogucki Wydawnictwo Naukowe, Poznań, $128 \mathrm{pp}$.

ŠEvČík M., BEnda P. \& LuČAn R. K., 2013: Diptera Pupipara from bats of two large eastern Mediterranean islands, Crete and Cyprus. Turkish Journal of Zoology, 37: 31-37.

Spitzenberger F., 1979: Die Säugetierfauna Zyperns. Teil II: Chiroptera, Lagomorpha, Carnivora und Artiodactyla. Annalen des Naturhistorischen Museums in Wien, 82: 439-465.

Spitzenberger F., 1994: The genus Eptesicus (Mammalia, Chiroptera) in Southern Anatolia. Folia Zoologica, 43: 437-454.

Strachinis I., Kalaentzis K., Katsiyiannis P. \& Kazilas C., 2018: First record of the Egyptian fruit bat, Rousettus aegyptiacus (Pteropodidae), from Kastellorizo island, Greece. Mammalia, 82: 611-613.

Theodor O., 1967: An Illustrated Catalogue of the Rothschild Collection of Nycteribiidae (Diptera) in the British Museum (Natural History). Publication 655. Trustees of British Musem (Natural History), London, $506 \mathrm{pp}$.

Tvrtković N., Pavlinić I. \& Haring E., 2005: Four species of long-eared bats (Plecotus, Geoffroy, 1818; Mammalia, Vespertilionidae) in Croatia: field identification and distribution. Folia Zoologica, 54: 75-88.

YiĞIT N., Bulut Ş., Karataș A., ÇAM P. \& SAYGiLi F., 2008: Contribution to the distribution, morphological peculiarities and karyology of the greater noctule, Nyctalus lasiopterus (Chiroptera: Vespertilionidae), in Southwestern Turkey. Turkish Journal of Zoology, 32: 53-58. 


\begin{tabular}{|c|c|c|}
\hline \multirow{2}{*}{$\frac{\text { site name }}{\text { Afendrika }[A \varphi \varepsilon ́ v \tau \rho \iota \kappa \alpha], \text { Asomatos church }}$} & \multicolumn{2}{|c|}{ coordinates altitude } \\
\hline & $35^{\circ} 38^{\prime} 50^{\prime \prime} \mathrm{N}, 34^{\circ} 26^{\prime} 28^{\prime \prime} \mathrm{E}$ & $26 \mathrm{~m}$ \\
\hline 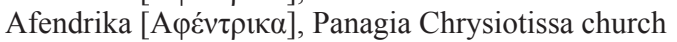 & $35^{\circ} 38^{\prime} 53^{\prime \prime} \mathrm{N}, 34^{\circ} 26^{\prime} 27^{\prime \prime} \mathrm{E}$ & $22 \mathrm{~m}$ \\
\hline 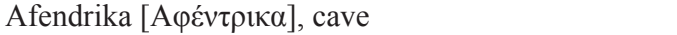 & $35^{\circ} 38^{\prime} 48^{\prime \prime} \mathrm{N}, 34^{\circ} 26^{\prime} 36^{\prime \prime} \mathrm{E}$ & $38 \mathrm{~m}$ \\
\hline 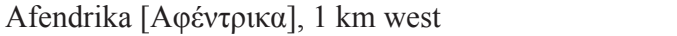 & $35^{\circ} 38^{\prime} 43^{\prime \prime} \mathrm{N}, 34^{\circ} 25^{\prime} 55^{\prime \prime} \mathrm{E}$ & $20 \mathrm{~m}$ \\
\hline 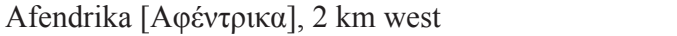 & $35^{\circ} 38^{\prime} 38^{\prime \prime} \mathrm{N}, 34^{\circ} 25^{\prime} 37^{\prime \prime} \mathrm{E}$ & $26 \mathrm{~m}$ \\
\hline 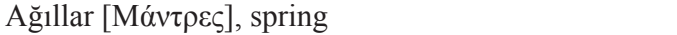 & $35^{\circ} 20^{\prime} 48^{\prime \prime} \mathrm{N}, 33^{\circ} 48^{\prime} 37^{\prime \prime} \mathrm{E}$ & $266 \mathrm{~m}$ \\
\hline 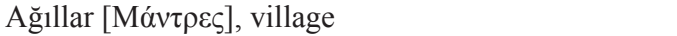 & $35^{\circ} 20^{\prime} 59^{\prime \prime} \mathrm{N}, 33^{\circ} 47^{\prime} 55^{\prime \prime} \mathrm{E}$ & $334 \mathrm{~m}$ \\
\hline 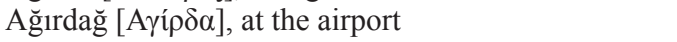 & $35^{\circ} 16^{\prime} 46^{\prime \prime} \mathrm{N}, 33^{\circ} 16^{\prime} 13^{\prime \prime} \mathrm{E}$ & $242 \mathrm{~m}$ \\
\hline Ağırdağ [A $\gamma i ́ \rho \delta \alpha]$, cleft cave \& cliff & $35^{\circ} 17^{\prime} 58^{\prime \prime} \mathrm{N}, 33^{\circ} 15^{\prime} 19^{\prime \prime} \mathrm{E}$ & $540 \mathrm{~m}$ \\
\hline 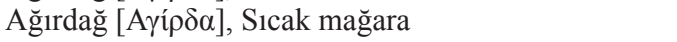 & $35^{\circ} 18^{\prime} 09^{\prime \prime} \mathrm{N}, 33^{\circ} 16^{\prime} 12^{\prime \prime} \mathrm{E}$ & $585 \mathrm{~m}$ \\
\hline 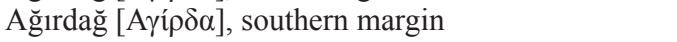 & $35^{\circ} 15^{\prime} 26^{\prime \prime} \mathrm{N}, 33^{\circ} 17^{\prime} 07^{\prime \prime} \mathrm{E}$ & $219 \mathrm{~m}$ \\
\hline \multicolumn{3}{|l|}{ 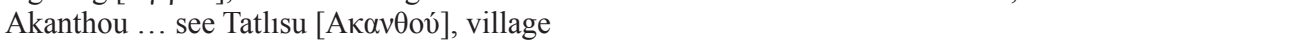 } \\
\hline 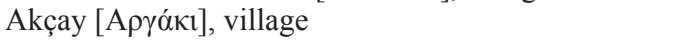 & $35^{\circ} 10^{\prime} 40^{\prime \prime} \mathrm{N}, 33^{\circ} 02^{\prime} 04^{\prime \prime} \mathrm{E}$ & $98 \mathrm{~m}$ \\
\hline 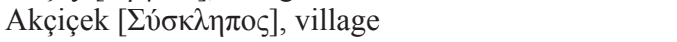 & $35^{\circ} 17^{\prime} 58^{\prime \prime} \mathrm{N}, 33^{\circ} 10^{\prime} 22^{\prime \prime} \mathrm{E}$ & $370 \mathrm{~m}$ \\
\hline 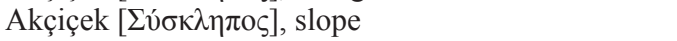 & $35^{\circ} 18^{\prime} 10^{\prime \prime} \mathrm{N}, 33^{\circ} 10^{\prime} 22^{\prime \prime} \mathrm{E}$ & $419 \mathrm{~m}$ \\
\hline Akdoğan $[\Lambda v ́ \sigma \eta]$, eastern part & $35^{\circ} 06^{\prime} 19^{\prime \prime} \mathrm{N}, 33^{\circ} 41^{\prime} 24^{\prime \prime} \mathrm{E}$ & $52 \mathrm{~m}$ \\
\hline 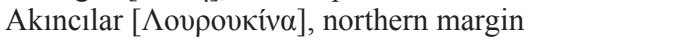 & $35^{\circ} 01^{\prime} 11^{\prime \prime} \mathrm{N}, 33^{\circ} 27^{\prime} 57^{\prime \prime} \mathrm{E}$ & $216 \mathrm{~m}$ \\
\hline 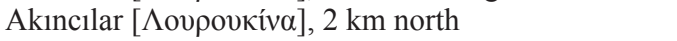 & $35^{\circ} 02^{\prime} 11^{\prime \prime} \mathrm{N}, 33^{\circ} 28^{\prime} 36^{\prime \prime} \mathrm{E}$ & $185 \mathrm{~m}$ \\
\hline 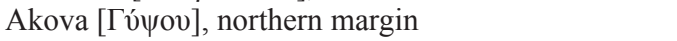 & $35^{\circ} 15^{\prime} 45^{\prime \prime} \mathrm{N}, 33^{\circ} 47^{\prime} 03^{\prime \prime} \mathrm{E}$ & $62 \mathrm{~m}$ \\
\hline Akova [Гú & $35^{\circ} 15^{\prime} 41^{\prime \prime} \mathrm{N}, 33^{\circ} 46^{\prime} 09^{\prime \prime} \mathrm{E}$ & $63 \mathrm{~m}$ \\
\hline 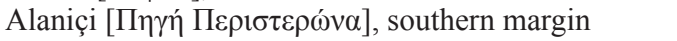 & $35^{\circ} 12^{\prime} 30^{\prime \prime} \mathrm{N}, 33^{\circ} 45^{\prime} 24^{\prime \prime} \mathrm{E}$ & $25 \mathrm{~m}$ \\
\hline 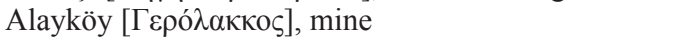 & $35^{\circ} 10^{\prime} 18^{\prime \prime} \mathrm{N}, 33^{\circ} 15^{\prime} 19^{\prime \prime} \mathrm{E}$ & $202 \mathrm{~m}$ \\
\hline 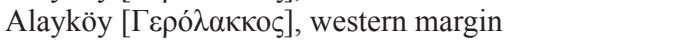 & $35^{\circ} 11^{\prime} 32^{\prime \prime} \mathrm{N}, 33^{\circ} 14^{\prime} 31^{\prime \prime} \mathrm{E}$ & $165 \mathrm{~m}$ \\
\hline 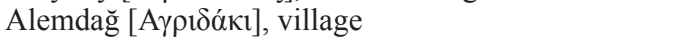 & $35^{\circ} 18^{\prime} 28^{\prime \prime} \mathrm{N}, 33^{\circ} 09^{\prime} 05^{\prime \prime} \mathrm{E}$ & $435 \mathrm{~m}$ \\
\hline Alevkaya $[\mathrm{X} \alpha \lambda \varepsilon v \kappa \alpha]$, Alevkaya kanyon & $35^{\circ} 17^{\prime} 23^{\prime \prime} \mathrm{N}, 33^{\circ} 31^{\prime} 53^{\prime \prime} \mathrm{E}$ & $662 \mathrm{~m}$ \\
\hline Alevkaya [X $\alpha \lambda \varepsilon v \kappa \alpha]$, Alevkaya yol kenarı & $35^{\circ} 17^{\prime} 01^{\prime \prime} \mathrm{N}, 33^{\circ} 31^{\prime} 26^{\prime \prime} \mathrm{E}$ & $646 \mathrm{~m}$ \\
\hline Alevkaya $[\mathrm{X} \alpha \lambda \varepsilon v \kappa \alpha]$, crossing of roads & $35^{\circ} 17^{\prime} 11^{\prime \prime} \mathrm{N}, 33^{\circ} 31^{\prime} 51^{\prime \prime} \mathrm{E}$ & $640 \mathrm{~m}$ \\
\hline Alevkaya $[\mathrm{X} \alpha \lambda \varepsilon v \kappa \alpha]$, Girne Kayasi & $35^{\circ} 17^{\prime} 21^{\prime \prime} \mathrm{N}, 33^{\circ} 30^{\prime} 33^{\prime \prime} \mathrm{E}$ & $631 \mathrm{~m}$ \\
\hline Alevkaya $[X \alpha \lambda \varepsilon v \kappa \alpha]$, Küpo mağarası & $35^{\circ} 17^{\prime} 07^{\prime \prime} \mathrm{N}, 33^{\circ} 32^{\prime} 27^{\prime \prime} \mathrm{E}$ & $702 \mathrm{~m}$ \\
\hline Alevkaya $[X \alpha \lambda \varepsilon v \kappa \alpha]$, Saray mağarası & $35^{\circ} 16^{\prime} 56^{\prime \prime} \mathrm{N}, 33^{\circ} 32^{\prime} 09^{\prime \prime} \mathrm{E}$ & $512 \mathrm{~m}$ \\
\hline Alsancak [K $\alpha \rho \alpha \beta \alpha ́ s]$, village & $35^{\circ} 20^{\prime} 52^{\prime \prime} \mathrm{N}, 33^{\circ} 11^{\prime} 54^{\prime \prime} \mathrm{E}$ & 291 \\
\hline 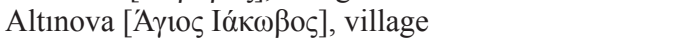 & $35^{\circ} 19^{\prime} 36^{\prime \prime} \mathrm{N}, 33^{\circ} 48^{\prime} 59^{\prime \prime} \mathrm{E}$ & $164 \mathrm{~m}$ \\
\hline 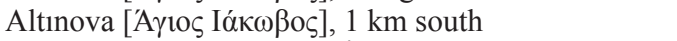 & $35^{\circ} 19^{\prime} 10^{\prime \prime} \mathrm{N}, 33^{\circ} 49^{\prime} 17^{\prime \prime} \mathrm{E}$ & $149 \mathrm{~m}$ \\
\hline 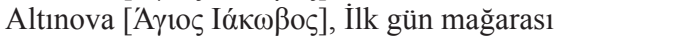 & $35^{\circ} 19^{\prime} 19^{\prime \prime} \mathrm{N}, 33^{\circ} 47^{\prime} 36^{\prime \prime} \mathrm{E}$ & $271 \mathrm{~m}$ \\
\hline 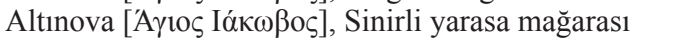 & $35^{\circ} 19^{\prime} 22^{\prime \prime} \mathrm{N}, 33^{\circ} 47^{\prime} 51^{\prime \prime} \mathrm{E}$ & $335 \mathrm{~m}$ \\
\hline 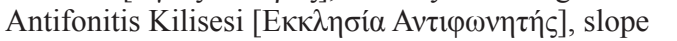 & $35^{\circ} 19^{\prime} 38^{\prime \prime} \mathrm{N}, 33^{\circ} 37^{\prime} 10^{\prime \prime} \mathrm{E}$ & $362 \mathrm{~m}$ \\
\hline Apostolos Andreas manastır1 [A & $35^{\circ} 39^{\prime} 32^{\prime \prime} \mathrm{N}, 34^{\circ} 34^{\prime} 19^{\prime \prime} \mathrm{E}$ & 241 \\
\hline 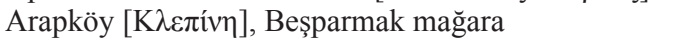 & $35^{\circ} 16^{\prime} 58^{\prime \prime} \mathrm{N}, 33^{\circ} 28^{\prime} 36^{\prime \prime} \mathrm{E}$ & $603 \mathrm{~m}$ \\
\hline 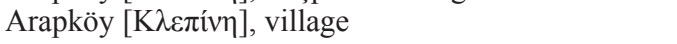 & $35^{\circ} 18^{\prime} 38^{\prime \prime} \mathrm{N}, 33^{\circ} 25^{\prime} 39^{\prime \prime} \mathrm{E}$ & $185 \mathrm{~m}$ \\
\hline Arapköy $[\mathrm{K} \lambda \varepsilon \pi i v \eta]$, north & $35^{\circ} 19^{\prime} 01^{\prime \prime} \mathrm{N}, 33^{\circ} 25^{\prime} 29^{\prime \prime} \mathrm{E}$ & $122 \mathrm{~m}$ \\
\hline Ardahan [A $\rho \delta \alpha v \alpha]$, southern margin & $35^{\circ} 21^{\prime} 12^{\prime \prime} \mathrm{N}, 33^{\circ} 53^{\prime} 23^{\prime \prime} \mathrm{E}$ & $193 \mathrm{~m}$ \\
\hline 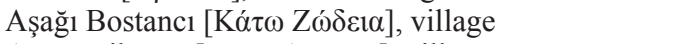 & $35^{\circ} 09^{\prime} 53^{\prime \prime} \mathrm{N}, 33^{\circ} 00^{\prime} 30^{\prime \prime} \mathrm{E}$ & $93 \mathrm{~m}$ \\
\hline 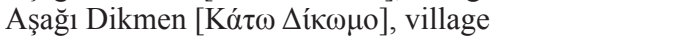 & $35^{\circ} 15^{\prime} 58^{\prime \prime} \mathrm{N}, 33^{\circ} 19^{\prime} 46^{\prime \prime} \mathrm{E}$ & $225 \mathrm{~m}$ \\
\hline Aslanköy [A $\gamma \gamma \alpha \sigma \tau i v \alpha]$, crossing $3 \mathrm{~km}$ east & $35^{\circ} 11^{\prime} 46^{\prime \prime} \mathrm{N}, 33^{\circ} 37^{\prime} 03^{\prime \prime} \mathrm{E}$ & $56 \mathrm{~m}$ \\
\hline 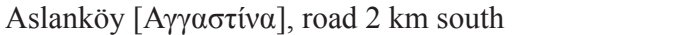 & $35^{\circ} 10^{\prime} 53^{\prime \prime} \mathrm{N}, 33^{\circ} 35^{\prime} 47^{\prime \prime} \mathrm{E}$ & $59 \mathrm{~m}$ \\
\hline Avtepe $[$ A $\gamma 10 \varsigma \Sigma v \mu \varepsilon \omega \dot{\omega}$ ], village & $35^{\circ} 29^{\prime} 25^{\prime \prime} \mathrm{N}, 34^{\circ} 13^{\prime} 07^{\prime \prime} \mathrm{E}$ & $187 \mathrm{~m}$ \\
\hline 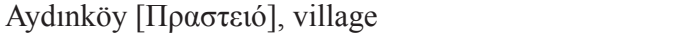 & $35^{\circ} 10^{\prime} 45^{\prime \prime} \mathrm{N}, 32^{\circ} 56^{\prime} 33^{\prime \prime} \mathrm{E}$ & $22 \mathrm{~m}$ \\
\hline
\end{tabular}




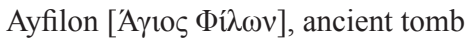

Ayfilon ['A $\gamma 10 \varsigma \Phi i ́ \lambda \omega v]$, basilica ruins

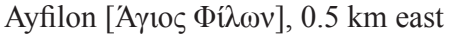

Ayfilon ['A $\gamma 10 \varsigma$ $\Phi$ í $\lambda \omega v], 1 \mathrm{~km}$ south-south-east

Ayfilon [A'Aroc $\Phi \dot{\lambda} \lambda \omega v], 1 \mathrm{~km}$ south-west

Ayfilon ['A $\gamma 10 \varsigma$ $\Phi \dot{i} \lambda \omega v]$, Roman harbor

Ayfilon ['A $\gamma 10 \varsigma$ $\Phi i ́ \lambda \omega v]$, Roman harbor, $1 \mathrm{~km}$ east

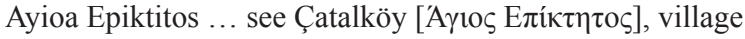

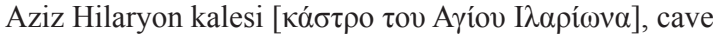

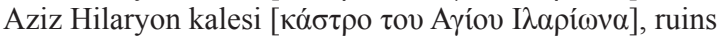

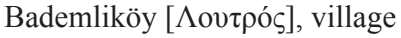

Bafra [Вокодís $\alpha]$, village

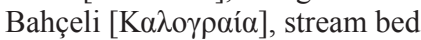

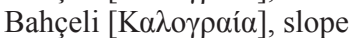

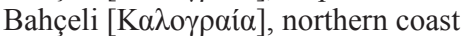

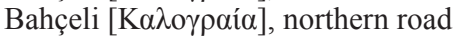

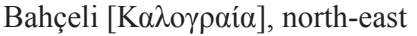

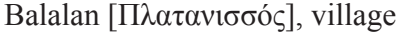

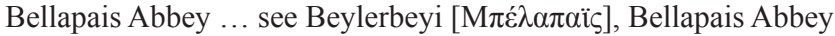

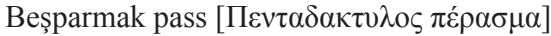

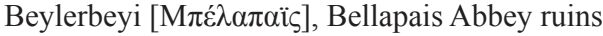

Beylerbeyi [M $\pi \dot{\lambda} \lambda \alpha \pi \alpha i ̈ \varsigma]$, village

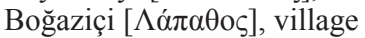

Boğazköy [M $\left[\mathrm{o} о \gamma_{\alpha} \zeta_{\zeta}\right]$, village

Boğaztepe [Móv $\alpha \rho \gamma \alpha]$, village

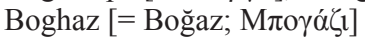

Boltaşl1 [ $\Lambda v \theta \rho \alpha ́ \gamma \kappa \omega \mu \eta]$, village

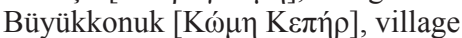

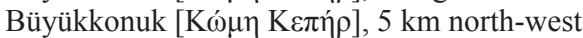

Çamlıca [Гov́ $\varphi \varepsilon \varsigma]$, village

Çamlıca [Гoú $\varphi \varepsilon \varsigma], 1 \mathrm{~km}$ south

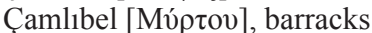

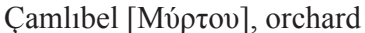

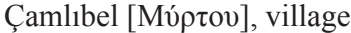

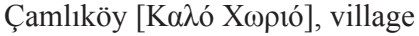

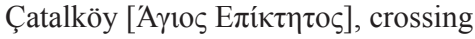

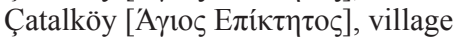

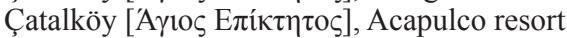

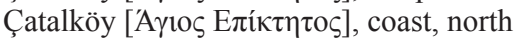

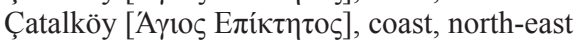

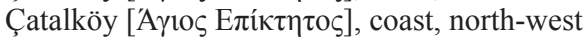

Çayönü $\left[K \alpha \lambda \circ \psi \psi^{\prime} \delta \alpha\right]$, eastern margin

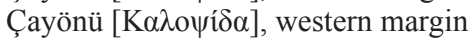

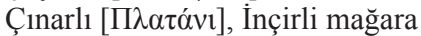

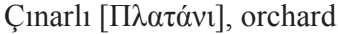

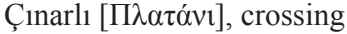

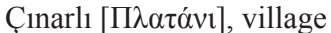

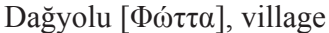

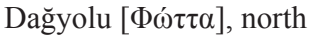

$35^{\circ} 37^{\prime} 23^{\prime \prime} \mathrm{N}, 34^{\circ} 21^{\prime} 57^{\prime \prime} \mathrm{E} \quad 26 \mathrm{~m}$

$35^{\circ} 37^{\prime} 48^{\prime \prime} \mathrm{N}, 34^{\circ} 22^{\prime} 26^{\prime \prime} \mathrm{E} \quad 6 \mathrm{~m}$

$35^{\circ} 37^{\prime} 51^{\prime \prime} \mathrm{N}, 34^{\circ} 22^{\prime} 41^{\prime \prime} \mathrm{E} \quad 9 \mathrm{~m}$

$35^{\circ} 37^{\prime} 10^{\prime \prime} \mathrm{N}, 34^{\circ} 22^{\prime} 39^{\prime \prime} \mathrm{E} \quad 78 \mathrm{~m}$

$35^{\circ} 37^{\prime} 30^{\prime \prime} \mathrm{N}, 34^{\circ} 21^{\prime} 59^{\prime \prime} \mathrm{E} \quad 5 \mathrm{~m}$

$35^{\circ} 38^{\prime} 05^{\prime \prime} \mathrm{N}, 34^{\circ} 23^{\prime} 27^{\prime \prime} \mathrm{E} \quad 5 \mathrm{~m}$

$35^{\circ} 38^{\prime} 09^{\prime \prime} \mathrm{N}, 34^{\circ} 24^{\prime} 48^{\prime \prime} \mathrm{E} \quad 24 \mathrm{~m}$

$35^{\circ} 18^{\prime} 47^{\prime \prime} \mathrm{N}, 33^{\circ} 17^{\prime} 02^{\prime \prime} \mathrm{E} \quad 493 \mathrm{~m}$

$35^{\circ} 18^{\prime} 44$ " N, $33^{\circ} 16^{\prime} 53^{\prime \prime}$ E $635 \mathrm{~m}$

$35^{\circ} 09^{\prime} 34^{\prime \prime} \mathrm{N}, 32^{\circ} 45^{\prime} 46^{\prime \prime} \mathrm{E} 179 \mathrm{~m}$

$35^{\circ} 22^{\prime} 48^{\prime \prime} \mathrm{N}, 34^{\circ} 04^{\prime} 25^{\prime \prime} \mathrm{E} \quad 12 \mathrm{~m}$

$35^{\circ} 21$ ' 14 " N, $33^{\circ} 38^{\prime} 52^{\prime \prime} \mathrm{E} \quad 43 \mathrm{~m}$

$35^{\circ} 20^{\prime} 10^{\prime \prime} \mathrm{N}, 33^{\circ} 38^{\prime} 02^{\prime \prime} \mathrm{E} 218 \mathrm{~m}$

$35^{\circ} 21^{\prime} 30^{\prime \prime} \mathrm{N}, 33^{\circ} 38^{\prime} 09^{\prime \prime} \mathrm{E} \quad 6 \mathrm{~m}$

$35^{\circ} 21^{\prime} 08^{\prime \prime} \mathrm{N}, 33^{\circ} 37^{\prime} 40^{\prime \prime} \mathrm{E} \quad 38 \mathrm{~m}$

$35^{\circ} 21^{\prime} 41^{\prime \prime} \mathrm{N}, 33^{\circ} 39^{\prime} 55^{\prime \prime} \mathrm{E} \quad 24 \mathrm{~m}$

$35^{\circ} 28^{\prime} 49^{\prime \prime} \mathrm{N}, 34^{\circ} 06^{\prime} 28^{\prime \prime} \mathrm{E} 127 \mathrm{~m}$

$35^{\circ} 16^{\prime} 50^{\prime \prime} \mathrm{N}, 33^{\circ} 28^{\prime} 01^{\prime \prime} \mathrm{E} 502 \mathrm{~m}$

$35^{\circ} 18^{\prime} 26^{\prime \prime} \mathrm{N}, 33^{\circ} 21^{\prime} 20^{\prime \prime} \mathrm{E} \quad 213 \mathrm{~m}$

$35^{\circ} 18^{\prime} 18^{\prime \prime} \mathrm{N}, 33^{\circ} 21^{\prime} 18^{\prime \prime}$ E $250 \mathrm{~m}$

$35^{\circ} 16^{\prime} 18^{\prime \prime} \mathrm{N}, 33^{\circ} 49^{\prime} 37^{\prime \prime} \mathrm{E} \quad 46 \mathrm{~m}$

$35^{\circ} 17^{\prime} 26^{\prime \prime} \mathrm{N}, 33^{\circ} 16^{\prime} 55^{\prime \prime} \mathrm{E} 262 \mathrm{~m}$

$35^{\circ} 19^{\prime} 02^{\prime \prime} \mathrm{N}, 33^{\circ} 56^{\prime} 30^{\prime \prime} \mathrm{E} \quad 43 \mathrm{~m}$

$35^{\circ} 18^{\prime} 52^{\prime \prime} \mathrm{N}, 33^{\circ} 57^{\prime} 10^{\prime \prime} \mathrm{E} \quad 8 \mathrm{~m}$

$35^{\circ} 28^{\prime} 42^{\prime \prime} \mathrm{N}, 34^{\circ} 09^{\prime} 56^{\prime \prime} \mathrm{E} \quad 149 \mathrm{~m}$

$35^{\circ} 24^{\prime} 32^{\prime \prime} \mathrm{N}, 33^{\circ} 59^{\prime} 51^{\prime \prime} \mathrm{E} \quad 83 \mathrm{~m}$

$35^{\circ} 26^{\prime} 30^{\prime \prime} \mathrm{N}, 33^{\circ} 57^{\prime} 49^{\prime \prime} \mathrm{E} \quad 20 \mathrm{~m}$

$35^{\circ} 16^{\prime} 55^{\prime \prime} \mathrm{N}, 33^{\circ} 41^{\prime} 15^{\prime \prime} \mathrm{E} \quad 93 \mathrm{~m}$

$35^{\circ} 16^{\prime} 17^{\prime \prime} \mathrm{N}, 33^{\circ} 41^{\prime} 16^{\prime \prime} \mathrm{E} \quad 75 \mathrm{~m}$

$35^{\circ} 19^{\prime} 44^{\prime \prime} \mathrm{N}, 33^{\circ} 02^{\prime} 19^{\prime \prime} \mathrm{E} 225 \mathrm{~m}$

$35^{\circ} 19^{\prime} 14$ " N, $33^{\circ} 03^{\prime}$ 09” E $227 \mathrm{~m}$

$35^{\circ} 18$ ' $30^{\prime \prime} \mathrm{N}, 33^{\circ} 04^{\prime} 33^{\prime \prime}$ E $263 \mathrm{~m}$

$35^{\circ} 06^{\prime} 45^{\prime \prime} \mathrm{N}, 32^{\circ} 52^{\prime} 27^{\prime \prime} \mathrm{E} 134 \mathrm{~m}$

$35^{\circ} 19^{\prime} 44^{\prime \prime} \mathrm{N}, 33^{\circ} 25^{\prime} 00^{\prime \prime} \mathrm{E} \quad 37 \mathrm{~m}$

$35^{\circ} 19^{\prime} 37^{\prime \prime} \mathrm{N}, 33^{\circ} 23^{\prime} 33^{\prime \prime} \mathrm{E} \quad 38 \mathrm{~m}$

$35^{\circ} 19^{\prime} 46^{\prime \prime} \mathrm{N}, 33^{\circ} 25^{\prime} 32^{\prime \prime} \mathrm{E} \quad 29 \mathrm{~m}$

$35^{\circ} 19^{\prime} 54^{\prime \prime} \mathrm{N}, 33^{\circ} 23^{\prime} 51^{\prime \prime} \mathrm{E} \quad 17 \mathrm{~m}$

$35^{\circ} 19^{\prime} 39^{\prime \prime} \mathrm{N}, 33^{\circ} 24^{\prime} 34^{\prime \prime} \mathrm{E} \quad 33 \mathrm{~m}$

$35^{\circ} 19^{\prime} 59^{\prime \prime} \mathrm{N}, 33^{\circ} 22^{\prime} 38^{\prime \prime} \mathrm{E} \quad 19 \mathrm{~m}$

$35^{\circ} 05^{\prime} 50^{\prime \prime} \mathrm{N}, 33^{\circ} 47^{\prime} 52^{\prime \prime} \mathrm{E} \quad 18 \mathrm{~m}$

$35^{\circ} 06^{\prime} 09^{\prime \prime} \mathrm{N}, 33^{\circ} 46^{\prime} 43^{\prime \prime} \mathrm{E} \quad 26 \mathrm{~m}$

$35^{\circ} 19^{\prime} 30^{\prime \prime} \mathrm{N}, 33^{\circ} 46^{\prime} 11^{\prime \prime} \mathrm{E} 246 \mathrm{~m}$

$35^{\circ} 19^{\prime} 42^{\prime \prime} \mathrm{N}, 33^{\circ} 46^{\prime} 18^{\prime \prime} \mathrm{E} \quad 220 \mathrm{~m}$

$35^{\circ} 20^{\prime} 18^{\prime \prime} \mathrm{N}, 33^{\circ} 42^{\prime} 54^{\prime \prime}$ E $264 \mathrm{~m}$

$35^{\circ} 20^{\prime} 02^{\prime \prime} \mathrm{N}, 33^{\circ} 45^{\prime} 07^{\prime \prime} \mathrm{E} 257 \mathrm{~m}$

$35^{\circ} 15^{\prime} 54^{\prime \prime} \mathrm{N}, 33^{\circ} 13^{\prime} 21^{\prime \prime}$ E $252 \mathrm{~m}$

$35^{\circ} 16^{\prime} 21^{\prime \prime} \mathrm{N}, 33^{\circ} 13^{\prime} 30^{\prime \prime}$ E $275 \mathrm{~m}$ 


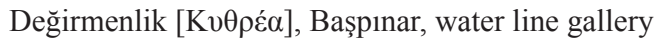

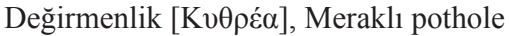

Derince [B $\alpha \theta \dot{\lambda} \lambda \alpha \kappa \alpha \varsigma]$, village

Dilekkaya [Aүió], village

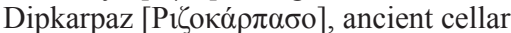

Dipkarpaz [Рı ока́ $\rho \pi \alpha \sigma o]$, village

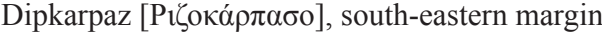

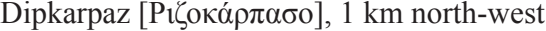

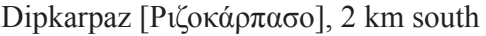

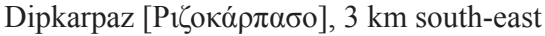

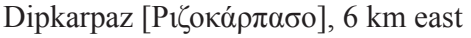

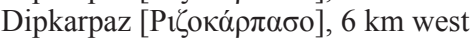

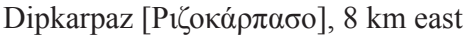

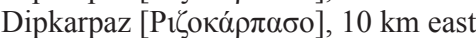

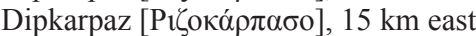

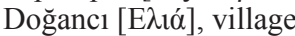

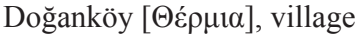

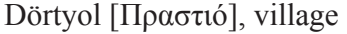

Ercan Havalimanı, $2 \mathrm{~km}$ east

Ercan Havalimanı, $5 \mathrm{~km}$ east

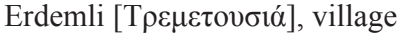

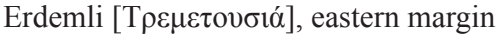

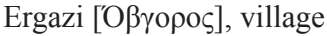

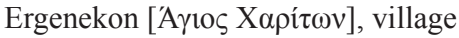

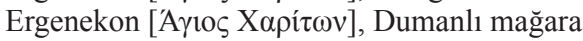

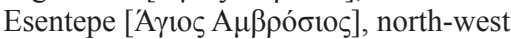

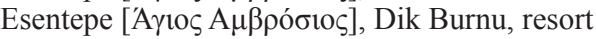

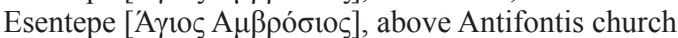

Esentepe [A' $\gamma 10 \varsigma$ A $\mu \beta \rho o ́ \sigma 10 \varsigma]$, slope

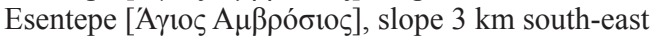

Famagusta [= Gazimağusa] ... see Gazimağusa [A $\mu \mu$ ó $\chi \omega \sigma \tau o \varsigma]$, old town

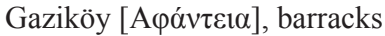

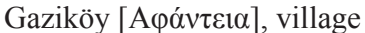

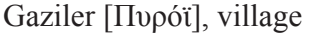

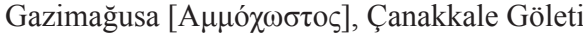

Gazimağusa [A $\mu \mu$ ó $\chi \omega \sigma \tau \varsigma$ ], Baykal, west

Gazimağusa [A $\mu \mu o ́ \chi \omega \sigma \tau o \varsigma]$, Sakarya, west

Gazimağusa [A $\mu \mu$ ó $\chi \omega \sigma \tau o \varsigma]$, old town

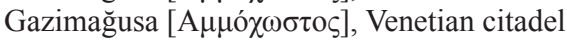

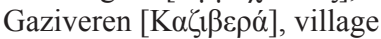

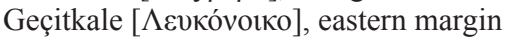

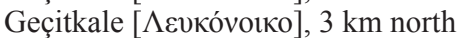

Geçitköy [Пóv $\alpha \gamma \rho \alpha]$, village

Geçitköy [Пóv $\alpha \gamma \rho \alpha], 2$ km north

Gelincik [B $\alpha \sigma i ́ \lambda 1]$, village

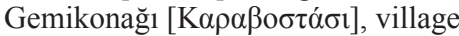

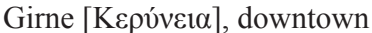

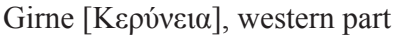

Göçeri [Пı $\lambda \varepsilon ́ p \iota]$, village $35^{\circ} 16^{\prime} 04^{\prime \prime} \mathrm{N}, 33^{\circ} 29^{\prime} 23^{\prime \prime}$ E $276 \mathrm{~m}$

$35^{\circ} 16^{\prime} 36^{\prime \prime} \mathrm{N}, 33^{\circ} 30^{\prime} 49^{\prime \prime} \mathrm{E} 721 \mathrm{~m}$

$35^{\circ} 28^{\prime} 58^{\prime \prime} \mathrm{N}, 34^{\circ} 11^{\prime} 21^{\prime \prime} \mathrm{E} 169 \mathrm{~m}$

$35^{\circ} 06^{\prime} 39^{\prime \prime} \mathrm{N}, 33^{\circ} 33^{\prime} 56^{\prime \prime} \mathrm{E} \quad 97 \mathrm{~m}$

$35^{\circ} 35^{\prime} 11^{\prime \prime} \mathrm{N}, 34^{\circ} 23^{\prime} 46^{\prime \prime} \mathrm{E} 125 \mathrm{~m}$

$35^{\circ} 35^{\prime} 55^{\prime \prime} \mathrm{N}, 34^{\circ} 22^{\prime}, 50^{\prime \prime} \mathrm{E} \quad 140 \mathrm{~m}$

$35^{\circ} 35^{\prime} 23^{\prime \prime} \mathrm{N}, 34^{\circ} 23^{\prime} 31^{\prime \prime}$ E $150 \mathrm{~m}$

$35^{\circ} 35^{\prime} 53^{\prime \prime} \mathrm{N}, 34^{\circ} 20^{\prime} 33^{\prime \prime} \mathrm{E} \quad 31 \mathrm{~m}$

$35^{\circ} 34^{\prime} 35^{\prime \prime} \mathrm{N}, 34^{\circ} 23^{\prime} 11^{\prime \prime} \mathrm{E} \quad 101 \mathrm{~m}$

$35^{\circ} 34^{\prime} 52^{\prime \prime} \mathrm{N}, 34^{\circ} 24^{\prime} 48^{\prime \prime} \mathrm{E} \quad 25 \mathrm{~m}$

$35^{\circ} 35^{\prime} 57^{\prime \prime} \mathrm{N}, 34^{\circ} 25^{\prime} 59^{\prime \prime} \mathrm{E} \quad 17 \mathrm{~m}$

$35^{\circ} 34^{\prime} 36^{\prime \prime} \mathrm{N}, 34^{\circ} 18^{\prime} 04^{\prime \prime} \mathrm{E} \quad 36 \mathrm{~m}$

$35^{\circ} 36^{\prime} 42^{\prime \prime} \mathrm{N}, 34^{\circ} 26^{\prime} 57^{\prime \prime} \mathrm{E} \quad 12 \mathrm{~m}$

$35^{\circ} 37^{\prime} 08^{\prime \prime} \mathrm{N}, 34^{\circ} 28^{\prime} 06^{\prime \prime} \mathrm{E} \quad 15 \mathrm{~m}$

$35^{\circ} 38^{\prime} 08^{\prime \prime} \mathrm{N}, 34^{\circ} 30^{\prime} 33^{\prime \prime} \mathrm{E} \quad 15 \mathrm{~m}$

$35^{\circ} 07^{\prime} 57^{\prime \prime} \mathrm{N}, 32^{\circ} 54^{\prime}$ ' $41^{\prime \prime} \mathrm{E} \quad 102 \mathrm{~m}$

$35^{\circ} 19^{\prime} 38^{\prime \prime} \mathrm{N}, 33^{\circ} 20^{\prime} 18^{\prime \prime} \mathrm{E} \quad 34 \mathrm{~m}$

$35^{\circ} 10^{\prime} 03^{\prime \prime} \mathrm{N}, 33^{\circ} 45^{\prime} 23^{\prime \prime} \mathrm{E} \quad 21 \mathrm{~m}$

$35^{\circ} 09^{\prime} 12^{\prime \prime} \mathrm{N}, 33^{\circ} 31^{\prime} 14^{\prime \prime} \mathrm{E} \quad 97 \mathrm{~m}$

$35^{\circ} 09^{\prime} 21^{\prime \prime} \mathrm{N}, 33^{\circ} 33^{\prime} 20^{\prime \prime} \mathrm{E} \quad 83 \mathrm{~m}$

$35^{\circ} 05^{\prime} 02^{\prime \prime} \mathrm{N}, 33^{\circ} 36^{\prime} 28^{\prime \prime} \mathrm{E} 103 \mathrm{~m}$

$35^{\circ} 05^{\prime} 10^{\prime \prime} \mathrm{N}, 33^{\circ} 36^{\prime} 58^{\prime \prime} \mathrm{E} \quad 99 \mathrm{~m}$

$35^{\circ} 21^{\prime} 58^{\prime \prime} \mathrm{N}, 33^{\circ} 56^{\prime} 14$ ' E $112 \mathrm{~m}$

$35^{\circ} 18^{\prime} 19^{\prime \prime} \mathrm{N}, 33^{\circ} 36^{\prime} 16^{\prime \prime} \mathrm{E} 324 \mathrm{~m}$

$35^{\circ} 18^{\prime} 43^{\prime \prime} \mathrm{N}, 33^{\circ} 35^{\prime} 33^{\prime \prime}$ E $793 \mathrm{~m}$

$35^{\circ} 20^{\prime} 45^{\prime \prime} \mathrm{N}, 33^{\circ} 34^{\prime} 04^{\prime \prime} \mathrm{E} \quad 23 \mathrm{~m}$

$35^{\circ} 21^{\prime} 12^{\prime \prime} \mathrm{N}, 33^{\circ} 36^{\prime} 07^{\prime \prime} \mathrm{E} \quad 38 \mathrm{~m}$

$35^{\circ} 19^{\prime} 29^{\prime \prime} \mathrm{N}, 33^{\circ} 37^{\prime} 01$ ' E $422 \mathrm{~m}$

$35^{\circ} 19^{\prime} 06^{\prime \prime} \mathrm{N}, 33^{\circ} 35^{\prime} 11^{\prime \prime} \mathrm{E} \quad 438 \mathrm{~m}$

$35^{\circ} 19^{\prime} 31^{\prime \prime} \mathrm{N}, 33^{\circ} 36^{\prime} 39^{\prime \prime} \mathrm{E} \quad 406 \mathrm{~m}$

$35^{\circ} 09^{\prime} 24^{\prime \prime} \mathrm{N}, 33^{\circ} 34^{\prime} 13^{\prime \prime} \mathrm{E} \quad 77 \mathrm{~m}$ $35^{\circ} 09^{\prime} 29^{\prime \prime} \mathrm{N}, 33^{\circ} 34^{\prime} 56^{\prime \prime} \mathrm{E} \quad 73 \mathrm{~m}$ $35^{\circ} 04^{\prime} 44^{\prime \prime} \mathrm{N}, 33^{\circ} 29^{\prime} 26^{\prime \prime} \mathrm{E} 159 \mathrm{~m}$ $35^{\circ} 07^{\prime} 23^{\prime \prime} \mathrm{N}, 33^{\circ} 54^{\prime} 36^{\prime \prime} \mathrm{E} \quad 5 \mathrm{~m}$ $35^{\circ} 07^{\prime} 19^{\prime \prime} \mathrm{N}, 33^{\circ} 55^{\prime} 06^{\prime \prime} \mathrm{E} \quad 11 \mathrm{~m}$ $35^{\circ} 08^{\prime} 19^{\prime \prime} \mathrm{N}, 33^{\circ} 54^{\prime} 39^{\prime \prime} \mathrm{E} \quad 7 \mathrm{~m}$ $35^{\circ} 07^{\prime} 30^{\prime \prime} \mathrm{N}, 33^{\circ} 56^{\prime} 31^{\prime \prime} \mathrm{E} \quad 15 \mathrm{~m}$ $35^{\circ} 07^{\prime} 40^{\prime \prime} \mathrm{N}, 33^{\circ} 56^{\prime} 36^{\prime \prime} \mathrm{E} \quad 3 \mathrm{~m}$ $35^{\circ} 10^{\prime} 06^{\prime \prime} \mathrm{N}, 32^{\circ} 54^{\prime} 45^{\prime \prime} \mathrm{E} \quad 17 \mathrm{~m}$ $35^{\circ} 15^{\prime} 49^{\prime \prime} \mathrm{N}, 33^{\circ} 44^{\prime} 48^{\prime \prime} \mathrm{E} \quad 71 \mathrm{~m}$ $35^{\circ} 17^{\prime} 32^{\prime \prime} \mathrm{N}, 33^{\circ} 44^{\prime} 10^{\prime \prime} \mathrm{E} 117 \mathrm{~m}$ $35^{\circ} 20^{\prime} 08^{\prime \prime} \mathrm{N}, 33^{\circ} 04^{\prime} 06^{\prime \prime} \mathrm{E} \quad 37 \mathrm{~m}$ $35^{\circ} 21^{\prime} 09^{\prime \prime} \mathrm{N}, 33^{\circ} 04^{\prime} 28^{\prime \prime} \mathrm{E} \quad 54 \mathrm{~m}$ $35^{\circ} 28^{\prime} 21^{\prime \prime} \mathrm{N}, 34^{\circ} 09^{\prime} 04^{\prime \prime} \mathrm{E} \quad 135 \mathrm{~m}$ $35^{\circ} 07^{\prime} 57^{\prime \prime} \mathrm{N}, 32^{\circ} 50^{\prime} 08^{\prime \prime} \mathrm{E} \quad 25 \mathrm{~m}$ $35^{\circ} 20^{\prime} 23^{\prime \prime} \mathrm{N}, 33^{\circ} 18^{\prime} 58^{\prime \prime} \mathrm{E} \quad 12 \mathrm{~m}$ $35^{\circ} 20^{\prime} 10^{\prime \prime} \mathrm{N}, 33^{\circ} 18^{\prime} 29^{\prime \prime} \mathrm{E} \quad 29 \mathrm{~m}$ $35^{\circ} 17^{\prime} 26^{\prime \prime} \mathrm{N}, 33^{\circ} 13^{\prime} 01^{\prime}$ ' E $328 \mathrm{~m}$ 


\begin{tabular}{|c|c|c|}
\hline site name & coordinates & altitude \\
\hline 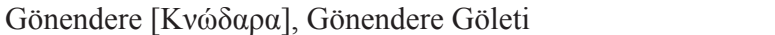 & $35^{\circ} 17^{\prime} 23^{\prime \prime} \mathrm{N}, 33^{\circ} 39^{\prime} 20^{\prime \prime} \mathrm{E}$ & $122 \mathrm{~m}$ \\
\hline Gönendere $[K v \omega ́ \delta \alpha \rho \alpha]$, south-western margin & $35^{\circ} 15^{\prime} 35^{\prime \prime} \mathrm{N}, 33^{\circ} 39^{\prime} 24^{\prime \prime} \mathrm{E}$ & $74 \mathrm{~m}$ \\
\hline 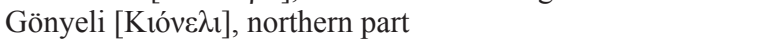 & $35^{\circ} 13^{\prime} 58^{\prime \prime} \mathrm{N}, 33^{\circ} 17^{\prime} 32^{\prime \prime} \mathrm{E}$ & $191 \mathrm{~m}$ \\
\hline Görneç [Корvóкплоธ], Yareselı mağara & $35^{\circ} 17^{\prime} 41^{\prime \prime} \mathrm{N}, 33^{\circ} 34^{\prime} 02^{\prime \prime} \mathrm{E}$ & $606 \mathrm{~m}$ \\
\hline 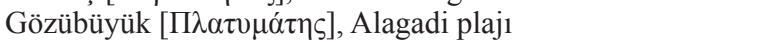 & $35^{\circ} 19^{\prime} 49^{\prime \prime} \mathrm{N}, 33^{\circ} 29^{\prime} 06^{\prime \prime} \mathrm{E}$ & $35 \mathrm{~m}$ \\
\hline 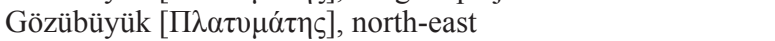 & $35^{\circ} 20^{\prime} 09^{\prime \prime} \mathrm{N}, 33^{\circ} 31^{\prime} 08^{\prime \prime} \mathrm{E}$ & $43 \mathrm{~m}$ \\
\hline 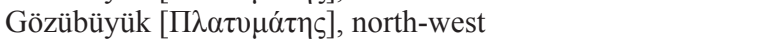 & $35^{\circ} 19^{\prime} 55^{\prime \prime} \mathrm{N}, 33^{\circ} 27^{\prime} 20^{\prime \prime} \mathrm{E}$ & $17 \mathrm{~m}$ \\
\hline 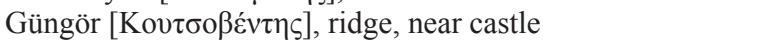 & $35^{\circ} 16^{\prime} 59^{\prime \prime} \mathrm{N}, 33^{\circ} 24^{\prime} 21^{\prime \prime} \mathrm{E}$ & $671 \mathrm{~m}$ \\
\hline 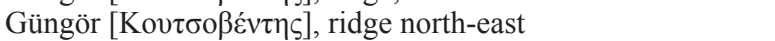 & $35^{\circ} 16^{\prime} 38^{\prime \prime} \mathrm{N}, 33^{\circ} 26^{\prime} 01^{\prime \prime} \mathrm{E}$ & $614 \mathrm{~m}$ \\
\hline Güzelyurt [Mópழov], town centre & $35^{\circ} 12^{\prime} 04^{\prime \prime} \mathrm{N}, 32^{\circ} 59^{\prime} 27^{\prime \prime} \mathrm{E}$ & $44 \mathrm{~m}$ \\
\hline 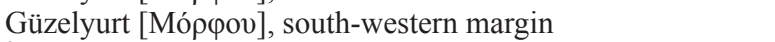 & $35^{\circ} 11^{\prime} 26^{\prime \prime} \mathrm{N}, 32^{\circ} 58^{\prime} 29^{\prime \prime} \mathrm{E}$ & $44 \mathrm{~m}$ \\
\hline 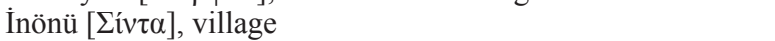 & $35^{\circ} 09^{\prime} 25^{\prime \prime} \mathrm{N}, 33^{\circ} 42^{\prime} 06^{\prime \prime} \mathrm{E}$ & $31 \mathrm{~m}$ \\
\hline 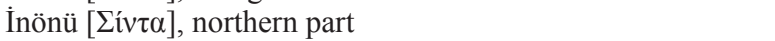 & $35^{\circ} 09^{\prime} 49^{\prime \prime} \mathrm{N}, 33^{\circ} 42^{\prime} 05^{\prime \prime} \mathrm{E}$ & $34 \mathrm{~m}$ \\
\hline 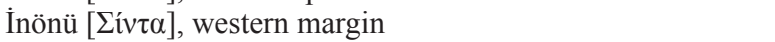 & $35^{\circ} 09^{\prime} 14 ” \mathrm{~N}, 33^{\circ} 41^{\prime} 32^{\prime \prime} \mathrm{E}$ & $35 \mathrm{~m}$ \\
\hline 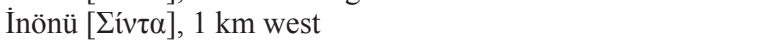 & $35^{\circ} 09^{\prime} 11^{\prime \prime} \mathrm{N}, 33^{\circ} 41^{\prime} 20^{\prime \prime} \mathrm{E}$ & $38 \mathrm{~m}$ \\
\hline 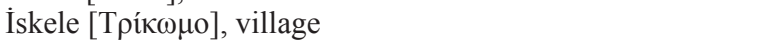 & $35^{\circ} 17^{\prime} 14^{\prime \prime} \mathrm{N}, 33^{\circ} 53^{\prime} 32^{\prime \prime} \mathrm{E}$ & $31 \mathrm{~m}$ \\
\hline 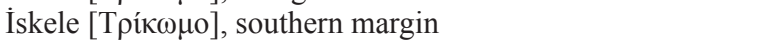 & $35^{\circ} 16^{\prime} 40^{\prime \prime} \mathrm{N}, 33^{\circ} 53^{\prime} 55^{\prime \prime} \mathrm{E}$ & $15 \mathrm{~m}$ \\
\hline 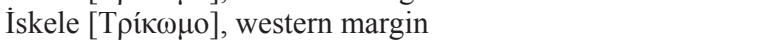 & $35^{\circ} 17^{\prime} 01^{\prime \prime} \mathrm{N}, 33^{\circ} 53^{\prime} 11^{\prime \prime} \mathrm{E}$ & $27 \mathrm{~m}$ \\
\hline 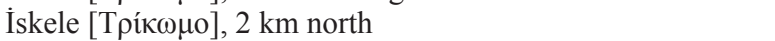 & $35^{\circ} 18^{\prime} 19^{\prime \prime} \mathrm{N}, 33^{\circ} 53^{\prime} 17^{\prime \prime} \mathrm{E}$ & $44 \mathrm{~m}$ \\
\hline 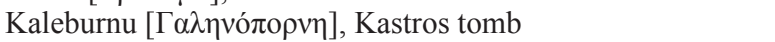 & $35^{\circ} 31^{\prime} 25^{\prime \prime} \mathrm{N}, 34^{\circ} 18^{\prime} 23^{\prime \prime} \mathrm{E}$ & $97 \mathrm{~m}$ \\
\hline Kaleburnu [Г $\alpha \lambda \eta v o ́ \pi о \rho v \eta]$, village & $35^{\circ} 31^{\prime} 25^{\prime \prime} \mathrm{N}, 34^{\circ} 18^{\prime} 02^{\prime \prime} \mathrm{E}$ & $93 \mathrm{~m}$ \\
\hline 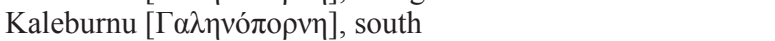 & $35^{\circ} 30^{\prime} 56^{\prime \prime} \mathrm{N}, 34^{\circ} 18^{\prime} 01^{\prime \prime} \mathrm{E}$ & $35 \mathrm{~m}$ \\
\hline 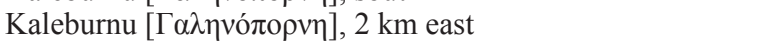 & $35^{\circ} 31^{\prime} 25^{\prime \prime} \mathrm{N}, 34^{\circ} 19^{\prime} 12^{\prime \prime} \mathrm{E}$ & $59 \mathrm{~m}$ \\
\hline 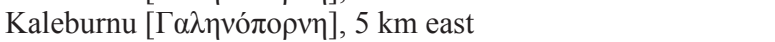 & $35^{\circ} 32^{\prime} 41^{\prime \prime} \mathrm{N}, 34^{\circ} 20^{\prime} 47^{\prime \prime} \mathrm{E}$ & $27 \mathrm{~m}$ \\
\hline 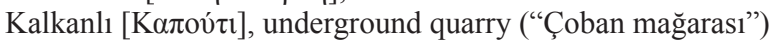 & $35^{\circ} 15^{\prime} 30^{\prime \prime} \mathrm{N}, 33^{\circ} 01^{\prime} 35^{\prime \prime} \mathrm{E}$ & $97 \mathrm{~m}$ \\
\hline 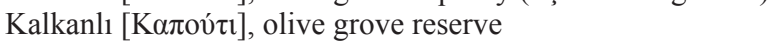 & $35^{\circ} 15^{\prime} 28^{\prime \prime} \mathrm{N}, 33^{\circ} 01^{\prime} 32^{\prime \prime} \mathrm{E}$ & $94 \mathrm{~m}$ \\
\hline 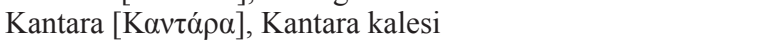 & $35^{\circ} 24^{\prime} 23^{\prime \prime} \mathrm{N}, 33^{\circ} 55^{\prime} 24^{\prime \prime} \mathrm{E}$ & $582 \mathrm{~m}$ \\
\hline 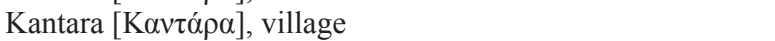 & $35^{\circ} 23^{\prime} 15^{\prime \prime} \mathrm{N}, 33^{\circ} 53^{\prime} 55^{\prime \prime} \mathrm{E}$ & $548 \mathrm{~m}$ \\
\hline Kaplica $[\Delta \alpha v \lambda$ ó $]$, north & $35^{\circ} 25^{\prime} 35^{\prime \prime} \mathrm{N}, 33^{\circ} 54^{\prime} 26^{\prime \prime} \mathrm{E}$ & $32 \mathrm{~m}$ \\
\hline 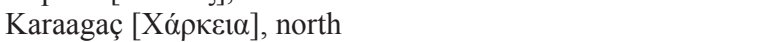 & $35^{\circ} 20^{\prime} 32^{\prime \prime} \mathrm{N}, 33^{\circ} 32^{\prime} 20^{\prime \prime} \mathrm{E}$ & $25 \mathrm{~m}$ \\
\hline 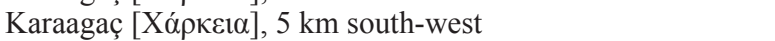 & $35^{\circ} 17^{\prime} 40^{\prime \prime} \mathrm{N}, 33^{\circ} 32^{\prime} 25^{\prime \prime} \mathrm{E}$ & $621 \mathrm{~m}$ \\
\hline Karakum [K $\alpha \rho \alpha ́ \kappa o v \mu 1]$, town centre & $35^{\circ} 19^{\prime} 49^{\prime \prime} \mathrm{N}, 33^{\circ} 21^{\prime} 39^{\prime \prime} \mathrm{E}$ & $24 \mathrm{~m}$ \\
\hline 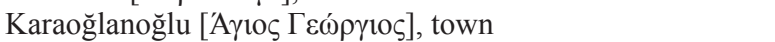 & $35^{\circ} 20^{\prime} 35^{\prime \prime} \mathrm{N}, 33^{\circ} 16^{\prime} 03^{\prime \prime} \mathrm{E}$ & $20 \mathrm{~m}$ \\
\hline Karşıyaka $[\mathrm{B} \alpha \sigma \iota \lambda \varepsilon 1 \alpha]$, village & $35^{\circ} 20^{\prime} 42^{\prime \prime} \mathrm{N}, 33^{\circ} 07^{\prime} 21^{\prime \prime} \mathrm{E}$ & $98 \mathrm{~m}$ \\
\hline Karşıyaka $[\mathrm{B} \alpha \sigma \iota \lambda \varepsilon ı \alpha]$, eastern margin & $35^{\circ} 20^{\prime} 52^{\prime \prime} \mathrm{N}, 33^{\circ} 08^{\prime} 30^{\prime \prime} \mathrm{E}$ & $46 \mathrm{~m}$ \\
\hline Karşıyaka $[\mathrm{B} \alpha \sigma \imath \lambda \varepsilon \imath \alpha]$, western margin & $35^{\circ} 20^{\prime} 59^{\prime \prime} \mathrm{N}, 33^{\circ} 05^{\prime} 04^{\prime \prime} \mathrm{E}$ & $8 \mathrm{~m}$ \\
\hline Karşıyaka $[\mathrm{B} \alpha \sigma \iota \lambda \varepsilon ı \alpha]$, western part & $35^{\circ} 20^{\prime} 58^{\prime \prime} \mathrm{N}, 33^{\circ} 06^{\prime} 38^{\prime \prime} \mathrm{E}$ & $70 \mathrm{~m}$ \\
\hline Karşıyaka [B $\alpha \sigma \imath \lambda \varepsilon 1 \alpha]$, road crossing & $35^{\circ} 19^{\prime} 38^{\prime \prime} \mathrm{N}, 33^{\circ} 06^{\prime} 55^{\prime \prime} \mathrm{E}$ & $407 \mathrm{~m}$ \\
\hline Kayalar ['O $\rho \gamma \alpha]$, village & $35^{\circ} 21^{\prime} 33^{\prime \prime} \mathrm{N}, 33^{\circ} 01^{\prime} 53^{\prime \prime} \mathrm{E}$ & $103 \mathrm{~m}$ \\
\hline Kayalar [O $\rho \gamma \alpha], 2 \mathrm{~km}$ east & $35^{\circ} 21^{\prime} 23^{\prime \prime} \mathrm{N}, 33^{\circ} 03^{\prime} 21^{\prime \prime} \mathrm{E}$ & $13 \mathrm{~m}$ \\
\hline 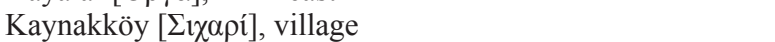 & $35^{\circ} 16^{\prime} 29^{\prime \prime} \mathrm{N}, 33^{\circ} 23^{\prime} 07^{\prime \prime} \mathrm{E}$ & $341 \mathrm{~m}$ \\
\hline 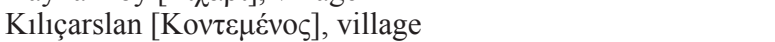 & $35^{\circ} 16^{\prime} 16^{\prime \prime} \mathrm{N}, 33^{\circ} 07^{\prime} 30^{\prime \prime} \mathrm{E}$ & $204 \mathrm{~m}$ \\
\hline 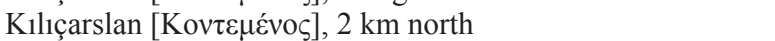 & $35^{\circ} 17^{\prime} 14^{\prime \prime} \mathrm{N}, 33^{\circ} 07^{\prime} 36^{\prime \prime} \mathrm{E}$ & $216 \mathrm{~m}$ \\
\hline 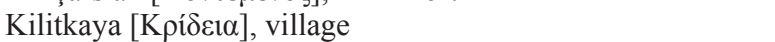 & $35^{\circ} 23^{\prime} 42^{\prime \prime} \mathrm{N}, 33^{\circ} 58^{\prime} 32^{\prime \prime} \mathrm{E}$ & $101 \mathrm{~m}$ \\
\hline 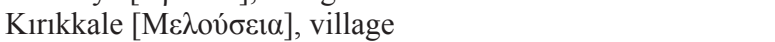 & $35^{\circ} 04^{\prime} 39^{\prime \prime} \mathrm{N}, 33^{\circ} 34^{\prime} 59^{\prime \prime} \mathrm{E}$ & $123 \mathrm{~m}$ \\
\hline 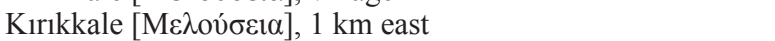 & $35^{\circ} 04^{\prime} 50^{\prime \prime} \mathrm{N}, 33^{\circ} 35^{\prime} 32^{\prime \prime} \mathrm{E}$ & $116 \mathrm{~m}$ \\
\hline Kirklar [Tú $\mu \beta \mathrm{ov}], 1 \mathrm{~km}$ east & $35^{\circ} 07^{\prime} 38^{\prime \prime} \mathrm{N}, 33^{\circ} 31^{\prime} 19^{\prime \prime} \mathrm{E}$ & $112 \mathrm{~m}$ \\
\hline Kirklar [Tú $\mu \beta$ ov] & $35^{\circ} 08^{\prime} 32^{\prime \prime} \mathrm{N}, 33^{\circ} 31^{\prime} 01^{\prime \prime} \mathrm{E}$ & $101 \mathrm{~m}$ \\
\hline Kirklar [Tú $\mu \beta$ ov], $1 \mathrm{~km}$ south & $35^{\circ} 07^{\prime} 09^{\prime \prime} \mathrm{N}, 33^{\circ} 30^{\prime} 08^{\prime \prime} \mathrm{E}$ & $119 \mathrm{~m}$ \\
\hline
\end{tabular}


Klepini [= Arapköy] and Pentadactylos [= Beşparmak], between

Kömürcü [Kıó

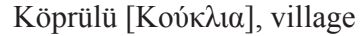

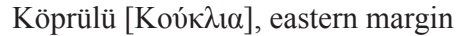

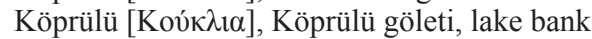

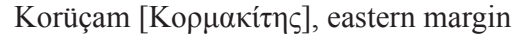

Kozan [ $\Lambda \alpha ́ p v \alpha \kappa \alpha \varsigma \tau \eta \varsigma \Lambda \alpha \pi \eta ́ \theta o v]$, slope 2 km north-west

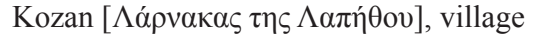

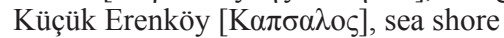

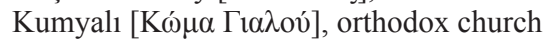

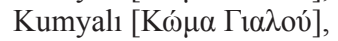
underground quarry ("Kumyalı mağarası")

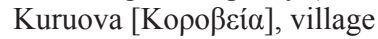

Kyrenia [= Girne] ... see Girne [Kepv́veı $\alpha$ ], downtown

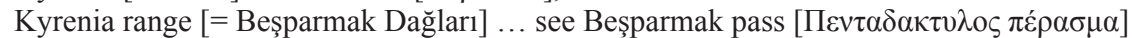

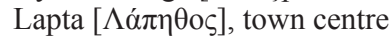

Lapta $[\Lambda \alpha ́ \pi \eta \theta$ os], water line gallery

Lapta [ $\Lambda \alpha ́ \pi \eta \theta$ os], abandoned house

Lapta $[\Lambda \alpha ́ \pi \eta \theta o \varsigma]$, western margin

Lapta $[\Lambda \alpha ́ \pi \eta \theta$ oc], western part

Lefke $[\Lambda \varepsilon v \kappa \alpha]$, Acendu, stream

Lefkoşa $[\Lambda \varepsilon v \kappa \omega \sigma i ́ \alpha]$, downtown

Lefkoşa $[\Lambda \varepsilon v \kappa \omega \sigma i ́ \alpha]$, eastern margin

Lefkoşa $[\Lambda \varepsilon v \kappa \omega \sigma i ́ \alpha]$, old town

Lefkoşa $[\Lambda \varepsilon v \kappa \omega \sigma i ́ \alpha]$, Göçmenköy

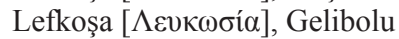

Lounata Springs [= Loumata Springs, south-east of Tatlisu]

Malatya [П $\alpha \lambda \alpha 10 \sigma o \varphi \circ \varsigma]$, mountain spring

Margo [M $\alpha \rho \gamma o ́]$, farm/barracks

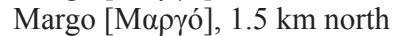

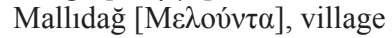

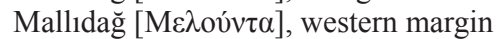

Mersinlik [ $\Phi \lambda \alpha \mu \circ v \delta \delta 1], 2 \mathrm{~km}$ north

Mersinlik [ $\Phi \lambda \alpha \mu \circ v ́ \delta 1], 5 \mathrm{~km}$ north-east

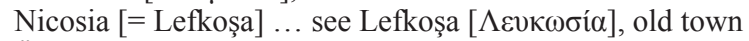

Ötüken [ $\Sigma \pi \alpha \theta \alpha \rho$ ı́ó], resort $6 \mathrm{~km}$ north-east

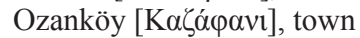

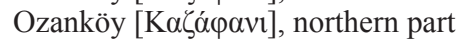

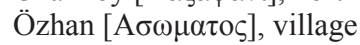

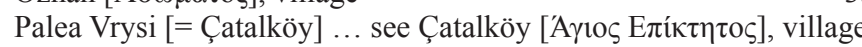

Pamuklu [Taúpos], village

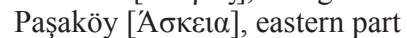

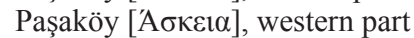

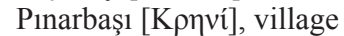

Pınarbaşı [K $\rho \eta v i ́]$, eastern margin

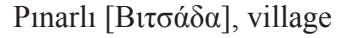

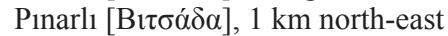

Sadrazamköy $[\Lambda 1 \beta \varepsilon \rho \alpha]$, water reservoir

Sadrazamköy $[\Lambda 1 \beta \varepsilon \rho \alpha]$, village $35^{\circ} 17^{\prime} 25^{\prime \prime} \mathrm{N}, 33^{\circ} 26^{\prime} 52^{\prime \prime}$ E $365 \mathrm{~m}$

$35^{\circ} 17^{\prime} 04^{\prime \prime} \mathrm{N}, 33^{\circ} 15^{\prime} 06^{\prime \prime}$ E $281 \mathrm{~m}$

$35^{\circ} 06^{\prime} 32^{\prime \prime} \mathrm{N}, 33^{\circ} 44^{\prime} 57^{\prime \prime} \mathrm{E} \quad 33 \mathrm{~m}$

$35^{\circ} 06^{\prime} 23^{\prime \prime} \mathrm{N}, 33^{\circ} 45^{\prime} 36^{\prime \prime} \mathrm{E} \quad 19 \mathrm{~m}$

$35^{\circ} 07^{\prime} 11^{\prime \prime} \mathrm{N}, 33^{\circ} 45^{\prime} 25^{\prime \prime} \mathrm{E} \quad 21 \mathrm{~m}$

$35^{\circ} 20^{\prime} 28^{\prime \prime} \mathrm{N}, 33^{\circ} 00^{\prime} 49^{\prime \prime} \mathrm{E} \quad 211 \mathrm{~m}$

$35^{\circ} 19^{\prime} 32^{\prime \prime}$ N, $33^{\circ} 06^{\prime} 58^{\prime \prime}$ E $405 \mathrm{~m}$

$35^{\circ} 18^{\prime} 49^{\prime \prime} \mathrm{N}, 33^{\circ} 08^{\prime} 32^{\prime \prime}$ E $349 \mathrm{~m}$

$35^{\circ} 21^{\prime} 27^{\prime \prime} \mathrm{N}, 33^{\circ} 38^{\prime} 57^{\prime \prime} \mathrm{E} \quad 32 \mathrm{~m}$

$35^{\circ} 25^{\prime} 47^{\prime \prime} \mathrm{N}, 34^{\circ} 08^{\prime} 10^{\prime \prime} \mathrm{E} \quad 31 \mathrm{~m}$

$35^{\circ} 26^{\prime} 24$ " N, 34 $10^{\prime} 09^{\prime \prime} \mathrm{E} \quad 12 \mathrm{~m}$

$35^{\circ} 30^{\prime} 41^{\prime \prime} \mathrm{N}, 34^{\circ} 16^{\prime} 22^{\prime \prime} \mathrm{E} \quad 83 \mathrm{~m}$

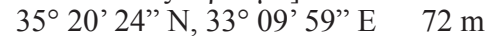

$35^{\circ} 20^{\prime} 18^{\prime \prime} \mathrm{N}, 33^{\circ} 10^{\prime} 32^{\prime \prime} \mathrm{E} \quad 96 \mathrm{~m}$

$35^{\circ} 20^{\prime} 19^{\prime \prime} \mathrm{N}, 33^{\circ} 10^{\prime} 32^{\prime \prime} \mathrm{E} \quad 86 \mathrm{~m}$

$35^{\circ} 20^{\prime} 48^{\prime \prime} \mathrm{N}, 33^{\circ} 09^{\prime} 14^{\prime \prime} \mathrm{E} \quad 30 \mathrm{~m}$

$35^{\circ} 20^{\prime} 48^{\prime \prime} \mathrm{N}, 33^{\circ} 09^{\prime} 44^{\prime \prime} \mathrm{E} \quad 24 \mathrm{~m}$

$35^{\circ} 06^{\prime} 59^{\prime \prime} \mathrm{N}, 32^{\circ} 51^{\prime} 21^{\prime \prime} \mathrm{E} \quad 84 \mathrm{~m}$

$35^{\circ} 10^{\prime} 57^{\prime \prime} \mathrm{N}, 33^{\circ} 21^{\prime} 28^{\prime \prime} \mathrm{E} 146 \mathrm{~m}$

$35^{\circ} 12^{\prime} 46^{\prime \prime} \mathrm{N}, 33^{\circ} 23^{\prime}$ '06" E $125 \mathrm{~m}$

$35^{\circ} 10^{\prime} 34^{\prime \prime} \mathrm{N}, 33^{\circ} 21^{\prime} 27^{\prime \prime}$ E $153 \mathrm{~m}$

$35^{\circ} 12^{\prime} 46^{\prime \prime} \mathrm{N}, 33^{\circ} 19^{\prime} 17^{\prime \prime} \mathrm{E} \quad 130 \mathrm{~m}$

$35^{\circ} 11$ ' $39^{\prime \prime} \mathrm{N}, 33^{\circ} 20^{\prime} 55^{\prime \prime} \mathrm{E} 132 \mathrm{~m}$

$35^{\circ} 22^{\prime} 11^{\prime \prime} \mathrm{N}, 33^{\circ} 45^{\prime} 54^{\prime \prime} \mathrm{E} 344 \mathrm{~m}$

$35^{\circ} 18^{\prime} 59^{\prime \prime} \mathrm{N}, 33^{\circ} 11^{\prime} 57^{\prime \prime} \mathrm{E} \quad 571 \mathrm{~m}$

$35^{\circ} 05^{\prime} 46^{\prime \prime} \mathrm{N}, 33^{\circ} 29^{\prime} 22^{\prime \prime}$ E $149 \mathrm{~m}$

$35^{\circ} 06^{\prime} 44^{\prime \prime} \mathrm{N}, 33^{\circ} 29^{\prime} 55^{\prime \prime} \mathrm{E} 127 \mathrm{~m}$

$35^{\circ} 20^{\prime} 00^{\prime \prime} \mathrm{N}, 33^{\circ} 41^{\prime} 21^{\prime \prime} \mathrm{E} \quad 315 \mathrm{~m}$

$35^{\circ} 19^{\prime} 51^{\prime \prime} \mathrm{N}, 33^{\circ} 41^{\prime} 08^{\prime \prime}$ E $313 \mathrm{~m}$

$35^{\circ} 24^{\prime} 41^{\prime \prime} \mathrm{N}, 33^{\circ} 51^{\prime} 10^{\prime \prime} \mathrm{E} \quad 36 \mathrm{~m}$

$35^{\circ} 24^{\prime} 56^{\prime \prime} \mathrm{N}, 33^{\circ} 52^{\prime} 20^{\prime \prime} \mathrm{E} \quad 38 \mathrm{~m}$

$35^{\circ} 15^{\prime} 11^{\prime \prime} \mathrm{N}, 33^{\circ} 54^{\prime} 14^{\prime \prime} \mathrm{E} \quad 3 \mathrm{~m}$

$35^{\circ} 19^{\prime} 00^{\prime \prime} \mathrm{N}, 33^{\circ} 20^{\prime} 45^{\prime \prime}$ E $104 \mathrm{~m}$

$35^{\circ} 19^{\prime} 47^{\prime \prime} \mathrm{N}, 33^{\circ} 22^{\prime} 07$ ' E $26 \mathrm{~m}$

$35^{\circ} 16^{\prime} 36^{\prime \prime} \mathrm{N}, 33^{\circ} 06^{\prime} 33^{\prime \prime} \mathrm{E} 197 \mathrm{~m}$

$35^{\circ} 23^{\prime} 44^{\prime \prime} \mathrm{N}, 34^{\circ} 04^{\prime} 35^{\prime \prime} \mathrm{E}$

$35^{\circ} 09^{\prime} 30^{\prime \prime} \mathrm{N}, 33^{\circ} 36^{\prime} 56^{\prime \prime} \mathrm{E}$

$35^{\circ} 09^{\prime} 34^{\prime \prime} \mathrm{N}, 33^{\circ} 35^{\prime} 56^{\prime \prime} \mathrm{E}$

$35^{\circ} 17^{\prime} 08^{\prime \prime} \mathrm{N}, 33^{\circ} 14^{\prime} 15^{\prime \prime} \mathrm{E}$

$35^{\circ} 17^{\prime} 05^{\prime \prime} \mathrm{N}, 33^{\circ} 14^{\prime} 56^{\prime \prime} \mathrm{E}$

$35^{\circ} 14^{\prime} 36^{\prime \prime} \mathrm{N}, 33^{\circ} 38^{\prime} 44^{\prime \prime} \mathrm{E}$

$35^{\circ} 15^{\prime} 03^{\prime \prime} \mathrm{N}, 33^{\circ} 39^{\prime} 06^{\prime \prime} \mathrm{E}$

$35^{\circ} 23^{\prime} 17^{\prime \prime} \mathrm{N}, 32^{\circ} 56^{\prime} 54^{\prime \prime} \mathrm{E}$

$35^{\circ} 22^{\prime} 55^{\prime \prime} \mathrm{N}, 32^{\circ} 57^{\prime} 27^{\prime \prime} \mathrm{E}$
$32 \mathrm{~m}$

$57 \mathrm{~m}$

$69 \mathrm{~m}$

$334 \mathrm{~m}$

$275 \mathrm{~m}$

$62 \mathrm{~m}$

$74 \mathrm{~m}$

$27 \mathrm{~m}$

$88 \mathrm{~m}$ 
Sadrazamköy $[\Lambda 1 \beta \varepsilon \rho \alpha], 4$ km east

Sazlıköy $[\Lambda 1 \beta \alpha ́ \delta ı]$, village

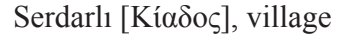

Serdarl $[K i \alpha \delta o c]$, southern margin

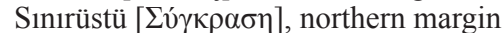

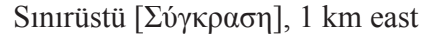

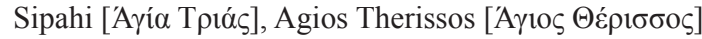

Sipahi ['Aүía Tpıós],

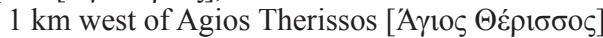

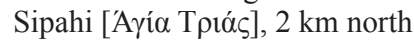

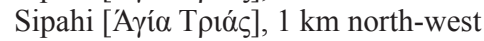

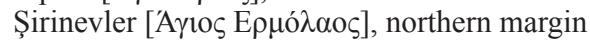

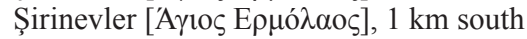

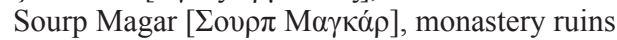

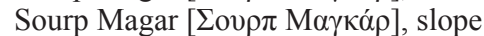

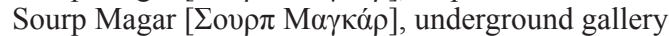

Sütlüce [ $\Psi v \lambda \lambda \alpha \dot{\alpha} \tau \sigma \varsigma]$, northern margin

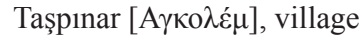

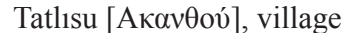

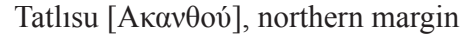

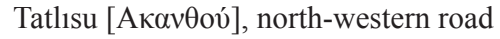

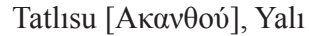

Tepebaşı [ $\Delta$ iópıoc], barracks

Tepebaş1 [ $\Delta$ iópı $\varsigma$ ], $3 \mathrm{~km}$ south

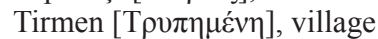

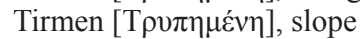

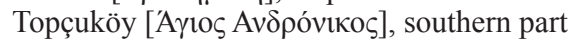

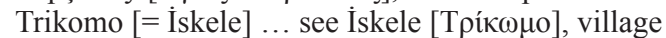

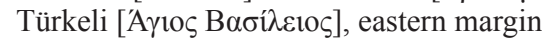

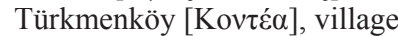

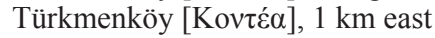

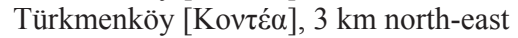

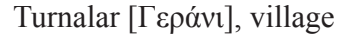

Ulukışla [M $\alpha \rho \alpha \theta$ óßovvos], village

Ulukışla [M $\alpha \rho \theta \theta$ óßovvos], 2 km north-east

Vadili [B $\alpha \tau \nu \lambda \eta ́]$, village

Vadili [B $\alpha \tau \nu \lambda \eta ́]$, north-western margin

Vadili [B $\alpha \tau \nu \lambda \eta ́], 2 \mathrm{~km}$ north-west

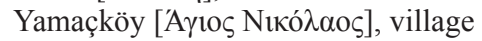

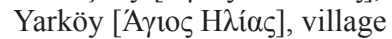

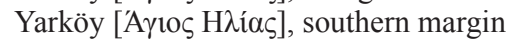

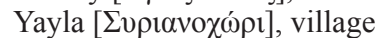

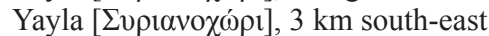

Yayla Tepe $[\Gamma 1 \alpha \lambda \lambda \alpha \varsigma]$, peak southern slope

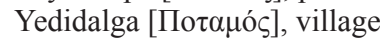

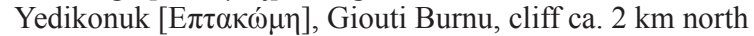

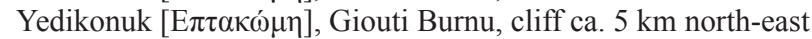

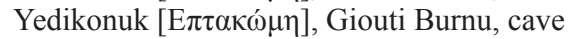

Yeni Erenköy [Гı $\alpha \lambda \circ v ́ \sigma \alpha]$, village $35^{\circ} 22^{\prime} 04^{\prime \prime} \mathrm{N}, 33^{\circ} 00^{\prime} 03^{\prime \prime} \mathrm{E} \quad 36 \mathrm{~m}$

$35^{\circ} 23^{\prime} 58^{\prime \prime} \mathrm{N}, 34^{\circ} 01$ ' $33^{\prime \prime} \mathrm{E} \quad 52 \mathrm{~m}$

$35^{\circ} 15^{\prime} 19^{\prime \prime} \mathrm{N}, 33^{\circ} 36^{\prime} 09^{\prime \prime} \mathrm{E} 114 \mathrm{~m}$

$35^{\circ} 14^{\prime} 47^{\prime \prime} \mathrm{N}, 33^{\circ} 36^{\prime} 28^{\prime \prime} \mathrm{E} \quad 89 \mathrm{~m}$

$35^{\circ} 16^{\prime} 35^{\prime \prime} \mathrm{N}, 33^{\circ} 51^{\prime} 07^{\prime \prime} \mathrm{E} \quad 32 \mathrm{~m}$

$35^{\circ} 16^{\prime} 38^{\prime \prime} \mathrm{N}, 33^{\circ} 51^{\prime} 40^{\prime \prime} \mathrm{E} \quad 29 \mathrm{~m}$

$35^{\circ} 34^{\prime} 10^{\prime \prime} \mathrm{N}, 34^{\circ} 15^{\prime} 25^{\prime \prime} \mathrm{E} \quad 7 \mathrm{~m}$

$35^{\circ} 33^{\prime} 56^{\prime \prime} \mathrm{N}, 34^{\circ} 14$ ' 53 ”' E $13 \mathrm{~m}$

$35^{\circ} 33^{\prime} 19^{\prime \prime} \mathrm{N}, 34^{\circ} 13^{\prime} 22^{\prime \prime} \mathrm{E} \quad 20 \mathrm{~m}$

$35^{\circ} 32^{\prime} 58^{\prime \prime} \mathrm{N}, 34^{\circ} 12^{\prime} 23^{\prime \prime} \mathrm{E} \quad 48 \mathrm{~m}$

$35^{\circ} 17^{\prime} 00^{\prime \prime} \mathrm{N}, 33^{\circ} 10^{\prime} 31^{\prime \prime} \mathrm{E} 258 \mathrm{~m}$

$35^{\circ} 15^{\prime} 55^{\prime \prime} \mathrm{N}, 33^{\circ} 10^{\prime} 03^{\prime \prime} \mathrm{E} 215 \mathrm{~m}$

$35^{\circ} 17^{\prime} 15^{\prime \prime} \mathrm{N}, 33^{\circ} 31^{\prime} 21^{\prime \prime} \mathrm{E} 523 \mathrm{~m}$

$35^{\circ} 17^{\prime} 12^{\prime \prime} \mathrm{N}, 33^{\circ} 31^{\prime} 00^{\prime \prime} \mathrm{E} \quad 623 \mathrm{~m}$

$35^{\circ} 17^{\prime} 16^{\prime \prime} \mathrm{N}, 33^{\circ} 31^{\prime} 21^{\prime \prime}$ E $518 \mathrm{~m}$

$35^{\circ} 15^{\prime} 25^{\prime \prime} \mathrm{N}, 33^{\circ} 41^{\prime} 07^{\prime \prime} \mathrm{E} \quad 61 \mathrm{~m}$

$35^{\circ} 07^{\prime} 13^{\prime \prime} \mathrm{N}, 32^{\circ} 56^{\prime} 48^{\prime \prime} \mathrm{E} \quad 121 \mathrm{~m}$

$35^{\circ} 22^{\prime} 38^{\prime \prime}$ N, $33^{\circ} 45^{\prime} 05^{\prime \prime}$ E $180 \mathrm{~m}$

$35^{\circ} 22^{\prime} 51^{\prime \prime} \mathrm{N}, 33^{\circ} 45^{\prime}$ '06” E $152 \mathrm{~m}$

$35^{\circ} 23^{\prime} 12^{\prime \prime} \mathrm{N}, 33^{\circ} 43^{\prime} 31^{\prime \prime} \mathrm{E} \quad 47 \mathrm{~m}$

$35^{\circ} 23^{\prime} 34^{\prime \prime} \mathrm{N}, 33^{\circ} 44^{\prime} 50^{\prime \prime} \mathrm{E} \quad 61 \mathrm{~m}$

$35^{\circ} 18^{\prime} 15^{\prime \prime} \mathrm{N}, 33^{\circ} 01^{\prime} 34^{\prime \prime} \mathrm{E} \quad 215 \mathrm{~m}$

$35^{\circ} 16^{\prime} 48^{\prime \prime} \mathrm{N}, 33^{\circ} 02^{\prime} 25^{\prime \prime} \mathrm{E} \quad 192 \mathrm{~m}$

$35^{\circ} 18^{\prime} 36^{\prime \prime} \mathrm{N}, 33^{\circ} 37^{\prime} 56^{\prime \prime} \mathrm{E} 226 \mathrm{~m}$

$35^{\circ} 19^{\prime} 05^{\prime \prime} \mathrm{N}, 33^{\circ} 37^{\prime} 22^{\prime \prime}$ E $344 \mathrm{~m}$

$35^{\circ} 19^{\prime} 48^{\prime \prime} \mathrm{N}, 33^{\circ} 52^{\prime} 36^{\prime \prime} \mathrm{E} 153 \mathrm{~m}$

$35^{\circ} 13^{\prime} 06^{\prime \prime} \mathrm{N}, 33^{\circ} 11^{\prime} 50^{\prime \prime} \mathrm{E} \quad 171 \mathrm{~m}$

$35^{\circ} 06^{\prime} 20^{\prime \prime} \mathrm{N}, 33^{\circ} 43^{\prime} 03^{\prime \prime} \mathrm{E} \quad 45 \mathrm{~m}$

$35^{\circ} 06^{\prime} 39^{\prime \prime} \mathrm{N}, 33^{\circ} 43$ ' 55” E $33 \mathrm{~m}$

$35^{\circ} 07^{\prime} 53^{\prime \prime} \mathrm{N}, 33^{\circ} 44^{\prime} 17^{\prime \prime} \mathrm{E} \quad 23 \mathrm{~m}$

$35^{\circ} 21$ ' $37^{\prime \prime} \mathrm{N}, 33^{\circ} 55^{\prime} 23$ " E $112 \mathrm{~m}$

$35^{\circ} 13^{\prime} 23^{\prime \prime}$ N, $33^{\circ} 37^{\prime} 04^{\prime \prime} \mathrm{E} \quad 65 \mathrm{~m}$

$35^{\circ} 14^{\prime} 02^{\prime \prime} \mathrm{N}, 33^{\circ} 38^{\prime} 11^{\prime \prime} \mathrm{E} \quad 60 \mathrm{~m}$

$35^{\circ} 08^{\prime} 08^{\prime \prime} \mathrm{N}, 33^{\circ} 39^{\prime} 26^{\prime \prime} \mathrm{E} \quad 52 \mathrm{~m}$

$35^{\circ} 08^{\prime} 30^{\prime \prime} \mathrm{N}, 33^{\circ} 38^{\prime} 50^{\prime \prime} \mathrm{E} \quad 54 \mathrm{~m}$

$35^{\circ} 08^{\prime} 50^{\prime \prime} \mathrm{N}, 33^{\circ} 38^{\prime} 17$ " E $57 \mathrm{~m}$

$35^{\circ} 19^{\prime} 44^{\prime \prime} \mathrm{N}, 33^{\circ} 40^{\prime} 39^{\prime \prime}$ E $305 \mathrm{~m}$

$35^{\circ} 19^{\prime} 37^{\prime \prime} \mathrm{N}, 33^{\circ} 55^{\prime} 47^{\prime}$ ' E $33 \mathrm{~m}$

$35^{\circ} 19^{\prime} 24^{\prime \prime} \mathrm{N}, 33^{\circ} 56^{\prime} 04^{\prime \prime} \mathrm{E} \quad 30 \mathrm{~m}$

$35^{\circ} 13^{\prime} 25^{\prime \prime} \mathrm{N}, 32^{\circ} 56^{\prime} 31^{\prime \prime} \mathrm{E} \quad 9 \mathrm{~m}$

$35^{\circ} 12^{\prime} 37^{\prime \prime} \mathrm{N}, 32^{\circ} 58^{\prime} 03^{\prime \prime} \mathrm{E} \quad 25 \mathrm{~m}$

$35^{\circ} 17^{\prime} 31^{\prime \prime} \mathrm{N}, 33^{\circ} 32^{\prime} 45^{\prime \prime} \mathrm{E} \quad 885 \mathrm{~m}$

$35^{\circ} 08^{\prime} 42^{\prime \prime} \mathrm{N}, 32^{\circ} 48^{\prime} 23^{\prime \prime} \mathrm{E} \quad 15 \mathrm{~m}$

$35^{\circ} 28^{\prime} 10^{\prime \prime} \mathrm{N}, 34^{\circ} 02^{\prime} 21^{\prime \prime} \mathrm{E} \quad 114 \mathrm{~m}$

$35^{\circ} 29^{\prime} 02^{\prime \prime} \mathrm{N}, 34^{\circ} 04^{\prime} 10^{\prime \prime} \mathrm{E} \quad 24 \mathrm{~m}$

$35^{\circ} 28^{\prime} 09^{\prime \prime} \mathrm{N}, 34^{\circ} 02^{\prime} 18^{\prime \prime} \mathrm{E} 108 \mathrm{~m}$

$35^{\circ} 32^{\prime} 08^{\prime \prime} \mathrm{N}, 34^{\circ} 11$ ' $24^{\prime \prime}$ E $117 \mathrm{~m}$ 


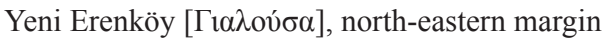

Yeni Erenköy [ $\Gamma \iota \lambda \lambda \circ v ́ \sigma \alpha]$, south-western margin

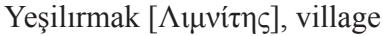

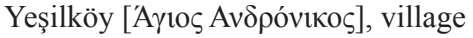

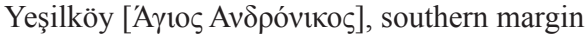

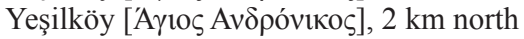

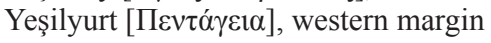

Yeşiltepe $[E \lambda(\alpha]$, town

Yiğitler [A

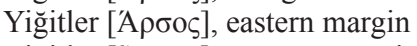

Yiğitler [A $А \sigma o \varsigma]$, western margin

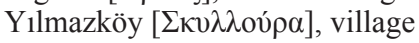

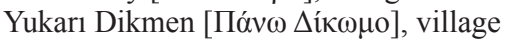

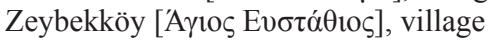

Zeytinlik [TÉ $\mu \pi \lambda \circ \varsigma]$, northern part

Ziyamet [ $\Lambda \varepsilon \omega v \alpha ́ \rho ı o]$, village $35^{\circ} 32^{\prime} 30^{\prime \prime} \mathrm{N}, 34^{\circ} 11^{\prime} 46^{\prime \prime} \mathrm{E} \quad 79 \mathrm{~m}$

$35^{\circ} 31^{\prime} 38^{\prime \prime} \mathrm{N}, 34^{\circ} 10^{\prime} 53^{\prime \prime} \mathrm{E} \quad 118 \mathrm{~m}$

$35^{\circ} 10^{\prime} 16^{\prime \prime} \mathrm{N}, 32^{\circ} 44^{\prime} 24$ " E $7 \mathrm{~m}$

$35^{\circ} 30^{\prime} 09^{\prime \prime} \mathrm{N}, 34^{\circ} 09^{\prime} 36^{\prime \prime} \mathrm{E} \quad 122 \mathrm{~m}$

$35^{\circ} 29^{\prime} 36^{\prime \prime} \mathrm{N}, 34^{\circ} 09^{\prime} 24^{\prime \prime} \mathrm{E} \quad 146 \mathrm{~m}$

$35^{\circ} 30^{\prime} 54^{\prime \prime} \mathrm{N}, 34^{\circ} 09^{\prime} 57^{\prime \prime}$ E $109 \mathrm{~m}$

$35^{\circ} 09^{\prime} 13^{\prime \prime} \mathrm{N}, 32^{\circ} 52^{\prime} 00^{\prime \prime} \mathrm{E} \quad 17 \mathrm{~m}$

$35^{\circ} 20^{\prime} 44^{\prime \prime} \mathrm{N}, 33^{\circ} 13^{\prime} 53^{\prime \prime} \mathrm{E} \quad 28 \mathrm{~m}$

$35^{\circ} 05^{\prime} 25^{\prime \prime} \mathrm{N}, 33^{\circ} 37^{\prime} 45^{\prime \prime} \mathrm{E} \quad 86 \mathrm{~m}$

$35^{\circ} 05^{\prime} 40^{\prime \prime} \mathrm{N}, 33^{\circ} 38^{\prime} 10^{\prime \prime} \mathrm{E} \quad 78 \mathrm{~m}$

$35^{\circ} 05^{\prime} 16^{\prime \prime} \mathrm{N}, 33^{\circ} 37$ ' 24 " E $93 \mathrm{~m}$

$35^{\circ} 14^{\prime} 01^{\prime \prime} \mathrm{N}, 33^{\circ} 09^{\prime} 49^{\prime \prime}$ E $161 \mathrm{~m}$

$35^{\circ} 16^{\prime} 24^{\prime \prime} \mathrm{N}, 33^{\circ} 18^{\prime} 39^{\prime \prime}$ E $233 \mathrm{~m}$

$35^{\circ} 23^{\prime} 21^{\prime \prime} \mathrm{N}, 34^{\circ} 00^{\prime} 51^{\prime \prime} \mathrm{E} \quad 55 \mathrm{~m}$

$35^{\circ} 20^{\prime} 22^{\prime \prime} \mathrm{N}, 33^{\circ} 17^{\prime} 54^{\prime \prime} \mathrm{E} \quad 22 \mathrm{~m}$

$35^{\circ} 28^{\prime} 09^{\prime \prime} \mathrm{N}, 34^{\circ} 08^{\prime} 19^{\prime \prime} \mathrm{E} 138 \mathrm{~m}$ 